NBER WORKING PAPER SERIES

\title{
COLLECTIVE ACTION BY CONTRACT: PRIOR APPROPRIATION AND THE DEVELOPMENT OF IRRIGATION IN THE WESTERN UNITED STATES
}

\author{
Bryan Leonard \\ Gary D. Libecap \\ Working Paper 22185 \\ http://www.nber.org/papers/w22185 \\ NATIONAL BUREAU OF ECONOMIC RESEARCH \\ 1050 Massachusetts Avenue \\ Cambridge, MA 02138 \\ April 2016, Revised April 2017
}

Previously circulated as "Economic Analysis of Property Rights: First Possession of Water in the American West." For helpful comments we thank Christopher Costello, Olivier Deschênes, Catherine Hafer, Lakshmi Iyer, Louis Kaplow, Dean Lueck, Steve Shavell, Henry Smith, Dick Startz and Jonathan Yoder as well as participants at workshops at the NBER DAE Summer Institute, the Political Institutions and Economic Policy Working Group, the Ostrom Workshop at Indiana University, UC Santa Barbara, Arizona State University, Columbia University, Harvard, UCLA, UC Irvine, Montana State University, the University of Arizona, Washington State University, Binghamton University, Carnegie Mellon University, the Society for Organizational and Institutional Economics, and the Western Economics Association. We also thank the Walton Family Foundation and the Sustainable Water Markets program at UC Santa Barbara for supporting this research. Excellent research assistance was provided by Cody Wilgas, Love Goyal, and A.J. Leon. The views expressed herein are those of the authors and do not necessarily reflect the views of the National Bureau of Economic Research.

NBER working papers are circulated for discussion and comment purposes. They have not been peerreviewed or been subject to the review by the NBER Board of Directors that accompanies official NBER publications.

(C) 2016 by Bryan Leonard and Gary D. Libecap. All rights reserved. Short sections of text, not to exceed two paragraphs, may be quoted without explicit permission provided that full credit, including (C) notice, is given to the source. 
Collective Action by Contract: Prior Appropriation and the Development of Irrigation in the Western United States Bryan Leonard and Gary D. Libecap

NBER Working Paper No. 22185

April 2016, Revised April 2017

JEL No. K11,N51,N52,Q15,Q25,Q28

\begin{abstract}
$\underline{\text { ABSTRACT }}$
We analyze the economic determinants and effects of prior appropriation water rights that were voluntarily implemented across an immense area of the US West, abruptly replacing commonlaw riparian water rights. At the same time and place, vast private irrigation infrastructure added to the US capital stock. We build upon Ostrom and Gardner (1993) and model irrigation as a coordination problem to show how prior appropriation facilitated greater private infrastructure development than was possible under the baseline riparian system by i) securing access to water against future entry and ii) defining a property right that formed the basis for contracting around collective action problems among numerous, heterogeneous agents. We construct a dataset of 7,800 rights in Colorado, established between 1852 and 2013 including location, date, size, infrastructure investment, irrigated acreage, crops, topography, stream flow, soil quality, and precipitation to test the predictions of the model. We find that prior appropriation facilitated cooperation, doubling infrastructure investment and ultimately contributing between $3 \%$ and $21 \%$ of western state income in 1930. These outcomes are relative to the baseline alternative of a riparian system. The analysis reveals institutional innovation that informs our understanding of the development of property rights, prior appropriation, and contemporary water policy.
\end{abstract}

\author{
Bryan Leonard \\ School of Sustainability \\ Arizona State University \\ and University of California, Santa Barbara \\ bryleonard@gmail.com \\ Gary D. Libecap \\ Bren School of Environmental Science \\ and Management and Economics Department \\ University of California, Santa Barbara \\ Bren Hall 4412 \\ Santa Barbara, CA 93106-5131 \\ and NBER \\ glibecap@bren.ucsb.edu
}




\section{Introduction}

Property rights are fundamental institutions for shaping economic behavior. When reasonably well defined, secure, and durable, they contribute to long-run economic growth (Acemoglu et al., 2001, 2005; Mehlum et al., 2006; Rodrik, 2008; Dixit, 2009; Besley and Ghatak, 2009), facilitate greater investment when returns are uncertain or delayed (Besley, 1995; Jacoby et al., 2002; Galiani and Schargrodsky, 2010; Lin et al., 2010), allow for the development of markets (Grief et al., 1994; Dixit, 2009; Edwards and Ogilvie, 2012), and reduce rent dissipation associated with common-pool resources (Gordon, 1954; Scott, 1955; Wiggins and Libecap, 1985; Gaudet et al., 2001; Wilen, 2005; Costello et al., 2008). ${ }^{1}$ Despite their importance, the determinants of how property rights initially emerge and how they facilitate coordination to overcome collective action problems have received little attention because voluntary major shifts in property institutions are rare, as are the data to analyze them. ${ }^{2}$ Nevertheless, once in place, property rights institutions endure, influencing markets and longterm economic outcomes (Libecap, 2007). Accordingly, positive analysis of the endogenous emergence of property rights reveals the underlying factors leading to their adoption and how they, in turn, allow for welfare-enhancing economic activities, not possible otherwise.

In this paper, we exploit the empirical setting of the westward settlement of the American frontier as a laboratory for institutional innovation and examine its economic characteristics. Settlers moved west across the continent after native claims had been swept aside. Migrants, seeking ownership of natural resources-land, timber, gold and silver-proceeded ahead of formal state and territorial governments, bringing with them basic legal norms, but confronting unfamiliar conditions that required new arrangements for successful economic growth (Anderson and Hill, 1975). These institutions appeared spontaneously via local contracting and persist today, molding contemporary markets and government policy.

Our focus is on the abrupt, deliberate shift from common-law riparian water rights that dominated in the eastern US and granted use of surface water to adjacent land holders based on contiguous acreage, to prior appropriation that assigned ownership of water based on time, as first-possession claims. ${ }^{3}$ Prior appropriation granted the right to divert a fixed amount of water for beneficial use at sites distant from a stream. Prior appropriation displaced riparian rights across an immense area of some 2,965,305 square miles (17 western states and 4 Canadian provinces), and was endorsed by federal and state law. ${ }^{4}$

\footnotetext{
${ }^{1}$ Because of transaction costs, property rights are never fully complete. The role of property rights in constraining rent dissipation in open-access resource has perhaps the largest literature. Other examples include Casey et al. (1995), Grafton et al. (2000), and Bohn and Deacon (2000).

2 Demsetz (1967), Cheung (1970), Anderson and Hill (1975), and Barzel (1997) emphasize that property rights emerge when the marginal benefit of creating, defining, and enforcing those rights exceed the marginal costs of doing so, but do not examine the forms property rights take in different settings or why.

${ }^{3}$ First-possession ownership of natural resources has been criticized for encouraging a race among homogeneous agents that dissipates rents (Barzel, 1968, 1994; Lueck, 1998). This argument does not account for the ubiquity of first possession or its economic contribution. Indeed, when agents and the resource are heterogeneous, dissipation is reduced (Lueck, 1995; Leonard and Libecap, 2015).

${ }^{4}$ Arizona, California, Colorado, Idaho, Kansas, Montana, Nebraska, Nevada, New Mexico, North Dakota, Oklahoma, Oregon, South Dakota, Texas, Utah, Washington, Wyoming, Alberta, British Columbia, Manitoba, and Saskatchewan (Scott, 2008, pp 101). Some of the less-arid jurisdictions have mixed systems of prior appropriation and riparian Mead $(1901,14,25)$. Prior appropriation is often characterized by the phrase, "first in time, first in
} 
Most prior appropriation rights were established between 1850 and 1920 when water was valued primarily as an input to irrigated agriculture, and today 40 to $80 \%$ of western water use remains in agriculture (Brewer et al., 2008). ${ }^{5}$ At the same time and place, vast private irrigation infrastructure added to the US capital stock. By 1920, \$697,657,328 $(\$ 823,236,000,000$ in 2015 $\$$ ) had been invested, mostly privately in 109,174 canals and ditches, 159,864 miles long, as well as in 7,538 dams and reservoirs with capacity of 21,246,436 acre feet (to scale, in 2016 California's massive, mostly government-invested surface storage was just under 50,000,000 acre feet). ${ }^{6}$ Figure 1 shows the wide range of irrigated acreage in agriculture as of 1920 due to development of water supply and delivery systems. The contemporaneous adoption of prior appropriation and new irrigation investment was not a coincidence; the new institutional structure was a necessary departure from existing systems of water rights.

Previous work has addressed why the riparian doctrine was not a feasible mechanism for allocating water in the West, but has failed to explain why prior appropriation emerged as the solution. ${ }^{7}$ We address this gap in the literature and draw broader lessons for understanding how property rights can be structured to address particular coordination problems. In this case, prior appropriation provided for relative security of water access in a semi-arid region that was not possible under a riparian system. It then facilitated coordination among individuals in their investment decisions to overcome the collective action problems associated with irrigation emphasized by Teele (1904), Coman (1911), Ostrom (2011), Libecap (2011), and Hanemann (2014).

Our examination of the economic benefits of prior appropriation suggests that it was adopted so broadly and quickly because it served as a basis for acquiring defined amounts of water for joint private investment and trade. Its advantages were relative to the baseline, incumbent riparian system. We do not make absolute efficiency claims for prior appropriation. Rather, we provide an economic explanation for its rapid emergence and persistence in the particular historical context of westward expansion. Our analysis clarifies the conditions under which new formal property rights can provide a comparative advantage over an existing system as well as how it may or may not blend with norm-based solutions to collective action problems emphasized by Ostrom (1990).

We present a model of contracting over irrigation investment to demonstrate how two key features of prior appropriation—quantification of water claims and priority-based

right." First possession in property rights allocation is discussed by Epstein (1978), Rose (1985, 1990), Ellickson (1993), and Lueck $(1995,1998)$. Pisani $(1992,2002)$ describes the development of prior appropriation water rights within an initial riparian setting and subsequent development of irrigation infrastructure and irrigated agriculture. ${ }^{5}$ Prior appropriation water rights have been described by many, including Burness and Quirk (1979, 1980a, b), Johnson et al., (1981), Smith (2000), Howe (2005), Hanemann (2014), and Chong and Sunding (2006). Kanazawa $(1996,2015)$ explores the early development of prior appropriation in mining camps, but it developed largely from demands for irrigation in the semi-arid region west of the 100th meridian. Ostrom (1953) and Ostrom and Ostrom (1972) discuss the replacement of riparian rights by prior appropriation.

${ }^{6}$ Calculated from $14^{\text {th }}$ US Census 1920, Vol VII Irrigation and Drainage (US Census Bureau, 1922, pp. 21, 41). California storage from http://waterinthewest.stanford.edu/groundwater/charts/capacity-comparison/index.html. Although the federal Reclamation Service was created in 1902, it took considerable time for its projects to begin and be completed. In 1913 the Census Bureau reported that there were no large federal irrigation/reclamation projects in operation (US Census Bureau, 1913, p. 831). CPI adjustment factor for commodities 1920 to 2015, 1180.

7 The prohibition of moving water away from source streams inherent in riparian water rights that protect downstream flows is a standard argument for prior appropriation in semi-arid regions (See Getches, 2009). As we describe, additional institutional innovation as provided by prior appropriation was required for irrigation investment to move water to remote sites and to trade it. 
allocation-made coordination possible for investment and exchange while securing these investments against the entry of new users. To test the predictions of the model we develop a data set that includes the location, date, and size of 7,800 water claims along with measures of infrastructure investment, irrigated acreage, crop choice, topography, stream flow, soil quality, precipitation, and drought in Colorado, the state where prior appropriation was most completely implemented initially. We examine individuals' decisions about where to establish a water right, whether to engage in cooperative behavior with other claimants, and how much to invest in irrigation infrastructure and then estimate changes in revenue associated with these decisions.

We find that i) individuals preferred to establish water claims near prior claimants, despite having potentially reduced access to water, suggesting large expected benefits from cooperation; ii) secure, recognized property rights facilitated coordination among large numbers of heterogeneous agents by reducing resource access uncertainty and providing an instrument for exchange; iii) coordination led to substantially higher levels of infrastructure investment, which led to iv) long-run increases in income per acre in agriculture.

We also show that the benefits of property rights were largest in areas that lacked informal institutions for coordinating individual investment behavior; these attributes were far less critical in areas where water users were in close-knit, small, older Hispanic communities and relied upon shared norms in farming and irrigation decisions. We also provide empirical estimates of the contribution of irrigated agriculture made possible by prior appropriation to economic development in the western US. We conclude by emphasizing that once prior appropriation was put into place, it provided an on-going framework for water allocation, use, and investment decisions. This framework remains today, channeling how contemporary water uses respond to new urbanization, environmental, and industrial demands. Our analysis extends the literatures on institutional change, property rights, first possession, and path dependency.

The paper proceeds as follows. Section 2 provides background on the development of prior appropriation and the economics of irrigation in the arid West. Section 3 presents a model of irrigation investment with testable predictions. Sections 4 and 5 describe the data used for our analysis and our empirical results on the determinants of claims and their economic implications, respectively. Section 6 concludes.

\section{Background}

\subsection{Water in the Semi-Arid West}

Prior to westward expansion, surface water rights in the United States primarily were allocated under the riparian doctrine. ${ }^{8}$ Riparian water rights are tied to the ownership of riparian lands; a potential claimant must own land adjacent to the surface water source they wish to use. At the same time, all owners of riparian land are granted "reasonable use" of surface waters adjacent to their property. Their use of water cannot excessively diminish surface flows to all other riparian owners. Riparian rights are not explicitly quantified and the only margin for formal exclusion of third parties is land ownership. Riparian rights cannot independently be transferred or traded, and during drought (which is rare in riparian areas) all owners are expected to reduce their use in a proportional manner, regardless of the timing or size of their initial use of the

\footnotetext{
${ }^{8}$ Rose (1990) discusses the early evolution of riparian water rights in the eastern United States.
} 
stream. This creates the need to monitor all users' diversions during drought to enforce reductions.

In contrast, the prior appropriation doctrine assigned rights via first possession, based on the timing of the initial claim. Construction of an irrigation ditch to divert a specific amount of water from a given location was sufficient to establish a claim, which could later be legally recognized in court. Appropriative rights were explicitly quantified and tied to a specific use in a specific location, though no riparian land ownership was required to claim water. The first-come, first-served allocation of appropriative rights also resulted in a priority-based system of allocation during drought, whereby senior claims had to be fully satisfied before junior users could divert any water. Priority access to water was defined by stream, so that being the first claimant on a given watercourse granted the highest priority to water in any given year.

Critically, the priority system protected prior diversion amounts from being diminished by subsequent water claimants on a stream. ${ }^{9}$ The appropriative system also reduced monitoring costs relative to a riparian system because only juniors who have a "call" placed on their water, releasing it to seniors, need to be monitored.

Figure 2 shows the distribution of major streams and the change in property rights regimes for water that occurred in jurisdictions west of the 100th meridian. The figure shows states/territories with either riparian rights or prior appropriation or hybrids of both. The dates indicate key constitutional, legislative, or judicial adoption of prior appropriation in each state. ${ }^{10}$ As the figure indicates, populations in states with abundant water resources held to the riparian doctrine; those in states with both dry and wet regions maintained mixed systems; and those in the most arid states with lower stream density rapidly adopted prior appropriation. Prior appropriation emerged over a 40-year period, whereby more formal rights and supporting institutions were adopted as competition for water increased (Demsetz, 1967). Because the native population had been displaced and the federal government was remote, early migrants had a relatively open slate to define property institutions to frontier resources.

To better understand the economic factors that led to the rise of prior appropriation, we focus on Colorado - the place where settlers in the westward movement of the agricultural frontier first encountered semi-arid terrain in a territory not dominated by preexisting riparian water rights holders. Colorado also exhibits many of the initial conditions facing migrants to the region prior to construction of large Bureau of Reclamation projects after the Reclamation Act of 1902. Finally, Colorado played a disproportionate role in influencing prior appropriation water

\footnotetext{
9 Early on, enforcement of diversion priority was a problem as late comers established claims upstream, diminishing flows available to more senior claims. For discussion of conflict and resolution see Boyd (1890) and Dunbar (1950).

${ }^{10}$ Mead (1901, p. 7-15) discusses the imperative to shifting from riparian to prior appropriation to promote irrigation in semi-arid regions. Dates of prior appropriation adoption: Arizona: Territory Arizona, Howell Territorial Code, Ch. LV, Hutchins (1977, p. 170); Colorado: Constitution art. XVI $§ 5$ and 6; Coffin v. Left Hand Ditch Co (6 Colo 443); Idaho: An Act to Regulate the Right to the Use of Water for Mining, Agriculture, Manufacturing, and Other Purposes (1881), Hutchins (1977, p. 170); Montana: Mettler v. Ames Realty Co., 61 Mont. 152, 170-171, 201 Pac. 702, MacIntyre (1994, p. 307-8); New Mexico: Territorial Constitution Art XVI § 2; Hutchins (1977, p. 228); Nevada: Lobdell v. Simpson, 2 Nev. 274, 277, 278; Hutchins (1977, p. 170-171); Utah: Utah Laws 1880, ch. XX; Wyoming: Constitution Art VIII §1-5; Hutchins (1977, p. 300); California: Irwin v. Phillips, 5 Cal. 40 (1855); Hutchins (1977, p. 181, 233-34); Kansas: 1886 Kans. Sess. Laws 154, ch. 115; Hutchins (1977, p. 170); Nebraska: Neb. Laws p. 168(1877); Hutchins (1977, p. 212); North Dakota: Terr. Dak. Laws 1881, ch. 142; Hutchins (1977, p. 213); Oklahoma: Terr. Okla. Laws 1897, ch. 19; Hutchins (1977, p. 171, 215); Oregon: Oregon Laws 1909, Ch. 216. Oregon Revised Stat. ch. 539; Hutchins (1977, p. 170); South Dakota: Terr. Dak. Laws 1881, ch. 142; Hutchins (1977, p. 170, 220); Texas: Tex. Gen. Laws 1889, ch. 88; Hutchins (1977, p. 170); Washington: Wash. Sess. Laws 1889-1890, p. 706; Sess. Laws 1891, ch. CXLII, Hutchins (1977, p. 170).
} 
rights development and enforcement in other states with what became "The Colorado Doctrine" (Colorado Water Institute, ND, p. 1; Boyd, 1890, p. 136; Mead, 1901, p. 14; US Census Bureau, 1913, p. 844; Hess, 1916, pp. 652-6; Hemphill, 1922, pp. 15-8; Dunbar, 1950, 1983, 1985;

Hobbs, 1997; Schorr, 2005; Stenzel and Cech, 2013, p. 223). ${ }^{11}$

The first Colorado Territorial Legislature in 1861 enacted legislation as a precursor to prior appropriation, allowing water to be diverted from streams to remote locations, abrogating common-law riparian principles that kept water on adjacent lands. An 1862 statute continued the move toward prior appropriation by granting right-of-way to irrigation ditch owners. An 1864 law emphasized the priority of diversion rights over riparian, and an important 1872 Colorado Supreme Court decision in Yunker v Nichols (1 Colo 552) sided with the priority rights holder against riparian diversions that depleted prior appropriation irrigation ditch water as an enforcement ruling.

In 1876 the Colorado Constitution formally proclaimed prior appropriation as the basis for water rights in the state. Statutes in 1879 and 1881 added administrative structures for adjudication of water rights, measurement, monitoring, dispute resolution, and enforcement. The state was divided into 10 water districts with local water commissioners and water courts to determine and enforce priority. The districts were grouped within 3 geographic water divisions. A key problem was to reduce the incentive of some parties to locate new claims upstream and illegally divert water from senior diverters downstream. Additionally, the allocation rules within ditch companies and irrigation districts were to be enforced by ditch riders and the by state (Boyd, 1890, 120-24; Dunbar, 1950, 241-61). A state Hydrologic Engineer's Office was created and county clerks were to record and define priority for appropriative claims that previously had been announced informally at diversion sites (Stenzel and Cech, 2013, pp. 188-215).

Finally, in 1882 the Colorado Supreme Court in Coffin v Left Hand Ditch Co(6 Colo 443) rejected remnants of riparianism in favor of prior appropriation (Colorado Water Institute ND, pp. 3-8; Dunbar, 1950, pp. 245-60; Hobbs, 1997, pp. 6-10, 31-2; Romero, 2002, pp. 536-9). As a result of all of this, the US Census Bureau in 1913 (p. 844) concluded that Colorado had by far the most well-defined water rights system among western states. This legal infrastructure provided for the official designation and enforcement of private water rights necessary for use and for pooling in joint investment in irrigation capital and trade.

Figure 3 depicts water and land resources as well as the current 7 geographic Water Divisions in Colorado. Colorado covers an area of some 66,620,160 acres containing over 107,000 miles of streams with elevations ranging from 3,317 to 14,440 feet. $^{12}$ Figure 4 shows the evolution of water claims in Colorado over time and indicates that claimants arrived in waves, primarily in the latter half of the 19th century. Colorado migrants came primarily from the northeast and north-central US where there was little need for irrigation and riparian rights had dominated (Colorado Water Institute, ND, 2; Dunbar, 1950, p. 242; Hobbs, 1997, p. 3; Romero, 2002, p. 527). The population of Colorado jumped sharply from 39,864 in 1870 to 539,700

\footnotetext{
${ }^{11}$ Prior appropriation first emerged in Colorado as a full tangible property right to water and became known as the Colorado Doctrine. It was a general template for other western territories and states and, generally, western Canadian provinces. Only in the wetter states of California, Oregon, and Washington did remnants of riparian water rights remain (Scott, 2008, p. 101).

${ }^{12}$ The 1900 population of Colorado was 539,700, implying a population density of 1 person per 123 acres.
} 
people by 1900 , fueled by migration into the farming regions east of the Rocky Mountains. ${ }^{13}$ Romero (2002, p. 527) notes what a diverse lot they were. The heterogeneity of migrants is demonstrated not only by the varied regions in the US from which they came, but also by the large share of foreign-born individuals. For example, in 1880, 20.5\% of the state's population came from abroad (Gibson and Jung, 2006, Table 14). These migrants confronted semi-arid conditions not found in the East or Western Europe and irrigation of crop lands and investment in conveyance capital to move water to distant sites were required (Powell, 1879). Large numbers, differences in background and origin, as well as limited information about water diversion sites, appropriate farming techniques, and irrigated agriculture raised the costs of organizing collective responses to these new conditions. Key to lowering organization costs was institutional innovation in water rights.

\subsection{Irrigation Economics}

The economic problem of irrigation in the American West centered around the development of infrastructure, including dams, reservoirs, canals, and feeder ditches to capture, store, and deliver the right amount of water for distant arable land. Mead (1901, p. 8) estimated that private irrigation systems valued nearly at $\$ 200,000,000(\$ 5,750,000,000$ in 2015 dollars) were in place as of 1901 in the western United States, prior to the enormous irrigation projects of the federal Reclamation Service. He also describes the complexity of raising capital and the coordination and consolidation among irrigation companies in the Cache La Poudre Valley, one of the first areas in Colorado to be placed under large-scale irrigation. ${ }^{14}$ Adams (1910, pp. 37-41) describes the intricate networks of irrigation infrastructure in the West, including along the Cache La Poudre, where the North Poudre Canal was 25 miles long with 140 miles of lateral ditches, drawing from 20 reservoirs to irrigate 27,500 acres. There were 500 irrigators and stock holders in the canal company. In this setting, separating water claims from land rights was a necessary, but not a sufficient condition for bringing water to valuable arable lands in the face of the irrigation investment requirement.

While the need to separate water and land claims explains why the explicitly land-based riparian system was inadequate for the West, it does little to clarify the economic advantages of prior appropriation itself. Why was first possession the natural alternative to a riparian land share-based system? And why create a priority-based system for allocating water rights rather than a proportional one? Contemporary policymakers repeatedly ask exactly these questions as they confront water allocation challenges associated with the appropriative doctrine which endure to this day-understanding why prior appropriation emerged in the first place is a critical first step in understanding the role of prior appropriation in adapting to the evolving challenges of water use in the West today.

Hanemann (2014) argues that western irrigation was characterized by high fixed costs of investment in non-deployable capital with low marginal costs of water transport. Large canals and ditches had to be constructed to move water from the rugged riparian corridor to productive

\footnotetext{
${ }^{13}$ https://www.census.gov/dmd/www/resapport/states/colorado.pdf. https://www.colorado.gov/pacific/archives/census-records-0.

${ }^{14}$ In the late 19th and early 20th centuries there were numerous investigations into irrigation in the western United States including Newell (1894), Mead (1901), and Adams (1910). Newell (1894) reports irrigation system values of $\$ 94,412,000$ in 1890 in 11 western states $(\$ 2,540,000,000$ in 2015. https://www.measuringworth.com/uscompare/relativevalue.php). He also reports data on differences in ditch construction costs according to ditch width.
} 
agricultural lands, but ditches-once constructed-were relatively cheap to use and maintain. The high fixed costs and capital intensity of ditch construction, combined with the delayed nature of income from agricultural investment, created a liquidity problem for farmers, often migrants who lacked significant assets. Credit markets were not readily available to overcome this liquidity problem for financing large-scale irrigation works to be used by many small farmers under uncertain conditions arising from agricultural production in new areas using new techniques.

As Coman (1911), Ostrom (2011), and Hanemann (2014) point out, the ability to share diversion capacity in large main ditches, coupled with individual credit constraints, made irrigation a classic collective action problem. Construction of these large ditches required coordination between large numbers of heterogeneous individuals who arrived in the West across several decades - settlers individually lacked the assets to finance ditch construction, but could potentially pool their resources to construct large ditches, often as mutual ditch companies owned by the local investors. ${ }^{15}$ The problem facing individuals was both how to secure a defined amount of water for diversion, not vulnerable to later riparian water claims and how to ensure cooperative behavior once the ditch was constructed. Early potential contributors faced uncertainty both about the amount of long-term water available for diversion through a ditch and about the extent to which the ditch could be used by additional irrigators, who arrived later. This new entry problem was exacerbated by the fact that land claims were generally allocated in small, 160-acre increments under the Homestead and other Acts, creating the potential for a massive number of potential claimants along a stream and in the service area for a given ditch.

Figure 5 illustrates the contracting problem facing potential irrigators and investors in costly irrigation infrastructure under a riparian system along a stream. The figure shows the stylized potential for 160-acre homestead claims possible along the Cache La Poudre River. ${ }^{16}$ The figure also shows actual major canal and ditch investments. The only ways upstream infrastructure investors could have proceeded under a riparian system was to claim ownership of all other riparian lands, an action blocked by the federal land laws, or to contract with all subsequent riparian claimants to secure their water. This action would have entailed extremely high bargaining costs.

We argue that the distinguishing features of prior appropriation-quantification and priority-based allocation-helped overcome the collective action problems outlined above. Explicit enumeration of individual claims under prior appropriation provided a basis for contracting that was lacking in unquantified, adjacent land share-based riparian rights. Moreover, the priority-based allocation of water under prior appropriation made incumbent users secure against future entry and related riparian water claims along the stream. This had three important implications. First, early users would have been more willing to engage in risky investment because their claims could not be dissipated by ensuing claimants. Second, assigning priority to earlier rights would have made senior users more willing to contract with new claimants within a ditch's potential service area, perhaps even leading them to invest in anticipation of subsequent waves of water users. Third, priority rights holders would have been able to trade water rights to consolidate diversion amounts, particularly critical as new information was revealed regarding stream flow variability as well as the location of new, productive distant farm land.

\footnotetext{
${ }^{15}$ Alternatively, more distant private investors could file for water rights and then form commercial ditch companies to deliver water to irrigators via water delivery contracts (Mead, 1901, 15, Appendix; Rettig, 2012, p. 3).

${ }^{16}$ To make the figure clearer full 640-acre sections are shown, when homestead claims were 160 acres or less. Moreover, there were also state and railroad sections granted by the federal government.
} 
These important functions of the appropriative system have been largely overlooked by economists, who have tended to focus on the disadvanatages of the priority system. Efficiency losses associated with prior appropriation are well understood (Burness and Quirk, 1979; Chong and Sunding, 2006; Brewer et al., 2008), but to date economists lack a positive economic explanation for the emergence of this system of property rights that shapes western water use. We fill this gap by offering a positive theory for the emergence of prior appropriation as a mechanism to solve collective action problems not feasible under the incumbent property system. In the next section we present a simple model of investment in irrigation infrastructure and derive testable predictions about how the structure of appropriative rights affects individuals' investment decisions.

\section{A Model of Coordinated Irrigation Investment}

\subsection{Model}

We generalize the simple model of irrigators in an asymmetric commons from Ostrom and Gardner (1993) to show how prior appropriation formed a basis for cooperation to develop irrigation infrastructure in the absence other coordinating institutions. We make several extensions to their model. First, we add a fixed cost so that irrigators cannot profitably invest in infrastructure without cooperating, consistent with the high fixed costs and credit constraints emphasized by Hanemann (2014). Second, we treat the model as a two-stage game with ditch investment in the first stage and water delivery to the ditch in the second stage, highlighting the credible commitment problem. Third, we allow water deliveries to the ditch in the second stage to be uncertain to reflect the threat of new entry on a stream. Fourth, we consider the full menu of possible contracts over investment and water deliveries. Fifth, we extend the model to $N$ players to analyze how group size affects the benefits of coordination. Throughout we assume that all players have perfect information.

Consider two irrigators, denoted player 1 and player 2, who must decide whether to jointly construct irrigation works. Investment decisions are made in the first period and water is delivered in the second period. Following Ostrom and Gardner's emphasis on asymmetry, we assume that player 1 (the "head-ender") can access the water before it reaches player 2 (the "tailender") during the second stage when water is delivered. The delivery of water depends on the investments of both users in the first stage. With the inclusion of a fixed cost equal to 1 that reflects minimum flow requirements to move water from the stream to distant fields, the

production function for water from Ostrom and Gardner is $W-1=2\left(x_{1}^{1 / 2}+x_{2}^{1 / 2}\right)-1$ where $x_{1}$ and $x_{2}$ are the investment contributions of players 1 and 2, respectively. We normalize the price of water to 1 .

In the absence of formal property rights, the threat of additional claimants on the stream reduces the probability that the players receive water to their ditch. Denote the probability of water delivery, given the threat of entry, as $\delta$. Regardless of how the internal coordination problem within a ditch is solved, there is always the possibility that additional users arrive on stream and under a riparian system claim water access, reducing actual flow to the ditch. The higher is $\delta$, the more secure are deliveries to the ditch. Expected water available for irrigation is $\delta W-1$-reflecting a certain fixed cost whether or not deliveries exceed what can be thought of as a minimum flow constraint.

The expected payoff for either individual acting alone is given by 


$$
U_{i}^{0}=\delta\left(2 x_{i}^{\frac{1}{2}}\right)-1-x_{i}
$$

which has as its solution $x_{i}^{*}=\delta^{2}$ and $U_{i}^{0}(1)=\delta^{2}-1 \leq 0$-when individuals act alone they cannot profitably build large enough irrigation works to deliver sufficient water for remote agricultural development. This reflects the high capital costs associated with irrigation infrastructure and underscores the need for joint action by irrigators. If individuals act jointly to produce $\delta W-1$ units of expected water, they must share that output. Suppose player 1's share is given by $\theta \in[0,1]$ so that player 1 gets $\theta(\delta W-1)$ expected units of water and player 2 gets $(1-\theta) \delta(W-1)$ expected units of water in the second stage. Ostrom and Gardner (1993) consider the coordination problem that arises for different exogenously given values of $\theta$ (e.g. $.75, .5$, etc.), meant to reflect player 1 's prior access to the water due to being closer to the head of the ditch. Our interest is in formally characterizing whether the players could agree on a sharing rule $\theta$ that makes both of them better off than with uncoordinated investment.

If individuals act together to maximize the expected joint surplus they solve:

$$
\max _{x_{1}, x_{2}} \delta 2\left(x_{1}^{1 / 2}+x_{2}^{1 / 2}\right)-1-x_{1}-x_{2}
$$

which has as its solution $x_{1}^{*}=x_{2}^{*}=\delta^{2}$, resulting in total expected water deliveries (net of the fixed flow) of $4 \delta^{2}-1$; individuals acting together to transport water via a ditch to their respective fields can make more water available by pooling their investments than by building two separate ditches, where both would have to overcome the capital investment problem separately.

Next we consider the set of contracts $\left\{\theta, x_{1}, x_{2}\right\}$ that result in the efficient outcome and then determine how these contracts can be enforced under different institutional settings. Contracts over $\theta$ must make both players better off than if they choose not to invest (or equivalently, to invest alone and earn 0 ), which allows us to bound the set of possible values for $\theta$ to achieve an efficient contract requiring optimal investment inputs from each player:

$$
\begin{aligned}
\theta \delta W\left(x_{1}^{*}, x_{2}^{*}\right)-x_{1}^{*} & =\theta\left(4 \delta^{2}-1\right)-\delta^{2}>0 \\
(1-\theta) \delta W\left(x_{1}^{*}, x_{2}^{*}\right)-x_{2}^{*} & =(1-\theta)\left(4 \delta^{2}-1\right)-\delta^{2}>0
\end{aligned}
$$

In order for both players to weakly prefer the contract to sole investment, it must be that $\theta \in$ $\left[\frac{\delta^{2}}{4 \delta^{2}-1}, 1-\frac{\delta^{2}}{4 \delta^{2}-1}\right]$. Hence, the set of welfare-maximizing contracts is characterized by $\left\{\left[\frac{\delta^{2}}{4 \delta^{2}-1}, 1-\frac{\delta^{2}}{4 \delta^{2}-1}\right], \delta^{2}, \delta^{2}\right\}$. In the absence of defined property rights to water, this contract is not an equilibrium due to multiple coordination failures.

The first coordination failure concerns contributions to the ditch. For a given sharing rule, each player has incentive to provide less than the optimal level of investment. If each player takes the sharing rule $\theta$ as given and chooses their investment to maximize solely their own profit, the dominant strategies are $x_{1}^{*}=\theta^{2} \delta^{2}$ and $x_{2}^{*}=(1-\theta)^{2} \delta^{2}$, which are both strictly less than the optimal investment input for water delivery associated with $\delta^{2}$. Without coordination to agree on joint investment levels, aggregate investment is too low and there is no sharing rule $\theta$ 
that satisfies the incentive compatiability constraints for both players. ${ }^{17}$ Hence, a contractual solution to the coordination problem must specify not only the sharing rule, but also dictate a level of investment from each player that exceeds their privately chosen level. If this shirking problem is not solved, investment will not occur.

The second coordination failure that prevents a cooperative equilibrium concerns the behavior of player 1 in the second stage. If the contract lacks enforcement for water delivery (as is the case without prior appropriation) in the second stage player 1 is able to choose any $\theta \in$ $[0,1]$, after investment decisions have been made. Clearly, the dominant strategy for player 1 is to set $\theta=1$, resulting in an expected payoff of $4 \delta^{2}-1-\delta^{2}=3 \delta^{2}-1$ for player 1 and $0-$ $\delta^{2}=-\delta^{2}$ for player 2 . Hence, in a two-stage game where players invest first and receive water in stage 2 , no contract is be incentive compatible for player 2 because any contribution from player 2 earns a negative expected payoff due to player 1's anticipated deviation from the agreed upon $\theta$ once investment has taken place. This is opportunism when capital is not deployable (Williamson, 1993).

The problem is one of credible commitment. Even though player 1 would be better off with a cooperative contract than without, it is not possible to credibly convince player 2 that post-contractual opportunism will not take place once irrigation works are constructed. The cooperative payoff is higher than the equilibrium non-cooperative outcome, so player 1 would gladly constrain the set of possible strategies in period 2 in order to elicit player 2's investment contribution. Moreover, both players would commit themselves to higher levels of investment than their equilibrium strategies if cooperation by both players could be guaranteed. That is, the players could achieve the first-best outcome if they had some mechanism to enforce the contract $\left\{\left[\frac{\delta^{2}}{4 \delta^{2}-1}, 1-\frac{\delta^{2}}{4 \delta^{2}-1}\right], \delta^{2}, \delta^{2}\right\}$, but in the absence of this contract investment does not occur and so both earn zero due to the lack of coordination.

Ostrom and Gardner (1993), Ostrom (2011), and others emphasize the need for trust to overcome this problem and the role that group characteristics play informing trust. With relatively small, stable groups of homogeneous users, trust and cooperation are possible so that joint investment may emerge as an equilibrium. This solution for "governing the commons" has been well-documented (Ostrom 1990, 2011; Ostrom and Gardner, 1993; Janssen and Anderies, 2011; York and Schoon, 2011). Unfortunately, these were not the conditions facing most migrants to the West, who were part of a large-scale immigration originating from a variety of geographic and cultural backgrounds.

We argue that prior appropriation was uniquely suited to solve the credible commitment problem in a setting where the informal basis for trust was absent. The particular problem is to constrain players in the second period to use the quantity of water dictated by the contract and supply sufficient investment in the first period. The quantification of appropriative water rights accomplished this by assigning the right to annually divert a pre-specified amount of water from a particular location with a beneficial use requirement that stipulated the water be diverted as claimed or lost to the next priority claimant. Within that fixed diversion amount, a sharing rule could be devised. Once diversion rights were quantified, contracts of the form $\left\{\left[\frac{\delta^{2}}{4 \delta^{2}-1}, 1-\right.\right.$ $\left.\left.\frac{\delta^{2}}{4 \delta^{2}-1}\right], \delta^{2}, \delta^{2}\right\}$ would be enforceable in court because property rights to specific quantities of water had been assigned.

\footnotetext{
17 This is a classic prisoner's dilemma where both players would be better off if cooperation could be mutually enforced, but both have a dominant strategy to play non-cooperatively.
} 
Under perfect enforcement or sufficiently costly punishment, player 1 would no longer defect from the contract in second period so that all contracts satisfying $\left\{\left[\frac{\delta^{2}}{4 \delta^{2}-1}, 1-\right.\right.$ $\left.\left.\frac{\delta^{2}}{4 \delta^{2}-1}\right], \delta^{2}, \delta^{2}\right\}$ are incentive compatible for both players-cooperation can emerge. Under any other water right system that did not explicitly quantify diversion and subsequent ditch user water claims, $\left\{\left[\frac{\delta^{2}}{4 \delta^{2}-1}, 1-\frac{\delta^{2}}{4 \delta^{2}-1}\right], \delta^{2}, \delta^{2}\right\}$ would not be supportable as an equilibrium because opportunism in the second period would preclude incentives to invest in the first period. Fixing rights to a specific amount based on initial appropriation solved the credible commitment problem and made coordinated investment a possible outcome of an otherwise dismal coordination game.

Analysis of $\delta$ shows that priority-based allocation of prior appropriation made successful investment more likely in two ways. First, more secure rights make the gains from coordination larger by increasing expected water deliveries for a given amount of investment. Second, higher values of $\delta$ increase the range of possible sharing rules that satisfy the incentive compatibility constraints for both players. This creates more flexibility in possible contractual outcomes, making coordination less likely to fail. Prior appropriation guarantees that claims made in a given period are secure against future entry, essentially fixing $\delta=1$ for early claimants by honoring water deliveries in the order in which rights were established. Agreement and cooperation become less likely as $\delta$ falls and rights become less secure. ${ }^{18}$ This suggests that prior appropriation may have been expecially effective at facilitating cooperation among early claimants with high priority along a given stream.

Table 1 provides a summary of the potential outcomes of the game under different institutional assumptions. Each row of the table corresponds to a different institutional setting: the first row depicts outcomes when no contract is attempted, the second row depicts the outcome of a game with an unenforceable contract, and the final row depicts the outcome under prior appropriation, where contracts are enforced. The columns show outcomes of key variables consistent with rational play by both players under each institutional setting - the realized sharing rule, investment levels, expected water deliveries, and associated profit. Note that investment and expected profits are increasing in the security of claims $\delta$ for feasible values of $\theta$ under prior appropriation.

Next, we consider the more general case of $N$ players along a ditch to briefly analyze the effect of group size on incentives to cooperate. The model generalizes in a straightforward way to the case of $N$ players. The welfare maximizing set of investments is given by $x_{i}^{*}=\delta^{2}$, which results in expected total water $\delta W-1=\delta[2 N \delta]-1=2 N \delta^{2}-1$. And the incentivecompatible set of shares for each individual, denoted $\theta_{i}$, must satisfy:

$$
\begin{gathered}
\sum_{i=1}^{N} \theta_{i}=1 \\
\theta_{i}(2 N-1) \delta^{2}-1 \geq 0 \Leftrightarrow \theta_{i} \geq \frac{1}{(2 N-1) \delta^{2}} \quad \forall i
\end{gathered}
$$

\footnotetext{
${ }^{18}$ In fact, if $\delta<.5$, the contracts we discuss are no longer feasible because both players' incentive compatibility constraints cannot be simultaneously met. Intuitively, if the probability of water delivery is too low, the expected surplus from coordination is too small to entice cooperation.
} 
if we again assume that some players have access to the water before others during the second period, we get the same result as in the 2-player version: without a rule to quantify and restrict water use, cooperation cannot be supported as an equilibrium.

In the case of $N$ players it is possible to study how the payoffs to a given individual change as the group grows larger, for a given sharing rule $\theta_{i}$. Suppose that users agree to share water equally so that $\theta_{i}=\frac{1}{N} \forall i .{ }^{19}$ Then, with a contract specifying efficient contributions, the payoff to individual $i$ as a function of $N$ is $U_{i}(N)=\frac{1}{N}(2 N-1) \delta^{2}-1$. Differentiating with respect to $N$ we see that $\frac{\partial U_{i}(N)}{\partial=N}=\frac{\delta^{2}}{N^{2}}>0$. The upshot is that if individuals can agree to an equal sharing rule with full investment participation, individual profits are strictly increasing in group size (though at a decreasing rate). ${ }^{20}$ Whereas informal coordination becomes less likely as groups grow large due to bargaining problems (Ostrom, 1990). Accordingly, well-specified property rights provide a basis for robust collective action in large groups in the asence of other coordinating institutions.

The extensions to our model underscore how priority allocation reshaped the economic problem facing irrigators in the West. Absent a secure quantified water right with a priority guarantee, the arrival of additional claimants on a stream would reduce access for incumbent users-captured in our model by a decrease in $\delta$. Under a regime where $\delta$ declines and $N$ grows, users are less likely to coordinate with one another and would undertake actions to deter additional entry on a given stream. Under prior appropriation $\delta$ remains fixed even as additional users arrive so that incumbent claims are secure and the arrival of new claimants actually increases the opportunity for Pareto-improving contractual arrangements, a condition not found with a riparian system. Granting more secure property rights via quantification and priority created the potential for cooperation via contracts for investment and trade where before there existed only zero-sum competition and rent dissipation.

While Ostrom (2011) points to several examples of community-based provision of irrigation works through institutions such as the Mormon Church, the large number of heterogeneous migrants arriving over a broad time horizon precluded an Ostrom (1990)-style solution to these collective action problems across most of the West. Instead, contractual arrangements formed the primary basis for cooperation because they allowed individuals to claim a defined diversion amount of water based on priority. With a defined diversion amount the parties could either combine assets and assign responsibilities and penalties for water delivery and ditch maintenance or create legal entities which could pursue financing from creditors in the eastern United States or elsewhere and offer water to subscribers.

\subsection{Testable Implications}

Our model yields several testable predictions about the behavior of individuals under prior appropriation which can be used to assess the validity of our argument that prior

\footnotetext{
${ }^{19}$ This sharing rule satisfies the incentive compatibility constraints so long as $\delta \geq \frac{1}{N}$

${ }^{20}$ Extending the game to $N$ players does introduce the possibility of smaller groups of size $n<N$ forming and building competing structures. It is possible contracts designed by these smaller groups could dominate some contracts associated with a group of size $N$ for some of the players. That is, a group of size $N$ may not be coalition proof. We do not explore these issues here except to note that the sole investment, non-cooperative outcome would still be dominated by these coalitions and so the qualitative finding that prior appropriation facilitated group formation is robust to this possibility.
} 
appropriation solved an economically-important contracting problem. These predictions center on two important aspects of the decision to establish a water right: where to establish a claim along a stream and whether to formally coordinate investment decisions with other claimants.

The decision by junior claimants of where to establish a water right provides a test of whether cooperation with other claimants was actually a key feature of the economic problem of irrigation. In the baseline scenario with no cooperative interaction, Burness and Quirk (1980) show that under prior appropriation, junior claimants are unambiguously worse off than are senior claimants along a given stream because there is less water available for claiming and whatever claim they establish will have less security during drought. In our setting, the ability to cooperate and pool capital with other users could overwhelm this effect, however. Our model predicts that the benefits of cooperation are increasing in $N$ under certain sharing rules, which would suggest benefits from locating diversion claims near other claimants.

The literature on first possession in patent contexts also indicates that first possession serves as a reward for early investment in settings where such investments generate a positive externality (e.g. research and innovation). In our setting, it is possible that innovation in how and where to divert water lowered claiming costs for subsequent claimants given general uncertainty about the environment and facilitated cooperation among adjacent parties.

The ability to cooperate around quantified water rights and the potential for private investments and water rights trading to generate positive social value constitute the primary benefits associated with prior appropriation and with first possession more broadly. It is possible that prior appropriation emerged as dominant due to these benefits. On the other hand, prior appropriation may have been selected by early claimants in order to protect rents associated with being first-movers. The former explanation would predict that junior users would prefer to locate near existing claims in order to benefit from positive spillovers and to potentially engage in joint investment, whereas the latter would imply that early users captured rents so that subsequent claimants would locate elsewhere. Therefore, we examine the choice of where to establish a water right and predict, consistent with our theory, that new users will be more likely to establish claims near previous claimants.

In addition to directly testing for whether new claimants follow prior claimants, we derive predictions about the effect of different resource characteristics on the decision of where to establish a water right. The importance of collective action and potential social value associated with investment in irrigation works both derive from our characterization of the underlying challenges facing claimants in the West. We emphasize the uncertainty associated with irrigation investment where there is a new climate and there are high fixed costs associated with the rugged terrain and the distance between irrigable lands and available water. If uncertainty and resource scarcity were significant factors, we would expect claiming behavior to be more responsive to resource characteristics that are easier to observe. Factors that affect the value of diverted water and can be observed directly - topography, current flow, and elevationare predicted to have a larger effect on claims than resource characteristics that are costlier for users to deduce such as flow variability over time and soil quality. Users are also more likely to be responsive to first-order resource characteristics such as drought.

Analyzing the determinants of where users choose to establish their water rights can provide reduced-form evidence about the potential benefits of an appropriative system, but our theory hinges on benefits asscoaited with coordinated investment. Our second set of predictions relates directly to the outcomes of our model: cooperation and investment. Our model predicts that coordinated outcomes through contracting are more likely when prior claims are more 
secure against future entry because the menu of efficient, incentive-compatible contracts is larger. ${ }^{21}$ While the model demonstrates that this makes agreement most likely under prior appropriation vis a vis other possible property rights regimes, such as a riparian system that did not assign priority, it also has direct implications for the probability of cooperation within the appropriative system itself. Burness and Quirk (1980) show that higher priority users have a higher probability of receiving their water right in any given year because flows are stochastic and senior users must be satisfied before junior users. In the context of our model, this means that higher priority users have a higher value of $\delta$, which means the set of feasible contracts is larger for high priority users. Accordingly, we predict that higher priority users are more likely to cooperate and jointly invest because the gains of doing so are larger.

We test our claim that cooperative contracts built around appropriative rights facilitate investment by comparing ditch investment by cooperative vs. non-cooperative claimants. As our model demonstrates, contracting outcomes which specify both investment and fixed stream water sharing rules ex ante lead to greater levels of investment than when individuals claim water and invest in an uncoordinated manner. Moreover, cooperative claimants may be able to exploit economies of scale associated with overcoming the high fixed costs and internalizing network externalities. Thus, we predict that cooperative users will tend to establish larger diversion infrastructure.

\subsection{Formal vs. Informal Institutions: Division 1 vs. 3}

Our theorized explanation for the emergence of prior approrprition emphasizes the lack of alternative institutions for collective action across much of the West, and particular circumstances in Colorado allow us to test whether prior appropriation does in fact function as a substitute for other coordingating institutions. Differences in resource and user characteristics between geographic Water Divisions 1 (South Platte) and 3 (Rio Grande) in northeastern and southcentral Colorado as shown in Figure 3 provide a novel setting for analyzing the comparative advantages of formal property regimes, relative to informal institutions for collective action. Broadly, conditions in Division 3 were consistent with the necessary conditions for successful common-pool resource management laid out by Ostrom (1990), whereas conditions in Division 1 were not. Differences in geography between Divisions 1 and 3 meant that there was much greater potential for entry of subsequent claimants in Division 1; the average number of potential riparian homesteads across all streams was 50 in Division 1 but just 28 in Division 3. Similarly, Division 1 was much more heavily settled than Division 3, increasing potential bargaining costs for water users in the absence of property rights. The average township in Division 1 had 84 homestead claims, compared to 11 homesteads per township in Division 3.

Division 3, composed mainly of the San Luis River Valley, was one of the oldest settled regions in Colorado. Whereas Division 1 and the Colorado eastern plains were settled by more recent waves of eastern and European migrants, who formed formal mutual ditch companies to access capital and develop and maintain irrigation systems, Division 3 had a predominantly Hispanic population living in small, close-knit communities with relatively long use of communal norms to govern ditch investment and management as well as irrigation water allocation (Mead, 1901; Hutchins, 1928; Crawford, 1988; Smith, 2016). Community-owned

\footnotetext{
${ }^{21}$ Here we assume that a larger set of incentive-compatible contracts that maximize the social surplus make agreement more likely because there are more possible bargaining outcomes in this set. Various factors could influence what outcome is chosen in any given context, but a larger set should make agreement more likely.
} 
large ditches, or acequia madres, were managed by ditch bosses (mayordomos) who oversaw construction and annual maintenance contributions by local users, rotated water access, and arbitrated disputes. ${ }^{22}$ This setting required little outside capital investment and the collective action problem was solved by custom (Hutchins, 1928; Meyer, 1984, pp. 64-73, 81; Smith, 2016). As we pointed out above, Division 1 was comprised of larger numbers of heterogeneous migrants from elsewhere in the US (Hicks and Pena, 2003). In this setting, the legal doctrine of prior appropriation was the common denominator among parties seeking to form and finance an irrigation network (Hobbs, 1997, p. 4; Crisfasi, 2015).

This key difference between the two geographic jurisdictions allows us to assess the role of formal property rights as a coordinating mechanism with and without the presence of informal institutions. ${ }^{23}$ The conditions in Division 3 were consistent with settings in which social norms serve as a sufficient basis for limiting new entry on a stream and for building trust that "headenders" on a ditch will not behave opportunistically when choosing how much water to appropriate in the second stage of the irrigation game from our model. Indeed, the conditions outlined above are similar to the examples of successful informal cooperation outlined by Ostrom and Gardner (1993). In this setting, investment can and does occur even without formal property rights, therefore the added benefit of priority appropriation as a mechanism for enforcing contracts is small to non-existent. This is in direct contrast to Division 1, where there was no other feasible enforcement mechanism. An implication of the model is that appropriative rights will generate larger benefits across a variety of outcomes in Division 1 than in Division 3.

We summarize our hypotheses below before describing the data and our empirical tests:

1. An increase in the number of claims on a stream will increase the number of subsequent claims on that stream.

2. Easily observed resource characteristics such as topography and average flow will be stronger determinants of claiming locations than are less apparent characteristics such as flow variability and soil quality.

3. Fewer claims will be established during drought.

4. Users with higher priority are more likely to cooperate in investing in diversion infrastructure.

5. Cooperative claimants make larger investments than non-cooperative claimants.

6. Larger investments, indicated by ditch length, require more cooperating claimants.

7. Where there are norms to solve collective action problems regarding water access and use, formal prior appropriation will play less of a role in infrastructure investment.

\section{Empirical Evolution of Prior Appropriation Claims}

\subsection{Location Data}

We assemble a data set of all known original appropriative surface water claims in Colorado. We combine geographic information on the point of diversion associated with each right with data on hydrology, soil quality, elevation, homestead claims, and irrigation to test our

\footnotetext{
${ }^{22}$ In fact, observation of these and other acequias in northern New Mexico prompted the first settlers to attempt irrigation in eastern Colorado (Crisfasi, 2015).

${ }^{23}$ See Appendix Table B7 for a comparison of the two groups.
} 
hypothesis about the determinants of first-possession claims. ${ }^{24}$ As we note, Colorado is now divided into 7 Water Divisions that separately administer water rights, as depicted in Figure 3. We focus on Divisions 1 to 3 (the South Platte (1), Arkansas (2), and Rio Grande (3)), which compose the eastern half of Colorado, are home to the majority of the state's agriculture, and have more complete diversion data available than other divisions. For each claim we know i) the date and geographic location of original appropriation, ii) the name of the structure or ditch associated with the diversion, iii) the name of the water source, iv) the size of the diversion, and v) the use or type of right. We restrict our analysis to agricultural rights. ${ }^{25}$

Our goal is to characterize individuals' choices of where to establish first-possession claims to water over time, so we divide Divisions 1 to 3 into a grid of 1-square-mile sections and create measures of location quality by grid cell. ${ }^{26}$ Analyzing only the location where rights were actually claimed ignores a substantial amount of individuals' choice sets, so including information on other claimable locations is critical for avoiding selection bias.

Figure 6 shows a map of Divisions 1 to 3 with the original location of all claims in our data set, the major streams, and the grid squares used for the analysis. Areas with productive, loamy soil are shaded in green. ${ }^{27}$ The figure makes clear the massive spatial scale of the water resources in Colorado and the extent to which ignoring unclaimed locations discards valuable information about individuals' opportunity sets. We aggregate grid-level characteristics up to the stream level and construct a panel of 1,922 streams from 1852 (the date of the first claim in our data) to 2013 (the date of the most recent claim), resulting in 311,364 total observations of which we are able to constructing overlapping covariates for 248,745.

Table 2 provides variable names, definitions, and summary statistics for the stream-level data and Appendix A provides detailed descriptions of how the geographic covariates were constructed. Variables relating to the stock and flow of rights along a river change over time, whereas measures of resource quality are fixed. We aggregate from grid squares to streams for four reasons. First, priority varies by stream, so the fundamental trade-off between high-priority access and low information costs occurs at the stream level. Second, we observe variation in flow at the stream level, so subdividing beyond streams does not provide additional information about the water resource. Third, the count of claims in a given square mile in a given year is extremely small, by construction. Using such a fine spatial resolution reduces the variation in the dependent variable and results in an arbitrarily large number of zeros in the data. Fourth, the potential for measurement error in how we have delineated grid squares is reduced by aggregating to a larger spatial unit that is defined on the basis of underlying hydrologic variation rather than a more arbitrary partitioning of space.

\subsection{Identification}

\footnotetext{
${ }^{24}$ GIS data on water rights were obtained directly from the Colorado Department of Water Resources. To our knowledge this is the first time such a comprehensive dataset has been compiled for water rights in any western state.

${ }^{25}$ Most of the rights in our study area are agricultural; water rights associated with mining are primarily found in the western half of the state.

26 This grid approximates the Public Land Survey (PLSS) grid but fills in gaps where GIS data on PLSS sections are not available. Actual homesteads and other land claims were defined as subsets of PLSS sections, so grid-level variation is similar to actual variation in land ownership and land use.

${ }^{27}$ We use soil group B, which is composed primarily of loamy soil and is the most productive for agriculture.
} 
We test our first prediction by estimating the effect of previous claims on a given stream on the probability and expected count of subsequent claims on that stream. ${ }^{28}$ This gives our econometric model an inherently dynamic nature. We characterize the number of claims on stream $j$ in year $t$ using a Poisson distribution. ${ }^{29}$ The primary challenge to identification comes from the fact that there may location characteristics are observed to claimants but unobserved to us as researchers, so that the presence of prior claims could indicate unobserved characteristics making a site more desirable and cause us instead to attribute the effect of site quality to prior claims - the history of claims on a given stream could proxy for unobserved stream quality and bias our estimates upwards. We can condition on soil quality, roughness, population pressure, average stream flow, and stream variability, but any other variation in location quality observed by claimants but unobserved by us will bias our estimates if unaddressed.

Wooldridge (2005) provides a method for using initial values of $y_{j t}$ to estimate Average Partial Effects (APE) of $y_{j t-1}$ on $y_{j t}$ that are averaged across the distribution of unobserved heterogeneity. We assume that $y_{j t}$ has a Poisson distribution with conditional mean

$$
E\left(y_{j t} \mid y_{j t-1}, \ldots, y_{j 0}, \boldsymbol{x}_{\boldsymbol{j}}, u_{j}\right)=u_{j} \exp \left(x_{j t} \beta+y_{j t-1} \rho\right)
$$

where $u_{j}$ is a site-specific unobserved effect. Wooldridge shows that $\rho$ can be identified by specifying a distribution for $u_{j t} \mid y_{j 0} \boldsymbol{x}_{\boldsymbol{j}}$. In particular, if we assume

$$
u_{j}=v_{j} \exp \left(\delta y_{j 0}+\gamma \boldsymbol{x}_{\boldsymbol{j}}\right), \quad v_{j} \sim \operatorname{gamma}(\eta, \eta)
$$

then forming the likelihood function and integrating out the distribution of $u_{j}$ conditional on $y_{j 0}$ and $\boldsymbol{x}_{\boldsymbol{j}}$ results in an estimator that is equivalent to the random effects Poisson estimator in Hausman et al. (1984). We implement this solution and estimate a random effects Poisson model controlling for $y_{j 0}$ to recover the partial effects of the variables of interest, averaged over the distribution of $u_{j}$. Placing parametric restrictions on the distribution of unobserved heterogeneity and the conditional distribution of $\left(y_{j t} \mid y_{j t-1}, \ldots, y_{j 0}\right)$ allows us to use the initial values $y_{j 0}$ to trace the evolution of $y_{j t}$ separately from the unobserved effect. We prefer this method to a fixed effects approach, which would necessarily discard all streams that never receive a claim, resulting in potential selection bias. Our estimating equation is

NewClaims $_{j t}=u_{j} \exp \left(\rho\right.$ NewClaims $_{j t-1}+\beta_{1}$ AvgFlow $_{j}+\beta_{2}$ Roughness $_{j}+\beta_{3}$ Std. Dev. Flow F $_{j}+$ $\beta_{4}$ Drought $_{t}+\beta_{5}$ Homesteads $_{j t-1}+\beta_{6}$ WatershedAcres $_{j}+\beta_{7}$ TotalWaterClaimed $_{j t}+$ $\beta_{8}$ NewClaims $_{j t-1} \times$ AvgFlow $_{j}+\alpha$ NewClaims $\left._{j 0}\right)$.

Identification requires several assumptions. First, we must assume that we have correctly specified the densities for the outcome of interest and unobserved effects. We maintain this

\footnotetext{
${ }^{28}$ This is more appropriate than a multinomial approach because our hypotheses concern how changes in the characteristics of the possible choices themselves affect behavior, whereas multinomial choice models are designed to estimate how individual characteristics affect the choices that those individuals make. We lack data on individual characteristics but are able to construct rich panel data on locations, so we rely on dynamic panel methods for our estimations.

${ }^{29}$ In a given year most of the 1,922 streams receive zero new claims, there cannot be a negative number of claims, and the maximum number of claims on any stream in a given year is 62 .
} 
assumption, emphasizing the count nature of our dependent variable and the standard use of a gamma distribution for modeling random effects in similar contexts. ${ }^{30}$ Second, we must assume that $v_{j}$ is independent of $\boldsymbol{x}_{\boldsymbol{j}}$ and $y_{j 0}$. This requires that the random component of the unobserved heterogeneity in site quality be random and not dependent on observed covariates. ${ }^{31}$ Our covariates are either fixed geographic characteristics or lagged values of other variables, making this assumption plausible.

Third, we must assume that the dynamics of $y_{j t}$ follow a first-order Markov processthat the dependence of $y_{j t}$ on the complete history of claims in the same location can be summarized by the relationship between $y_{j t}$ and $y_{j t-1}$. We argue that conditioning on the cumulative diversions along a stream-an element of $\boldsymbol{x}_{\boldsymbol{j}}$-alleviates concern that the cumulative stock of claims prior to period $\$ \mathrm{t}-1 \$$ could directly affect $y_{j t}$. In any given period, users direct their location choice on the basis of what users in the previous period did and the total amount of the resource that is still available for claiming, but the total number of claims is not directly relevant except through its effect on $y_{j t-1}$. Claims from the previous period provide a signal to potential followers about whether claiming on stream $j$ is profitable, given the declining rents of claiming on a given stream as claims accumulate. Beyond this signal, the effect of prior claims will be captured in our measurement of cumulative prior diversions.

\subsection{Empirical Results: Claiming Decisions}

Table 3 reports the results of the random effects Poisson estimator. We calculate and report the estimated average marginal effects of each of the covariates on the probability of a stream receiving at least one new claim in a given year, evaluated at the means of other variables. ${ }^{32}$ All specifications control for stream size and variability (Summer Flow and Flow Variability), drought, land quantity and quality (Roughness, Acres Loamy Soil, Watershed Acres), population pressure (Lagged Homestead Claims), and Initial Claims (required for identification). Column 2 controls for the total amount of water already claimed on a stream, and Column 3 also controls for the total number of acres already homesteaded in the same township as the stream. We predict that claims will be more likely when water is abundant (higher Summer Flow, less water claimed, and Drought $=0$ ) and when there is population pressure (more lagged Homestead Claims). We also predict that limited information with high search costs implies that difficult-to-assess variables like Flow Variability and Soil Quality should not affect claiming behavior. We interact Lagged Claims with Summer Flow in all specifications to better understand the underlying tradeoff between water available and potential coordination benefits. The key test for the existence of benefits from coordination and positive externalities is whether the marginal effect of Lagged Claims is positive.

Nearly all of the variables in Table 3 have the expected signs. Across all three specifications, the probability of new water claims is greater when there are more Lagged Water Claims or Lagged Homestead Claims, Watershed Acres are greater, and the stream-measured by Summer Flow-is larger. New Claims are less likely during Drought and when more of the land around the stream has already been homesteaded. In Column 2, more Total Water Claimed

\footnotetext{
${ }^{30}$ We perform a variety of simulations and confirm that the estimator is robust to alternative data generating processes for $u_{j}$.

${ }^{31}$ But note that the unobserved component $-u_{j}$-is allowed to depend on $\boldsymbol{x}_{\boldsymbol{j}}$ and $y_{j 0}$.

${ }^{32}$ Averaged across the distribution of unobserved heterogeneity $u_{j}$.
} 
reduces the probability of new claims, but the coefficient becomes positive in Column 3 once we control for Total Homesteaded Acres, implying that the scarcity of the water and land endowments was linked.

The fact that claims were less prevalent during drought, combined with users' unresponsiveness to stream variability, points to the possibility of dissipation through overclaiming of the resource over time. Claims are more likely when water is more abundant, indicating a first-order responsiveness to resource abundance that does not account for the underlying variability in the resource. It so happens that much of the settlement of the Great Plains and the western United States occurred during a period of unusually high rainfall (Libecap and Hansen, 2002; Hansen and Libecap, 2004). This bias in the timing of water claims, rather than some inherent institutional weakness in the initial allocation of property rights, can explain the mismatch between legal water rights and available supplies observed today.

Consistent with our intuition, several of the variables have no effect of the probability of new water claims on a stream. Long-term Flow Variability and Acres of Loamy Soil are insignificant, with precisely estimated zero coefficients in all three specifications. This is consistent with our hypothesis that claimants in the 19th century faced significant information problems. Migrants were unable to assess the inter-annual variability of stream flow or the viability of soil because they lacked knowledge of the long-term climate, water supplies, and necessary farming techniques in the region, as was the case across the West.

A key prediction of the model is that an increase in the number of claimants on a stream will increase the number of subsequent claims on that stream. In fact, the results in Table 3 provide strong evidence for the existence of significant benefits from coordination and positive spillovers in the definition of prior appropriation water rights. The estimated coefficient on Lagged Claims is statistically significant across specifications and indicates that the probability of at least one new claim on a stream in any particular year increases by about a half of a percentage point for each claim established on that stream the previous year. This is an effect size of roughly $20 \%$, as the mean probability of new claims is just $2.5 \%$, meaning that the presence of just five new claims on a stream doubles the probability of new claims on the same stream in the following year.

We are able to rule out the possibility that claimants' decisions to locate near prior claimants are driven by other benefits not related to water claims by examining the role of population growth in the evolution of water rights. Although the existence of new homestead claims in the same township as a stream makes new claims on that stream more likely by about 0.02 percentage points in the following year, a single water claim has the same effect on the probability of new claims as roughly 22 homestead claims. This indicates that water claimants' decision to follow prior claimants was driven by benefits specific to the definition of water rights rather than by a general positive benefit of locating near other settlers on the frontier. ${ }^{33}$ In Section 5 we analyze the mechanisms for this resource-specific benefit, focusing on the benefits of cooperation with other water users.

\footnotetext{
33 Information benefits provided by early claimants included demonstration of where and how irrigation ditches could be constructed. The best locations to build dams and reservoirs in order to divert water from the stream into a ditch were not obvious initially and had to be discovered by experimenting. Ditch slope for gravity water flows was critical as was the curvature of ditch canals to avoid erosion and leaks (Stenzel and Cech, 2013, pp. 74-96).

Techniques for irrigating flat, plateaued lands above stream channels were particularly valuable, but not initially apparent. The development of these methods attracted waves of subsequent settlers to jointly claim water for ditch investment and land in areas previously considered unproductive (Boyd, 1890).
} 
The estimated effect of Lagged Claims is also large relative to other covariates. Claims are more likely to be established on larger streams, but the effect of a single lagged claim is equivalent to a $95 \mathrm{cfs}$ increase in Summer Flow, about 1/3 greater than the average stream's Summer Flow of 68 cfs. Similarly, although claims are about $40 \%$ less likely during a major drought, the presence of just two prior claims on a stream could offset this major resource shock. These relative magnitudes demonstrate the economic significance of the externalities generated by early claimants - the information and potential coordination benefits of locating near prior claimants are on par with major shifts in the availability of water resources.

The benefits of locating near prior claimants are on par with major changes in expected resource availability, but the accumulation of prior claims itself reduced resources available for future claimants. Column 2 of Table 3 indicates that an increase in the cumulative volume of claimed water on a stream reduces the probability of new claims on that stream by a statisticallysignificant but economically-small margin - an increase in the volume of claimed water of over $100,000 \mathrm{cfs}$ would be required to offset the positive effect of a lagged claim. In contrast, an increase in the cumulative total of homesteaded acres along a stream reduced the probability of new claims by about $1 \%$ for every 1,800 acres claimed (roughly ten homesteads).

Reductions in available resources had a real effect on claimants' behavior, although the effect of water availability is quite small. This minuscule effect may be driven by claimants' lack of full knowledge of the legal volume of prior claims - the sum of "paper" water rights may not have been of primary concern to settlers as they observed flows and chose claim sites. If claimants imperfectly understood or partially disregarded the actual measurement of water, then the average Summer Flow of a stream is likely to be a better measure of what they perceived the resource constraint to be.

To assess the trade-off between resource availability and coordination benefits, we estimate the effect of Lagged Claims on the probability of New Claims for different size streams and plot the results in Figure $7 .^{34}$ The vertical axis is the estimated marginal effect of Lagged Claims on the probability of at least one new claim on a stream, and the horizontal axis is average stream size. The figure shows how the effect of Lagged Claims on the probably of a new claim varies with stream size and depicts a clear trade-off between the benefits of following earlier users and the reduced expected benefits from decreased water availability. The positive effect of lagged claims is monotonically increasing in stream size. Claimants were more likely to follow prior users on larger streams than on smaller ones, indicating that the benefits of coordination are larger when more water is available for development. ${ }^{35}$

All told, we find strong evidence of high information costs and resource constraints that are mediated by benefits from coordination and positive spillovers in the search and investment required to establish and exercise prior appropriation water rights. Conditional on resource availability, homestead pressure, and unobserved site quality, an increase in the number of new water claims along a particular stream increases the probability of new claims along that same stream in the next year by $20 \% .{ }^{36}$ When deciding where to establish a claim, new users are more

\footnotetext{
${ }^{34} \mathrm{We}$ do this by including an interaction term between Lagged Claims and Summer Flow, which is present in all of the models whose marginal effects are presented in Table 3.

${ }^{35}$ It may also be that the range of learning opportunities was narrowed on smaller streams, where the number of possible diversion sites and techniques was smaller than on large streams.

${ }^{36}$ In a series of robustness checks, discussed in Appendix B, we find evidence of attenuation bias due to excess zeros and find that alternative estimators produce larger estimated marginal effects than our main results reported in Table 3, which should be interpreted as a lower bound on the magnitude of positive spillover effects from investment.
} 
responsive to choices of earlier claimants than they are too many important, but difficult-toobserve, resource characteristics. The fact that claims are more likely when water is abundant indicates a systematic bias in the timing of claims that explains the overcapacity of irrigation infrastructure described contemporarily by Teele (1904), Coman (1911), and Hutchins (1929).

\subsection{Robustness}

We re-estimate our model using a set of alternative estimators to evaluate the robustness of our identification strategy given the unique character of our data set. Three primary concerns could threaten identification. First, our data set contains a large number of 0 s because in any year most streams receive 0 claims. ${ }^{37}$ Second, the distribution of unobserved heterogeneity may be incorrectly specified if $v_{j}$ is not independent of $x_{j}$--we are relying on a functional form assumption for identification. Third, estimates of $\rho$ are biased if the errors in our model are serially correlated. More broadly, we rely on a distributional assumption for identification and wish to show that our estimates are robust to alternative assumptions.

We address the first two problems by reproducing the estimated marginal effects from Table 3 using a random effects Probit—also discussed in Wooldridge (2005)—where the dependent variable is a dummy that is equal to 1 if there was a new claim along stream $j$ in year $t$. The Probit is more robust to the presence of excess zeros because it is designed for only 0 and 1 outcomes, whereas the Poisson distribution is more sensitive. The results are reported in Appendix Table B1. To alleviate further concern over our identifying assumptions about the relationship between $v_{j}$ and $\boldsymbol{x}_{\boldsymbol{j}}$, we estimate fixed effects Poisson and fixed effects Logit models and find results similar to the random effects Poisson and Probit. These results are reported in Appendix Tables B2 and B3. ${ }^{38}$

We address the problem of potential serial correlation in the error in two ways. First, we restrict the data set to claims prior to 1950 and estimate the model by using a linear GLS technique from Hsiang (2010) that allows for an AR(1) structure in addition to spatial autocorrelation in the error term. Second, we perform a series of Monte Carlo simulations to understand the behavior of the random effects Poisson estimator in the presence of serially correlated errors and/or excess 0 s in the dependent variable. Our results suggest attenuation bias in the presence of either complication, suggesting that our estimates are lower bounds on actual effect sizes.

\section{Economic Implications of Prior Appropriation}

\subsection{Claim-Level Data}

Next, we analyze the economic outcomes associated with prior appropriation, focusing on coordination, investment, and trade. We use a single water right as the unit of analysis in this section and develop separate, rights-level measures of the geographic covariates from the previous section by matching rights to the characteristics of the grid sections within 10 miles of

\footnotetext{
${ }^{37}$ In any given year, most of the 1,922 streams in our sample do not receive new claims. Moreover, the identifying assumption for the random effects probit is slightly less restrictive for our setting in that it requires that the probability of a new claim in year $t$ depends only on whether there was a claim in the previous year and not whether there were claims in other, earlier years.

${ }^{38} \mathrm{We}$ do not estimate marginal effects in these models. Instead, we report the raw coefficient estimates.
} 
each right, providing measures of the quality of nearby lands that would have been available for development. We also construct the variable CoOp, which is equal to 1 for claims established on the same stream on the same day as other rights. We argue that these rights are associated with ditch companies and other forms of formal contractual cooperation (Hutchins, 1929). ${ }^{39} \mathrm{We}$ obtained GIS data on irrigation canals and ditches for Divisions 1 (South Platte) and 3 (Rio Grande) in addition to GIS data on crop choice and irrigated acreage by crop for certain historical years from the Colorado Department of Water Resources. ${ }^{40}$ Each right has a unique identifier number that we use to match to ditches and irrigated lands, resulting in 550 rights for which we have complete data, including the size of the ditch associated with each right in addition to the location and size of irrigated lands associated with the right, by crop. Table 4 provides summary statistics.

Stream flow, flow variability, and homesteads are defined by stream as in Section 4 . We measure the quality of the land endowment or potential land endowment associated with each right slightly differently in this section than in Section 4. For each right we calculate the number of acres of loamy soil within 10 miles of the point of diversion in addition to the roughness of the terrain within a 10-mile radius of the point of diversion. We also calculate the total acreage of all 1-mile grid squares that are adjacent to the stream. These variables capture the quality of the land endowment available for claiming in proximity to each right. For the subset of our data that we are able to match to actual irrigated areas, we calculate the characteristics of irrigated lands associated with each right. We control for these covariates because the quality of the land and water resources near each right may bias our estimates of the effect of property rights on returns to irrigation if unaddressed.

To measure farm size, we calculate the total number of acres irrigated associated with each right for which we have matching data, captured in the variable Irrigated Acres. Our irrigation data also tell us how many acres of which crops were irrigated with the water from each right. We match these to estimates of average yield per acre and prices for Colorado for each crop in our data set from the Census of Agriculture from 1936 and 1956 to estimate the total value of irrigated agricultural output for each water right. We multiple irrigated acreage from the water rights data by the average yield per acre for that crop for that year in Colorado and then use average prices from Colorado for the relevant year to estimate the value of output. The variable Total Income reports the crop income associated with a right in a given year, in 2015 dollars. These data form our primary basis for estimating the returns to irrigated agriculture in Colorado. ${ }^{41}$

Next, we document the role of formal property rights as a coordinating institution for resolving collective action problems associated with the development of natural resources with focus on prior appropriation and ditch investment. To do this, we estimate the effect of prioritydifferentiated water rights on coordination and investment in irrigation infrastructure in Colorado. First, we examine the determinants of cooperation across all of eastern Colorado, focusing on the hypothesis that users with more secure (higher-priority) water rights are more likely to coordinate, this corresponds to the prediction from our model that higher values of $\delta$

\footnotetext{
${ }^{39}$ The names of the ditches associated with each right can be used to consult the historical record as to whether they were formally incorporated. We have done this for a subset of the rights and find that our measure of cooperation is reasonable proxy for formal cooperation.

${ }^{40}$ We use data for 1956 for Division 1 and 1936 for Division 3. No data are available for Division 2.

${ }^{41}$ Because there are potentially other irrigated parcels for which the Department of Water Resources does not have data, our estimates of the value of agricultural production due to the expansion of irrigated acreage made possible by the prior appropriation doctrine may be biased downward.
} 
increase both the gains from coordination and the menu of possible welfare-maximizaing contracts. Then, we use a subset of our data to estimate the effect of coordination on investment and how this effect varies across different institutional settings. Here we provide the first detailed empirical evidence to support the discussion of irrigation as a collective action problem originated by Coman (1911) and maintained by Ostrom (2011) and Hanemann (2014). We do this using data on ditch investment and income per acre for Divisions 1 (South Platte) and 3 (Rio Grande), which comprised markedly different institutional settings for the development of prior appropriation.

\subsection{Property Rights Security and Coordination}

We examine the determinants of cooperation, focusing on the prediction of the model that users with more secure (higher-priority) water rights are more likely to coordinate in irrigation investment. Priority is an ordinal ranking of rights along a stream. Including this simple priority measure in a regression would force the effect of priority to be linear, implying that the difference between being the 1st and 2nd claimant is the same as the difference between being, say, the 14th and 15th claimant. To allow for a non-linear, semi-parametric effect of priority on cooperation in ditch construction, we rank rights by priority and create bins for each decile of the distribution of priority by stream, yielding 10 dummy variables-one for each decile. For example, if the 1st Decile Dummy is equal to 1, the associated water right was among the first $10 \%$ of claims along its stream and had high-priority access to water during drought. This approach allows changes in priority to affect the probability of coordination differently at different points in the distribution of priority.

The biggest threat to identification of the effect of priority on investment is that rights with higher priority also tend to be established earlier in time, when less water has been claimed and less development has taken place. It could be that cooperation is more advantageous under these conditions, in which case we would potentially conflate the effect of priority with the effect of timing. Our measure of priority is relative to the total number of claims within a given stream; the top $10 \%$ (for example) of claims involves a different number of users for each stream, so priority may not be highly correlated with the extent to which a given stream is already developed. To further address potential identification issues, we will estimate the effect of priority on investment within watershed, conditional on the total amount of land development along the stream, as we describe below.

We use a fixed-effect logit regression to obtain semi-parametric estimates of the marginal effect of priority on coordination among rights holders in infrastructure investment, relying primarily on within-watershed variation for identification. ${ }^{42}$ The dependent variable is a dummy that is equal to 1 for rights that are established on the same stream on the same day. We control for stream characteristics, land quality within ten miles, population pressure, and watershed and year fixed effects. Table 5 presents the estimated marginal effects of each priority decile on the probability of cooperation, relative to the 5th decile. ${ }^{43}$ Columns 1 and 2 are estimated jointly for all three divisions, whereas columns 3 and 4 report the results for Divisions 1 and 3 separately.

\footnotetext{
${ }^{42}$ We use watershed fixed effects rather than stream fixed effects because coordination and spatial competition over irrigation works was often not limited to a single stream. Rather, development occurred based on what lands where arable, which varies by watershed.

${ }^{43}$ Marginal effects are estimated at the median values of the controls, and standard errors are clustered by watershed.
} 
As hypothesized, we find a higher probability of coordinating for investment in infrastructure for rights above the 5th Decile and a lower probability of coordinating for rights below the 5th Decile. Figure 8 depicts the marginal effects of each priority decile on cooperation associated with the model in Column 2 of Table 5. Users with prior appropriation water rights in the top $10 \%$ of priority on a given stream are about 12 percentage points more likely to jointly establish claims and ditches than are users in the middle decile, while very junior right-holders in the 10th decile are 20-30 percentage points less likely to coordinate. Taken together, these estimates imply that water right-holders with the highest priority on a stream were 40 percentage points more likely to coordinate with one another than were the most junior rights holders. This general pattern holds within Division 1 and Division 3 separately, particularly with respect to the lowest-priority right-holders. As Figure 8 indicates, much of this effect is concentrated in the bottom half of the distribution of priority - the effect of priority on investment is larger for users with low priority.

Those rights holders with the most variable water supply were the least likely to jointly invest in irrigation capital. By contrast, rights holders in the top half of the priority distribution face relatively smaller differences in their exposure to water supply variability and have a high likelihood of securing water and not stranding ditch capital and hence have a similar probability of coordinating among their members. However, each drop in priority in the lower half of the distribution represents a larger shift in real access to water, generating larger effects on the probability of coordination. The more heterogeneous users become in their exposure to risk, the less likely they are to cooperate. This finding is consistent with that of Wiggins and Libecap (1985), who find that cooperation among oil field operators in oil field coordination and investment becomes less likely as they become more heterogeneous.

\subsection{Formal Rights for Coordination in Investment and Exchange}

We now assess the extent to which ditch investment differed according to whether or not claimants coordinated with other water rights holders: Cooperation among water claimants leads to greater irrigation infrastructure investment. Our measure of investment is the length of the ditch (in meters) associated with a given water right. Longer ditches were costlier to construct but allowed users access to more valuable farmland, particularly in Colorado, where land adjacent to streams was often rugged and unsuitable for farming Hayden (1869). The costs of ditch investment had to be borne up front, before there was reliable information about the availability of water over time.

Coordination between water rights holders could increase ditch investment because i) it allowed users to share these up-front costs, ii) it allowed for the possibility of pooling water claims during times of limited flow to maximize the value of irrigated agriculture, iii) it created a framework for governance and assignment of maintenance responsibilities, and iv) it helped prevent post-contractual opportunism from informal promises of water deliveries (Hanemann, 2014; Crifasi, 2015, p. 158). Users who cooperated still developed individual ditches known as laterals to bring water to their own particular fields. This gives us unique ditch lengths for each water right in this portion of our sample, even if those users were part of a cooperative effort.

Table 6 reports our estimates of the effect of cooperation and priority on Ditch Meters using a GMM approach developed by Hsiang (2010) that adjusts for possible spatial and timeseries autocorrelation in the error term. We include watershed and decade fixed effects and a 
variety of controls for access to water and land resources. ${ }^{44} \mathrm{We}$ estimate the model across Divisions 1 and 3, allowing us to directly test whether ditches tended to be longer in either division and whether cooperation had a differential effect in Division $1 .{ }^{45}$ Average ditch length is not statistically different between the two divisions, suggesting that underlying factors influencing the profitability of ditch investment were similar across divisions. The effect of cooperation on ditch investment differs markedly, however. We find that cooperative claimants' ditches are 13,609 to 15,436 meters ( 8.5 to 9.6 miles) longer than those of non-cooperative claimants' in Division 1 but that coordination does not affect ditch investment in Division 3.

Two possible alternative explanations for the null effect of coordination on investment in Division 3 are that the predominantly Hispanic population either i) lacked full access to the legal system for enforcing prior appropriation claims or ii) had less wealth and access to credit than settlers in Division 1, thereby reducing investment. The fact that high-priority claimants are more likely to cooperate in Division 3, just as in Division 1 (Table 5) makes it unlikely that legal status varied sharply between groups, pointing toward another explanation for differences in investment incentives. Another possibility is that difference in wealth led to different investment outcomes. However, differences in wealth would result in less ditch building overall but should not reduce the role of formal coordination for projects that were undertaken. Instead, we argue that the differential role of formal coordination in Divisions 1 and 3 can be explained by the dominant communal norms in Division 3, which rendered formal property institutions less crucial in that area. In contrast, Division 1 required formal legal rights as a basis for coordination among many heterogeneous claimants.

One potential concern with our results on ditch investment is that investment and cooperation are jointly determined, making CoOp endogenous in Table 6. If this is true, then the finding that $\mathrm{CoOp}$ ditches are longer may be due to simultaneity bias. We argue that the empirical time line associated with establishing and then developing a water claim resolves this issue. While intended ditch length may be simultaneously determined with whether or not a right is claimed cooperatively, actual ditch construction is a costly and time-consuming process-the average ditch in our sample is 10.5 kilometers $(6.5$ miles) long. The upshot is that the cooperative status of a water claim is exogenous to ditch length because the former necessarily predates the latter. A similar concern could be stated and similarly dismissed with respect to the endogeneity of priority.

To check the robustness of our results we reproduce them first by omitting priority and then by using the number of claims in the same month and same watershed as a given right as an instrument for $\mathrm{CoOp}$ and obtain similar estimates of key parameters. The number of claims in the same month and same watershed as a given right affects the probability of cooperation because rights established nearby other rights (in space and time) have more other claims with which to potentially cooperate. At the same time, the number of new claims in a given month should not directly affect the investment of any particular claim, except through its effect on the cooperative status of that claim. In general we find that after controlling for coordination, priority has no direct effect on ditch investment. For the sake of brevity we do not report the coefficients for each decile, but they are available in Appendix Table B5.

To illustrate the role of priority on investment in Division 1, consider the McGinn Ditch on South Boulder Creek and north Boulder Farmer's Ditch on Boulder Creek. Both ditches were large, cooperative investments. The McGinn Ditch was constructed in 1860 and had the number

${ }^{44}$ The pattern of spatial dependence follows Conley (2008).

${ }^{45}$ Ditch data are not available for Division 2. 
2 priority on South Boulder Creek. Farmer's Ditch was the longest ditch in the Boulder Valley when it was constructed in 1862, costing $\$ 6,500$ (\$165,000 in 2015 dollars) and irrigated over 3,000 acres of land (Crifasi, 2015, p. 187). Even larger ditches followed. The Larimer and Weld Canal from the Cache La Poudre River, was constructed sequentially between 1864 and 1878 with the huge capacity of $720 \mathrm{cfs}(5,400$ gallons) and was 53 miles long to irrigate 50,000 acres (Hemphill 1922, p. 15; Dunbar 1950, p. 244). Construction costs for such ditches were financed either through forming non-profit mutual ditch companies among irrigators or through organizing commercial ditch companies including a broader group of investors, such as the Colorado Mortgage and Investment Company of London, England (Dunbar 1950, pp. 253-58, Libecap 2011, p. 73). Such mutual ditch companies were the most common form of water supply organization in Division 1 and within them shareholders held a pro rata ownership in the water rights of the company and were subject to assessments for maintenance and development costs (Adams, 1910, pp. 37-42; Hutchins, 1929; Rettig, 2012, p. 3).

Earlier we argued that with designated water diversion rights under prior appropriation, safe from new riparian claimants, parties would have an incentive to announce their locations in order to encourage others to locate nearby. Indeed, the more costly the infrastructure investment, the more parties needed to pool funds in cooperative development. To test this notion, we analyze whether group size affects ditch length and whether this effect varies between Division 1 and 3 and report the results in Table 7. We use the same econometric setup used in the Table 6 except that we use group size instead of a dummy for whether individuals are in a group as the main explanatory variable. As before we control for priority, topography, homesteads, claim year, as well as watershed fixed effects. An interaction between the Division 1 dummy variable and our measure allows us to say how the effect of group size on ditch length is different across divisions - the coefficient on Group Size gives the effect in Division 3 and is zero. The coefficient on Division 1 x Group Size gives the difference in the effect between Divisions 1 and 3 or equivalently - since the effect in Division 3 is zero - the effect of group size on ditch length in Division 1. Depending on specification, the effect is between 2,000 and 3,000 meters (1.24 to 1.86 miles) for each additional group member. These results underscore the importance of attracting sufficient claimants to cooperatively invest in irrigation infrastructure, and prior appropriation provided the security of water diversion for that investment to take place.

Further supportive evidence for our statistical results is shown by the actions of migrants to the Cache La Poudre Valley in the 1870s. First, they relied upon scouting to ascertain the best ditch diversion and farmland locations. Second, they advertised for others with capital and settlement objectives to join them-something that would not have happened under a riparian system. For example, at least 59 were included in the over 1,000 who responded to advertisements in the New York Tribune for the Union Colony at Greeley. Third, they formally pooled resources to develop irrigation infrastructure that cost $\$ 412,000$ in 1873 or $\$ 8,229,233$ in 2015 dollars to irrigate some 12,000 acres (Boyd, 1890, pp. 12, 31-38, 55, 59). Other colonies or groups of potential irrigators found diversion sites and organized ditch companies throughout eastern Colorado (Stenzel and Cech, 2013, p. 101).

Definite water rights via formal prior appropriation also facilitated related cooperation through market exchange of water rights for optimal ditch size construction. Over time, some ditch locations became more favorable than others as new information emerged about additional productive agricultural lands to be tied to the irrigation network. Main canals required extension and widening to carry more water further and to support added feeder ditches. Such expansion was made possible through acquisition of other relatively senior (secure) water rights along a 
stream and consolidation of diversions within the expanded canal. Table 8 reports the clustering of water rights from various ditches through water rights trade to support some of the largest canals on the Cache La Poudre River in Colorado: the Laramer County Canal, Jackson Ditch, Larimer and Weld Canal, and Greeley Union Colony Canals 1 and 3, as reported by the USDA in 1922, 60 years after the earliest, highest priority water diversion claims. Notice that original ditch water claims were augmented by others of varying priority. In some cases multiple original claims were combined behind one ditch, whereas for others, particularly more junior, but favorably-located ditch claims, the rights of other more senior claimants were purchased to secure sufficient water. Such consolidation of water for infrastructure would not have been feasible under the default riparian system.

\subsection{Irrigation and Income Per Acre}

Ultimately the purpose of establishing a water right in Colorado was to provide water as an input to irrigated agriculture. Prior appropriation added value to agricultural endeavors by encouraging search and investment and by separating water rights from riparian land holdings, allowing for much greater and more productive areas to be irrigated than would have been possible under the riparian system. To estimate the magnitude these benefits, we begin by depicting the extent of land resources that could have been irrigated under the riparian doctrine, given that settlers on the Western frontier were generally constrained to homestead sites totaling 160 to 320 acres. We conservatively assume that land within a half mile of a stream or river could have been claimed and considered to be adjacent to the water for the purposes of assigning riparian water rights.

Figure 9 depicts riparian lands in eastern Colorado-indicated by cross hatch shadingand the location of loamy soils (hydrologic soil call B) best suited to farming-indicated with green shading - and reveals that the riparian doctrine would have both constrained the total area of land available for farming and have precluded the ability to irrigate some of the most productive soils in the region that were remote from streams. We match our data on water rights with GIS data on actual irrigated acreage prior to the advent of groundwater pumping in Divisions 1 and 3 to calculate the actual contribution of the prior appropriation doctrine to agriculture in the region.

Figure 10 depicts riparian land and actual irrigated acreage in 1956 for Division 1 and 1936 for Division 3, the earliest years for which GIS data are available in each division. ${ }^{46} \mathrm{We}$ focus on these early years so that we can isolate the effect of access to surface water as from the effect of access to groundwater. ${ }^{47}$ Roughly $45 \%$ of the irrigated land in Division 1 and $34 \%$ in

\footnotetext{
${ }^{46}$ Data for a contemporaneous cross-sectional or panel comparison are not available. To alleviate concern about the comparison over time, we collect county-level data on the number of farms, average farm size, and average farm value for both areas in 1935 and 1954 (the closest years to our sample years for which data are available) from the Census of Agriculture. We calculate the percentage change in each outcome between 1935 and 1954 and find no statistically significant difference in changes over time across divisions. The total number of farms fell in both divisions, while both average farm size and value increased. We also collect data on average yields for irrigated wheat in both periods in both divisions and find no statistically significant difference in the change in yield from 1936 to 1956 across divisions. These tests imply that economic conditions in agriculture in the two divisions moved in similar ways over the 20-year period.

${ }^{47}$ Estimates from later in the 20th century are contaminated by the ability of farmers to supplement their surface water rights by pumping groundwater. The technology for groundwater pumping became widely available after World War II.
} 
Division 3 were riparian. The ability to claim water from streams and put it to use on nonadjacent land allowed for substantial growth in irrigated acreage in both divisions, resulting in an additional 546,552 acres of usable farmland - an increase of $133 \% .^{48}$

Focusing on income per acre allows us to better understand the contribution of prior appropriation to farm productivity. We combine our rights-level data on irrigated acres and crop choice with historical state-level data from the Census of Agricultural on prices and yields for each crop to estimate the value of production on riparian and non-riparian lands. These results are summarized in Table 9. The value of non-riparian irrigated agricultural production was $\$ 228,480,781$ in Division 1 and $\$ 58,583,937$ in Division 3. The ability to move water away from streams increased combined agricultural output in Colorado in our sample years by $134 \%$.

The variation in income per acre across land type and division is striking. In Division 1, the average non-riparian farm earned roughly $\$ 20$ more per acre than the average riparian farm, while farms in Division 3 exhibit no difference. ${ }^{49}$ This suggests that non-riparian lands were more productive than riparian lands. This is consistent with the fact that users incurred substantial infrastructure costs to reach non-riparian lands and left much of the riparian corridor untouched.

The information in Table 9 makes it clear that the riparian system would have constrained rights holders to the more rugged terrain adjacent to streams and limited total farm size, assuming only riparian homesteads had access to water. This, in turn, would have precluded important 20th-century innovations in farming technology centered around the development of large, flat farms in the West (Gardner, 2009; Olmstead and Rhode, 2001). Previous studies of prior appropriation have emphasized the ability to separate water from streams as a necessary condition for irrigation in the arid West, but this does not explain fully why a first-possession mechanism was adopted. Another necessary ingredient for successful irrigation was an incentive structure to facilitate costly investment. The results described in Tables 5 and 6 suggest that first possession provided this incentive structure by granting a more secure property right and those in Table 9 confirm that non-riparian lands were in fact more productive and allowed for larger farms.

Taken together, these results suggest that formal coordination under the prior appropriation doctrine was an important determinant of per-acre income for farmers. Coordination facilitated ditch investment, which in turn provided access to more productive land and may have allowed for more efficient, larger farms and cooperation along other productive margins. The equation below summarizes the possible channels through which building a cooperative ditch could increase per-acre income.

$$
\frac{d I P A}{d \operatorname{CoOp}}=\frac{\partial I P A}{\partial A \text { Ares }}\left[\frac{\partial \text { Acres }}{\partial \text { Ditches }} \times \frac{\partial \text { Ditches }}{\partial \operatorname{CoOp}}+\frac{\partial \text { Acres }}{\partial \operatorname{CoO} p}\right]+\frac{\partial I P A}{\partial \text { Ditches }} \times \frac{\partial \text { Ditches }}{\partial \operatorname{CoOp}}+\frac{\partial I P A}{\partial \operatorname{CoO} p}
$$

We estimate a series of linear regressions using the GMM technique mentioned above to obtain each of the partial derivatives and to construct the total effect of coordination on income per acre. Table 10 presents our estimates of the effect of cooperation on income per acre by

\footnotetext{
48 These land-based estimates form an upper bound on the expansion of irrigated agriculture made possible by prior appropriation. The counterfactual scenario involving adherence to the riparian doctrine may have resulted in more riparian land being irrigated, given that non-riparian lands would have been unavailable.

${ }^{49}$ This difference is statistically significant at the $99 \%$ level. Newell $(1894$, p. 6) provides estimates for the value of irrigated agricultural production/acre at \$361/acre for all of Colorado (in $2015 \$$ ).
} 
division. The results used to construct these estimates are available in Appendix Table B6. The first row of Table 10 reports the reduced-form estimate of cooperation on income per acre, not controlling for ditch length or farm size. The second row contains our estimate corresponding to the various channels, estimated using GMM with spatial HAC standard errors that are uncorrelated across equations, and the third row presents a robustness check using seemingly unrelated regression (SUR) to account for possible correlation in the errors across equations.

Income per acre was $\$ 105$ to $\$ 132$ higher (relative to a mean of $\$ 544$ per acre) for users in Division 1 who coordinated their water rights claims and investment. This exceeds the average difference in productivity for non-riparian vs. riparian farms reported in Table 9 by a factor of five. While reaching non-riparian lands did lead to greater income per acre, users who cooperated generated even greater benefits. This suggests that ditch investment was critical for productivity and that the ability to build longer ditches via formal cooperative arrangements (documented in Table 6) increased productivity substantially by granting access to the most productive lands.

In contrast, we find no effect of cooperation on income per acre in Division 3. This difference is driven largely by the fact that coordination promoted ditch investment in Division 1 but not in Division 3. Both divisions faced a classic collective action problem in the development of irrigation works. In Division 3 this problem was largely solved in a classic Ostrom (1990) manner with cultural norms and informal mechanisms, which worked well given the small number of homogeneous users. In this settings formal property rights added little value. Division 1 was rapidly settled by a large number of heterogeneous claimants, making a norm-based solutions untenable. Here, the collective action problem was solved by contracting based on formal, legal property rights.

\subsection{Irrigated Agriculture and the Development of the West}

By the late 19th century the role of irrigated agriculture in expanding economies was increasingly recognized (Newell, 1894). We perform a back-of-the-envelope calculation of the contribution of irrigated agriculture and prior appropriation to economic development in the Western United States in the early 20th century. Table 11 presents our estimates of the value of irrigated crop production for western states in 1910 and 1930. We use data from Easterlin (1960) and from the Bureau of Economic Analysis on personal income by state and the 1910 and 1930 US Censuses of Agriculture to estimate the value of irrigated crops and report those estimates as a percentage of state or territory income. ${ }^{50}$ Finally, using an average of the share of non-riparian

\footnotetext{
${ }^{50}$ Department of Commerce, BEA Survey of Current Business, May 2002 and unpublished data, "Personal Income and Personal Income by State, 1929-2001," provided to the authors by Robert A. Margo. State income values were calculated on a state basis by multiplying population by per capita income. Population data for 1910 and 1930 from US Agricultural Data, 1840-2010, distributed by the Inter-University Consortium for Political and Social Research (ICPSR). For 1910, per capita income was calculated by taking the mean of per capita income from 1900 and 1920. Per capita income from 1900 was taken from Easterlin 1960, Table A-3. Per capita income for 1920 and 1930 were taken from unpublished data from Easterlin and the BEA. The 1910 values of irrigated crops were calculated by summing individual crop values by state. Data from irrigated crop values were taken from the 1910 Census of Agriculture, Volumes 6 and 7. The 1910 Census of Agriculture notes that data for irrigated crops were taken from supplemental schedules, and the information is considered to be incomplete. Therefore, all available irrigated crop value data were summed. The 1930 values of irrigated crops were calculated by summing the eight most valuable crops according to state. The number of crops included in the calculation was chosen to be eight, as the 9th crop value added less than 5\\% to the total irrigated crop value. Data for irrigated crop values were taken from US Agricultural Data, 1930, distributed by ICPSR.
} 
income in total agricultural income from Divisions 1 and 3 in Colorado, we estimate the value of non-riparian irrigated agriculture as a percentage of state income. ${ }^{51}$ This represents the estimated share of state income due to agricultural production that could not have taken place under the riparian doctrine.

The data in Table 11 indicate that irrigation of non-riparian lands contributed $2 \%$ to $14 \%$ of state income in 1910 and $3 \%$ to $21 \%$ in 1930 . Moreover, we estimate that more than half of the value generated by irrigated agriculture came from non-riparian lands. This estimate may be an upper bound on the value-added by prior appropriation because strict adherence to the riparian doctrine would likely have led to the irrigation of more riparian lands, relative to what we observe today. On the other hand, Adelman and Robinson's (1986) estimation of general equilibrium multipliers from increases in the value of agricultural production suggest that the contribution of irrigated agriculture to state incomes reported here due to access to more productive non-riparian lands may be considerably understated. Still, our back-of-the-envelope calculation gives a sense of the importance of infrastructure investment for the development of irrigated agriculture in the West. Western states relied on irrigation for a substantial portion of their income by 1930, and our analysis has shown that the structure of water rights under prior appropriation was uniquely suited to overcome the investment and coordination issues facing claimants on the unknown Western Frontier.

\section{Conclusion}

Prior appropriation created an institutional framework for cooperation to generate socially-valuable investments that lowered information costs regarding the most favorable diversion locations. Prior claims raised the probability of subsequent claims by $20 \%$, an effect equivalent to a near doubling of stream size in attracting settlers. The ability to coordinate and combine formal, tradable prior appropriation rights along with greater certainty of water deliveries for high-priority rights holders facilitated joint development of canal systems. The top $10 \%$ of senior claimants were 40 percentage points more likely to form ditch companies than were those below the median priority. This cooperation in turn led to a doubling of average ditch length (about $10 \mathrm{~km}$, or 6.2 miles) that greatly expanded irrigable, high-quality land, especially in Division 1. Longer ditches brought more productive non-riparian land under irrigation, with the longest, cooperative ditches adding over $\$ 100$ per acre to productivity.

Prior appropriation water rights not only encouraged investment relative to a riparian system, but were exchanged routinely to consolidate and redirect water-something not possible with riprian rights (Hemphill, 1922). There was no detectable effect, however, in Division 3 where formal rights appear not to have been required to coordinate effort. Overall, under prior appropriation between $3.5 \%$ and $20 \%$ of western state incomes by 1930 were directly attributable to irrigated agriculture, much of which would not have been feasible under the default riparian rights system. These estimates do not incorporate multiplier effects from higher agricultural incomes that might have doubled the economic impact in each state.

The value of any particular form of property right to a natural resource depends on its ability to align individual incentives to reconcile competing demands and to encourage

\footnotetext{
${ }^{51}$ We calculate a weighted average of the share of non-riparian income of total irrigated income from Divisions 1 and 3, weighted by total irrigated acreage in each division. We estimate that roughly $57 \%$ of irrigated land is nonriparian and could not have been irrigated under a strict riparian system.
} 
innovation, cooperation, investment, and reallocation. The western frontier provides a unique laboratory for analyzing the development or modification of property institutions. Prior appropriation emerged in response to new conditions in a setting where institutional change could occur at relatively low cost with high expected net returns. The migration of thousands of frontier claimants was fueled by anticipation of capturing resource rents that required a new property rights regime. Although migrants were numerous and dissimilar in many ways, they carried with them common notions of individual ownership of land and other natural resources and an ability to modify institutions as local conditions suggested.

In the case of prior appropriation of water, claimants applied existing first-possession allocation of agricultural and mineral land to water, rather than adhering to an eastern riparian system that offered lower returns under semi-arid conditions. From historical persecptive, this appears to have been a low-cost solution to a collective action problem in a setting where neither govenmernt provision or informal, norm-based cooperation were feasible. The emergence and later legal adoption of de facto first possession claims to water created a basis for private investment in infrastructure on a staggering scale across the West.

This physical infrstracture and the institutions governing it still direct the allocation of water today. While the appropriative doctrine emerged on a relatively blank slate during westward expansion, policymakers today are constrained by the particular historical realities set in motion by that development itself. Recent policy discussions calling for a restructuring of water rights to shares of total annual allowable uses or to mandate instream environmental flows do not sufficiently consider the value of and stakes in the contemporary priority rights system. Unlike the earlier frontier setting, major uncompensated movement to any new institutional arrangement would not be at low cost.

Once in place, prior appropriation molded expectations for the creation and distribution of rents and the associated range of uses, exchange, time frames, and investment in water. These conditions remain today among property rights holders. In the face of new demands for water for environmental, urban, and industrial use along with more variable and possibly declining supplies, water rights will be exchanged and water reallocated (Brewer et al., 2008; Murphy et al., 2009; Culp et al., 2014). Western North America with its designated prior appropriation water rights system is unusual among semi-arid regions of the world, where rights often are neither defined precisely nor separable from the stream. This rights structure potentially provides for greater flexibility and incentive for reallocation and management for a most vital water resource. 


\section{References}

Acemoglu, D., S. Johnson, and J. Robinson (2001). The Colonial Origins of Comparative Development: An Empirical Investigation. American Economic Review 91(5), 13691401.

Acemoglu, D., S. Johnson, and J. Robinson (2005). The Rise of Europe: Atlantic trade, Institutional Change, and Economic Growth. American Economic Review 95(3), 546-579.

Adams, F. et al. (1910). Delivery of Water to Irrigators. Bulletin (United States. Office of Experiment Stations); no. 229 Washington D.C.: Government Accounting Office.

Adelman, I. and S. Robinson. (1986). U.S. Agriculture in a General Equilibrium Framework: Analysis with a Social Accounting Matrix. American Journal of Agricultural Economics, 68 (5), 1196-1207.

Anderies, J.M. and M.A. Janssen. (2011). The Fragility of Robust Social-Ecological Systems.Global Environmental Change 21(4): 1153-1156.

Anderson, T. L. and P. J. Hill (1975). The Evolution of Property rights: A Study of the American West. Journal of Law and Economics 18(1), 163-179.

Barzel, Y. (1968). Optimal Timing of Innovations. Review of Economics and Statistics 50(3), 348-355.

- (1994). The Capture of Wealth by Monopolists and the Protection of Property Rights. International Review of Law and Economics 14(4), 393-409.

— (1997). Economic Analysis of Property Rights. New York: Cambridge University Press.

Besley, T. J. (1995). Property Rights and Investment Incentives: Theory and Evidence from Ghana. Journal of Political Economy 103(5), 903-937.

Besley, T. J. and M. Ghatak (2009). Property Rights and Economic Development, Volume 5. New York: Elsevier Publishing.

Bohn, H. and R. T. Deacon (2000). Ownership Risk, Investment, and the Use of Natural Resources. American Economic Review 90(3), 526-549.

Boyd, D. (1890). A History: Greeley and the Union Colony of Colorado. Greeley, CO: Greeley Tribune Press.

Brewer, J., R. Glennon, A. Ker, and G. Libecap (2008). Water Markets in the West: Prices, Trading, and Contractual Forms. Economic Inquiry 46(2), 91-112. 
Burness, S. and J. Quirk (1979). Appropriative Water Rights and the Efficient Allocation of Resources. American Economic Review 69(1), 25-37.

- (1980a). Economic Aspects of Appropriative Water Rights. Journal of Environmental Economics and Management 7(4), 372-388.

- (1980b). Water Law, Water Transfers, and Economic Efficiency: The Colorado River. Journal of Law and Economics 23(1), 111-134.

Casey, K. E., C. M. Dewees, B. R. Turris, and J. E. Wilen (1995). The Effects of Individual Vessel Quotas in the British Columbia Halibut Fishery. Marine Resource Economics 10 (3), 211-230.

Cheung, S. N. (1970). The Structure of a Contract and the Theory of a Non-Exclusive Resource. Journal of Law and Economics 13(1), 49-70.

Chong, H. and D. Sunding (2006). Water Markets and Trading. Annual Review of Environmental and Resource Economics 31, 239-264.

Coman, K. (1911). Some Unsettled Problems of Irrigation. American Economic Review 1(1), $1-19$.

Conley, T. (2008). Spatial Econometrics. New Palgrave Dictionary of Economics, 741-7.

Costello, C., S. D. Gaines, and J. Lynham (2008). Can Catch Shares Prevent Fisheries Collapse? Science 321(5896), 1678-1681.

Crawford, S.G. (1988). Mayordomo: Chronicle of an Acequia in Northern New Mexico. Albuquerque: University of New Mexico Press.

Crifasi, R. R. (2015). A Land Made From Water. Boulder, Colorado: University Press of Colorado.

Culp, P. W., R. Glennon, and G. Libecap (2014). How the Market Can Mitigate Water Shortages in the American West. Washington D.C.: Island Press.

Dasgupta, P., R. Gilbert, and J. Stiglitz (1983). Strategic Considerations in Invention and Innovation: The Case of Natural Resources. Econometrica 51(5), 1439-1448.

Demsetz, Harold. (1967). Toward a Theory of Property Rights. American Economic Review 57(2), 347-359.

Dippel, Christian, Trevor O'Grady, C. Snider, and A. Whalley (2015). The American Frontier 1820-1940: Theory and Evidence from 5 Million Settler Choices. Working Paper.

Dixit, A. (2009). Governance Institutions and Economic Activity. American Economic 
Review 99(1), 3-24.

Dunbar, R. G. (1950). The Origins of the Colorado System of Water-right Control. The Colorado Magazine 27(4), 241-262.

— (1983). Forging New Rights in Western Waters. Lincoln, Nebraska: University of Nebraska Press.

- (1985). The Adaptability of Water Law to the Aridity of the West. Journal of the West 24(1), 57-65.

Easterlin, R. (1960). Interregional Differences in Per Capita Income, Population, and Total Income, 1840-1950. In Trends in the American Economy in the Nineteenth Century, pp. 73-140. Princeton, New York: Princeton University Press.

Edwards, J. and S. Ogilvie (2012). What Lessons for Economic Development Can We Draw from the Champagne Fairs? Explorations in Economic History 49(2), 131-148.

Ellickson, R. C. (1993). Property in Land. Yale Law Journal 102(6), 1315-1400.

Epstein, R. A. (1978). Possession as the Root of Title. Georgia Law Review 13, 1221-1243.

Galiani, S. and E. Schargrodsky (2010). Property Rights for the Poor: Effects of Land Titling. Journal of Public Economics 94(9), 700-729.

Gardner, B. L. (2009). American Agriculture in the Twentieth Century: How it Flourished and What it Cost. Cambridge, MA: Harvard University Press.

Gates, P. (1968). History of Public Land Law Development. Washington D.C.: Public Land Law Review Commission.

Gaudet, G., M. Moreaux, and S. W. Salant (2001). Intertemporal Depletion of Resource Sites by Spatially Distributed Users. American Economic Review 91(4), 1149-1159.

Getches, D. H. (2009). Water Law in a Nutshell. Eagan, MN: Thomson/West.

Gibson, C. and K. Jung. (2006). Historical Statistics of the Foreign-Born Population of the United States, 1850-2000, US Census Bureau Working Paper 81. Washington D.C.

Gordon, H. S. (1954). The Economic Theory of a Common-Property Resource: The Fishery. The Journal of Political Economy 62(2), 124-142.

Grafton, R. Q., D. Squires, and K. J. Fox (2000). Private Property and Economic Efficiency: A Study of a Common-Pool Resource. Journal of Law and Economics 43(2), 679-714.

Green, J. R. and S. Scotchmer (1995). On the Division of Profit in Sequential Innovation. The RAND Journal of Economics 26(1), 20-33. 
Greif, A., P. Milgrom, and B. R. Weingast (1994). Coordination, Commitment, and Enforcement: The Case of the Merchant Guild. Journal of Political Economy 102(4), $745-776$.

Hanemann, M. (2014). Property Rights and Sustainable Irrigation: A Developed World Perspective. Agricultural Water Management 145, 5-22.

Hansen, Z. K. and G. D. Libecap (2004a). Small Farms, Externalities, and the Dust Bowl of the 1930s. Journal of Political Economy 112(3), 665-694.

(2004b). The Allocation of Property Rights to Land: U.S. Land Policy and Farm Failure in the Northern Great Plains. Explorations in Economic History 41(2), 103-129.

Harris, C. and J. Vickers (1987). Racing with Uncertainty. The Review of Economic Studies 54 (1), 1-21.

Hausman, J., B. H. Hall, Z. Griliches, et al. (1984). Econometric Models for Count Data with an Application to the Patents-R\&D Relationship. Econometrica 52(4), 909-938.

Hayden, F. (1869). Preliminary Field Report of the United States Geological Survey of Colorado and New Mexico: US Geological Survey of the Territories, Third Annual Report. Washington D.C.: Government Printing Office.

Hemphill, R. G. (1922). Irrigation in Northern Colorado, USDA Bulletin Number 1026. Washington D.C.: US Government Printing Office.

Henz, J., S. Turner, W. Badini, and J. Kenny (2004). Historical Perspectives on Colorado Drought. Denver: Colorado Drought and Water Supply Assessment, Chapter 1. Colorado Department of Natural Resources.

Hess, R. H. (1916). The Colorado Water Right. Columbia Law Review 16(8), 649-664.

Hicks, G. A. and D. G. Pena (2003). Community Acequias in Colorado's Rio Culebra Watershed: A Customary Commons in the Domain of Prior Appropriation. University of Colorado Law Review 74(2), 387-486.

Hobbs, G. J. (1997). Colorado Water Law: An Historical Overview. University of Denver Water Law Review 1, 1-4.

Howe, C. W. (2005). Property Rights, Water Rights and the Changing Scene in Western Water. In C. Gopalakrishnan, C. Tortajada, and A. K. Biswas (Eds.), Water Institutions: Policies, Performance and Prospects, pp. 175-185. New York: Springer.

Hsiang, S. M. (2010). Temperatures and Cyclones Strongly Associated with Economic Production in the Caribbean and Central America. Proceedings of the National Academy of Sciences 107(35), 15367-15372. 
Hutchins, W. A. (1928). The Community Acequia: Its Origin and Development. Southwestern Historical Quarterly 31(3), 261-284.

- (1929). Mutual Irrigation Companies, USDA Technical Bulletin 82.

Washington D.C.: Government Printing Office.

- (1930). Commercial Irrigation Companies, USDA Technical Bulletin 177. Washington D.C.: Government Printing Office.

- (1931). Irrigation Districts, Their Organization, Operation, and Financing. USDA Technical Bulletin 254. Washington D.C.: Government Printing Office.

- (1977). Water Rights Laws in the Nineteen Western States, Volume 3. Natural Resource Economics Division, Economic Research Service, United States Department of Agriculture.

Jacoby, H. G., G. Li, and S. Rozelle (2002). Hazards of Expropriation: Tenure Insecurity and Investment in Rural China. American Economic Review 92(5), 1420-1447.

Johnson, R. N., M. Gisser, and M. Werner (1981). The Definition of a Surface Water Right and Transferability. Journal of Law and Economics 24(2), 273-288.

Kanazawa, M. T. (1996). Possession is Nine Points of the Law: The Political Economy of Early Public Land Disposal. Explorations in Economic History 33(2), 227-249.

— (2015). Golden Rules. Chicago: University of Chicago Press.

Leonard, B. and G. D. Libecap (2015). Endogenous First-Possession Property Rights in OpenAccess Resources. Iowa Law Review 100, 2457-2507.

Libecap, G. D. (2007). The Assignment of Property Rights on the Western Frontier: Lessons for Contemporary Environmental and Resource Policy. Journal of Economic History 67(02), 257-291.

- (2011). Institutional Path Dependence in Climate Adaptation: Coman's "Some Unsettled Problems of Irrigation." American Economic Review 101(1), 64-80.

Libecap, G. D. and Z. K. Hansen (2002). "Rain Follows the Plow" and Dryfarming Doctrine: The Climate Information Problem and Homestead Failure in the Upper Great Plains, 1890-1925. Journal of Economic History 62(01), 86-120.

Libecap, G. D. and R. N. Johnson (1979). Property Rights, Nineteenth-Century Federal Timber Policy, and the Conservation Movement. Journal of Economic History 39(1), 129-142.

Libecap, G. D., D. Lueck, and T. O'Grady (2011). Large-Scale Institutional Changes: Land 
Demarcation in the British Empire. Journal of Law and Economics 54(4), 295-327.

Lin, C., P. Lin, and F. Song (2010). Property Rights Protection and Corporate R\&D:

Evidence from China. Journal of Development Economics 93(1), 49-62.

Lueck, D. (1995). The Rule of First Possession and the Design of the Law. Journal of Law and Economics 38(2), 393-436.

- (1998). First Possession. In P. Newman (Ed.), The New Palgrave Dictionary ofEconomics and the Law, Volume 2, pp. 132-144. New York: Macmillan.

MacIntyre, D. D. (1994). The Prior Appropriation Doctrine in Montana: Rooted in Mid Nineteenth Century Goals—Responding to Twenty-First Century Needs. Montana Law Review 55, 303.

Mead, E. (1901). Irrigation in the United States. USDA Bulletin 105, Office of Experiment Stations. Washington D.C.: Government Printing Office.

Mehlum, H., K. Moene, and R. Torvik (2006). Institutions and the Resource Curse. Economic Journal 116(508), 1-20.

Meyer, M. (1984). Water in the Hispanic Southwest: A Social and Legal History, 1550-1850. Tucson: University of Arizona Press.

Murphy, J. J., A. Dinar, R. E. Howitt, S. J. Rassenti, V. L. Smith, and M. Weinberg (2009). The Design of Water Markets When Instream Flows Have Value. Journal of Environmental Management 90 (2), 1089-1096.

Newell, F. H. (1894). Report on Agriculture by Irrigation in the Western Part of the United States, at the Eleventh Census: 1890. Washington D.C.: US Government Printing Office.

Olmstead, A. L. and P. W. Rhode (2001). Reshaping the Landscape: The Impact and Diffusion of the Tractor in American Agriculture, 1910-1960. The Journal of Economic History 61(03), 663-698.

Ostrom, E. (1990). Governing the Commons: The Evolution of Institutions for Collective Action. Cambridge University Press.

-2011). Reflections on "Some Unsettled Problems of Irrigation." American Economic Review $101(01), 49-63$.

Ostrom, E. and R. Gardner (1993). Coping with Asymmetries in the Commons: Self-Governing Irrigation Systems Can Work. Journal of Economic Perspectives. 7 (4): 93-112.

Ostrom, V. (1953). State Administration of Natural Resources in the West. American Political Science Review 47(02), 478-493. 
Ostrom, V. and E. Ostrom (1972). Legal and Political Conditions of Water Resource Development. Land Economics 48(1), 1-14.

Pisani, D. J. (1992). To Reclaim a Divided West: Water, Law, and Public Policy, 1848-1902. Albuquerque: University of New Mexico Press.

- (2002). Water and American Government: The Reclamation Bureau, National Water Policy, and the West, 1902-1935. Berkeley: University of California Press.

Powell, J.W. (1879). Report on the Lands of the Arid Region of the United States. Second Edition. Washington D.C: Government Printing Office.

Rettig, P. J. (2012). Tracing the Source of Irrigation: An Examination of Colorado Ditch Company Collections in Archival Repositories. Journal of Western Archives 3(1): 1-20.

Rodrik, D. (2008). Second-Best Institutions. American Economic Review 98(2), 100-104.

Romero, T. I. (2002). Uncertain Waters and Contested Lands: Excavating the Layers of Colorado's Legal Past. University of Colorado Law Review 73, 521-1401.

Rose, C. M. (1985). Possession as the Origin of Property. University of Chicago Law Review 52 (1), 73-88.

- (1990). Energy and Efficiency in the Realignment of Common-law Water Rights. Journal of Legal Studies 19(2), 261-296.

Schorr, D. (2005). Appropriation as Agrarianism: Distributive Justice in the Creation of Property Rights. Ecology Law Quarterly 32(1), 3-71.

Scott, A. (1955). The Fishery: The Objectives of Sole Ownership. Journal of Political Economy, 116-124.

— (2008). The Evolution of Resource Property Rights. New York: Oxford University Press.

Smith, H. E. (2000). Semi-common Property Rights and Scattering in the Open Fields. Journal of Legal Studies 29(1), 131-169.

Smith, S. M. (2016). Common Property Resources and New Entrants: Uncovering the Bias and Effects of New Users. Journal of the Association of Environmental and Resource Economists 3 (1), 1-36.

Stenzel, R. L. and T. Cech. (2013). Water: Colorado's Real Gold: A History of the Development of Colorado's Water, and the Prior Appropriation Doctrine, and the Division of Water Resources. Denver: Richard Stenzel.

Teele, R. (1904). The Organization of Irrigation Companies. Journal of Political Economy 12 
(2), 161-178.

US Census Bureau. (1913). Thirteenth Census of the United States Taken in the Year 1910, Vol. V, Agriculture. Pt. 1, Chapter XI. Washington DC: Government Printing Office.

- (1922). Fourteeenth Census of the United States Taken in the Year 1920, Vol. VII, Irrigation and Drainage. Washington D.C.: Government Printing Office.

Wiggins, S. N. and G. D. Libecap (1985). Oil Field Unitization: Contractual Failure in the Presence of Imperfect Information. American Economic Review 75(3), 368-385.

Wilen, J. E. (2005). Property Rights and the Texture of Rents in Fisheries. In D. Leal (Ed.), Evolving Property Rights in Marine Fisheries, pp. 49\{67. Lanham, MD: Rowman and Littlefield.

Williamson, O. E. (1993). Opportunism and its Critics. Managerial and Decision Economics, 14 (2), 97-101.

Wooldridge, J. M. (2005). Simple Solutions to the Initial Conditions Problem in Dynamic, Nonlinear Panel Data Models with Unobserved Heterogeneity. Journal of Applied Econometrics 20(1), 39-54.

Worster, D. (2001). A River Running West: The Life of John Westley Powell. New York: Oxford University Press.

York, A. and M.L. Schoon. (2011). Collective Action on the Western Range: Coping with External and Internal Threats. International Journal of the Commons. 5 (2), 388-409. 
Table 1: Outcomes of the Irrigation Game

\begin{tabular}{|c|c|c|c|c||}
\hline & $\theta$ & $x_{1}^{*}, x_{2}^{*}$ & $E(W)-1$ & $\pi_{1}, \pi_{2}$ \\
\hline \hline No Contract & Undefined & $\delta^{2}, \delta^{2}$ & $\begin{array}{c}2 \delta^{2}-1, \\
2 \delta^{2}-1\end{array}$ & $\begin{array}{c}\delta^{2}-1 \leq 0, \\
\delta^{2}-\delta \leq 0\end{array}$ \\
\hline Contract-No Enforcement & 1 & $\delta^{2}, 0$ & $\begin{array}{c}2 \delta^{2}-1, \\
0\end{array}$ & $\begin{array}{c}\delta^{2}-1 \leq 0, \\
0\end{array}$ \\
\hline $\begin{array}{c}\text { Contract_Prior } \\
\text { Appropriation }\end{array}$ & {$\left[\frac{\delta^{2}}{4 \delta^{2}-1}, 1-\frac{\delta^{2}}{4 \delta^{2}-1}\right]$} & $\delta^{2}, \delta^{2}$ & $3 \delta^{2}-1$ & $\begin{array}{c}\theta\left(4 \delta^{2}-1\right)-\delta^{2}, \\
(1-\theta)\left(4 \delta^{2}-1\right)-\delta^{2},\end{array}$ \\
\hline
\end{tabular}


Table 2: Stream-Level Summary Statistics

\begin{tabular}{|c|c|c|c|c|c|c|}
\hline Variable & $\mathrm{N}$ & Mean & S.D. & Min & Max & Definition \\
\hline New Claims & 311,364 & 0.0253 & 0.529 & 0 & 61 & Number of new claims on stream $j$ in year $t$. \\
\hline NewClaim & 311,364 & 0.0110 & 0.1045 & 0 & 1 & Dummy variable equal to 1 if New Claims $>0$ in year $t$. \\
\hline Initial Claims & 311,364 & 0.00156 & 0.0510 & 0 & 2 & Number of new claims on stream $j$ in year 0 . \\
\hline InitialClaim & 311,364 & 0.00104 & 0.0322 & 0 & 1 & Dummy variable equal to 1 if Initial Claims $>0$. \\
\hline Summer Flow & 250,452 & 68.19 & 227.6 & 0 & 4,638 & Flow (cfs) on stream $j$ from May to August, averaged over $1890-2000$. \\
\hline Roughness & 311,202 & 290.1 & 282.5 & 0.174 & 3,299 & S. D. of slope multiplied by average slope along stream $j$. \\
\hline Flow Variability & 250,452 & 5.761 & 56.22 & 0.00687 & 1,353 & S. D. of summer ow from 1890 to 2000 . \\
\hline Drought & 311,364 & 0.160 & 0.367 & 0 & 1 & Dummy variable $=1$ during major drought years. \\
\hline Homestead Acres t-1 $_{1}$ & 309,281 & 77.66 & 677.5 & 0 & 72,628 & Number of acres homesteaded in township crossed by stream $j$ in year $t-1$. \\
\hline Homestead Claimst-1 & 309,281 & 0.399 & 2.837 & 0 & 242 & Number of homestead claims in township crossed by stream $j$ in year $t-1$. \\
\hline $\begin{array}{l}\text { Total Homesteaded } \\
\text { Acres }\end{array}$ & 311,364 & 7,905 & 20,085 & 0 & 326,297 & Cumulative acres homesteaded in township crossed by stream $j$ as of year $t$. \\
\hline Percent Claimed & 307,476 & 2.13 & 5.54 & 0 & 35.99 & Cumulative prior water claimed/Summer Flow on stream $j$ in year $t$. \\
\hline Watershed Acres & 311,364 & $5,460.68$ & $187,325.2$ & 18.43 & $8,215,323$ & Total size of watershed containing stream $j$ \\
\hline Acres Loamy Soil & 311,364 & 367.29 & $3,973.91$ & 0 & $173,086.5$ & Acres within 10 miles of stream $j$ with loamy soil. \\
\hline
\end{tabular}

Notes: 1) Data on homesteads were provided by Dippel et al. (2015) and are based on Bureau of Land Management digitization of all land patents from the settlement of the western United States. 2) Drought variables are based on major drought years described in Henz et al. (2004). 3) Annual historical ow estimates used to calculate ow variability could be constructed only for a subset of data due to the availability of other variables used in the hydrologic model. 
Table 3: Empirical Determinants of Prior Appropriation Claims

\begin{tabular}{|c|c|c|c|}
\hline \multirow{2}{*}{$\frac{\partial \operatorname{Pr}(\text { NewClaims }>0)}{\partial x}$} & (1) & (2) & (3) \\
\hline & \multicolumn{3}{|c|}{ Poisson Estimates, $Y=$ New Claims $_{j t}$} \\
\hline Lagged Claims & $\begin{array}{l}0.00556^{* * *} \\
(0.000658)\end{array}$ & $\begin{array}{l}0.00570^{* * * *} \\
(0.000621)\end{array}$ & $\begin{array}{l}0.00490^{* * *} \\
(0.000622)\end{array}$ \\
\hline Summer Flow & $\begin{array}{c}0.0000590^{*} \\
(0.0000330)\end{array}$ & $\begin{array}{l}0.0000594^{*} \\
(0.0000333)\end{array}$ & $\begin{array}{l}0.0000641^{*} \\
(0.0000345)\end{array}$ \\
\hline Flow Variability & $\begin{array}{l}-0.0000167 \\
(0.0000122)\end{array}$ & $\begin{array}{l}-0.0000172 \\
(0.0000125)\end{array}$ & $\begin{array}{l}-0.0000198 \\
(0.0000127)\end{array}$ \\
\hline Drought & $\begin{array}{l}-0.0105^{* * *} \\
(0.00158)\end{array}$ & $\begin{array}{l}-0.0101^{* * *} \\
(0.00169)\end{array}$ & $\begin{array}{c}-0.00832^{* * *} \\
(0.00132)\end{array}$ \\
\hline Roughness & $\begin{array}{l}-0.0000169 \\
(0.0000168)\end{array}$ & $\begin{array}{l}-0.0000170 \\
(0.0000169)\end{array}$ & $\begin{array}{l}-0.0000233 \\
(0.0000191)\end{array}$ \\
\hline Acres Loamy Soil & $\begin{array}{l}-0.00000191 \\
(0.00000313)\end{array}$ & $\begin{array}{l}-0.00000159 \\
(0.00000302)\end{array}$ & $\begin{array}{c}0.00000182 \\
(0.00000299)\end{array}$ \\
\hline Watershed Acres & $\begin{array}{l}0.00000500^{*} \\
(0.00000282)\end{array}$ & $\begin{array}{l}0.00000501^{*} \\
(0.00000289)\end{array}$ & $\begin{array}{c}0.00000520^{*} \\
(0.00000293)\end{array}$ \\
\hline Homestead Claims $t-1$ & $\begin{array}{l}0.000220^{* * * *} \\
(0.0000451)\end{array}$ & $\begin{array}{l}0.000254^{* * * *} \\
(0.0000550)\end{array}$ & $\begin{array}{l}0.000297^{* *} \\
(0.000133)\end{array}$ \\
\hline Initial Claims & $\begin{array}{l}0.00941^{* *} \\
(0.00394)\end{array}$ & $\begin{array}{l}0.00934^{* *} \\
(0.00386)\end{array}$ & $\begin{array}{c}0.00329 \\
(0.00505)\end{array}$ \\
\hline $\begin{array}{l}\text { Total Water Claimed } \\
\text { (cfs) }\end{array}$ & & $\begin{array}{l}-4.84 \mathrm{e}-08^{* *} \\
(2.33 \mathrm{e}-08)\end{array}$ & $\begin{array}{c}0.000000104^{* *} \\
\quad(5.20 \mathrm{e}-08)\end{array}$ \\
\hline $\begin{array}{l}\text { Total Homesteaded } \\
\text { Acres }\end{array}$ & & & $\begin{array}{l}-0.000000546^{* *} \\
(0.000000230)\end{array}$ \\
\hline $\mathrm{N}$ & 248,745 & 248,745 & 248,745 \\
\hline
\end{tabular}

Notes: Standard errors are clustered by stream and are reported in parentheses. $\mathrm{N}=248,745$ is the number of stream-year cells for which we have overlapping data on all covariates. ${ }^{*} \mathrm{p}<: 1$,

$* * \mathrm{p}<: 05, * * * \mathrm{p}<: 01$ 
Table 4: Claim-Level Summary Statistics

\begin{tabular}{|c|c|c|c|c|c|}
\hline $\mathrm{N}$ & Mean & S.D. & Min & Max & Definition \\
\hline 7,999 & 15.63 & 123.4 & 0 & 8,631 & Volume of water (cfs). \\
\hline 7,999 & $-23,211$ & 11,900 & $-39,346$ & 19,395 & Days since 1/1/1960. \\
\hline 778 & 605,953 & $2,833,755$ & 0 & $4.56 \mathrm{e}+07$ & Income from acres irrigated using right $i$ in year $t$. \\
\hline 778 & $1,592.6$ & $5,811.7$ & 1.516 & 91,987 & Total acres irrigated using right $i$ in year $t$. \\
\hline 778 & 544.44 & 390.91 & 68.23 & 1,933 & Income per acre from acres irrigated using right $i$ in year $t$. \\
\hline 778 & 10,658 & 28,420 & 45.06 & 352,729 & Meters of ditch associated with right $i$. \\
\hline 778 & 1.022 & 4.803 & 0 & 1 & Share of Irrigated Acres possessing loamy soil. \\
\hline 778 & 37.43 & 102.3 & 0 & 640 & Acres of loamy soil on acres irrigated by right $i$. \\
\hline 6,482 & 3,804 & 4,078 & 0 & 16,291 & Acres of loamy soil within 10 miles of right $i$. \\
\hline 7,889 & 5.258 & 4.291 & 0.0550 & 36.23 & Length of stream $(\mathrm{km})$ that right $i$ lies on. \\
\hline 7,999 & 0.259 & 0.438 & 0 & 1 & Dummy var. $=1$ for rights associated with cooperation or mutual ditches \\
\hline 778 & 1.017 & 2.169 & 0 & 11 & Size of group associated with claim ( $=0$ for noncooperative claims) \\
\hline 7,889 & 501.8 & 1,266 & 0 & 8,470 & Flow (cfs) on stream $j$ from May to August, averaged over 1890-2000. \\
\hline 6,337 & 23.82 & 145.6 & 0 & 1,224 & S. D. of summer ow from 1890 to 2000. \\
\hline 6,479 & 142.7 & 107.7 & 0.0720 & 934.2 & Avg. Slope times S. D. of Slope (within 10 miles of right). \\
\hline 6,482 & 11,022 & 11,902 & 0 & 53,696 & Total acres near stream $j$ associated with right $i$. \\
\hline 7,999 & 1896 & 32.54 & 1852 & 2013 & Year in which right $i$ was established. \\
\hline 7,999 & 346.3 & 1,297 & 0 & 35,463 & Acres homesteaded during year in which right $i$ was established. \\
\hline 7,999 & 2.179 & 7.024 & 0 & 131 & Number of new homesteads during year in which right $i$ was established. \\
\hline 7,999 & 0.248 & 0.432 & 0 & 1 & Dummy var. $=1$ claims with priority in top $10 \%$ on a stream. \\
\hline 7,999 & 0.0815 & 0.274 & 0 & 1 & Dummy var. $=1$ claims with priority in $11-20 \%$ on a stream. \\
\hline 7,999 & 0.0911 & 0.288 & 0 & 1 & Dummy var. $=1$ claims with priority in $21-30 \%$ on a stream. \\
\hline 7,999 & 0.0913 & 0.288 & 0 & 1 & Dummy var. $=1$ claims with priority in $31-40 \%$ on a stream. \\
\hline 7,999 & 0.0729 & 0.260 & 0 & 1 & Dummy var. $=1$ claims with priority in $41-50 \%$ on a stream. \\
\hline 7,999 & 0.111 & 0.314 & 0 & 1 & Dummy var. $=1$ claims with priority in $51-60 \%$ on a stream. \\
\hline 7,999 & 0.0973 & 0.296 & 0 & 1 & Dummy var. $=1$ claims with priority in $61-70 \%$ on a stream. \\
\hline 7,999 & 0.0783 & 0.269 & 0 & 1 & Dummy var. $=1$ claims with priority in $71-80 \%$ on a stream. \\
\hline 7,999 & 0.0780 & 0.268 & 0 & 1 & Dummy var. $=1$ claims with priority in $81-90 \%$ on a stream. \\
\hline 7,999 & 0.0499 & 0.218 & 0 & 1 & Dummy var. $=1$ claims with priority in $91-99 \%$ on a stream. \\
\hline
\end{tabular}


Table 5: Marginal Effects of Priority on Cooperation

\begin{tabular}{|c|c|c|c|c|}
\hline$Y=C o O p$ & \multicolumn{2}{|c|}{ Divisions 1-3 } & Division1 & Division3 \\
\hline $1^{\text {st }}$ Priority Decile & $\begin{array}{l}0.123^{* * *} \\
(0.0359)\end{array}$ & $\begin{array}{l}0.119^{* * *} \\
(0.0390)\end{array}$ & $\begin{array}{c}0.0207 \\
(0.0779)\end{array}$ & $\begin{array}{c}0.194^{* *} \\
(0.0797)\end{array}$ \\
\hline $2^{\text {nd }}$ Priority Decile & $\begin{array}{c}0.0541 \\
(0.0456)\end{array}$ & $\begin{array}{c}0.0725 \\
(0.0472)\end{array}$ & $\begin{array}{c}0.0154 \\
(0.0929)\end{array}$ & $\begin{array}{c}0.123 \\
(0.0999)\end{array}$ \\
\hline $3^{\text {rd }}$ Priority Decile & $\begin{array}{c}0.0882^{*} \\
(0.0468)\end{array}$ & $\begin{array}{c}0.119^{* *} \\
(0.0488)\end{array}$ & $\begin{array}{r}-0.00675 \\
(0.0861)\end{array}$ & $\begin{array}{c}0.202^{*} \\
(0.115)\end{array}$ \\
\hline $4^{\text {th }}$ Priority Decile & $\begin{array}{c}0.0318 \\
(0.0432)\end{array}$ & $\begin{array}{c}0.0419 \\
(0.0431)\end{array}$ & $\begin{array}{c}0.0624 \\
(0.0855)\end{array}$ & $\begin{array}{l}0.00619 \\
(0.0905)\end{array}$ \\
\hline $6^{\text {th }}$ Priority Decile & $\begin{array}{c}-0.0154 \\
(0.0518)\end{array}$ & $\begin{array}{r}-0.00285 \\
(0.0495)\end{array}$ & $\begin{array}{l}-0.0558 \\
(0.0698)\end{array}$ & $\begin{array}{c}0.0391 \\
(0.0995)\end{array}$ \\
\hline $7^{\text {th }}$ Priority Decile & $\begin{array}{c}0.0366 \\
(0.0401)\end{array}$ & $\begin{array}{c}0.0359 \\
(0.0421)\end{array}$ & $\begin{array}{l}-0.0761 \\
(0.0674)\end{array}$ & $\begin{array}{c}0.146 \\
(0.104)\end{array}$ \\
\hline $8^{\text {th }}$ Priority Decile & $\begin{array}{l}-0.0591 \\
(0.0447)\end{array}$ & $\begin{array}{l}-0.0910^{*} \\
(0.0485)\end{array}$ & $\begin{array}{l}-0.181^{* *} \\
(0.0753)\end{array}$ & $\begin{array}{l}-0.0301 \\
(0.0900)\end{array}$ \\
\hline $9^{\text {th }}$ Priority Decile & $\begin{array}{l}-0.160^{* * *} \\
(0.0465)\end{array}$ & $\begin{array}{l}-0.211^{* * *} \\
(0.0522)\end{array}$ & $\begin{array}{l}-0.238^{* *} \\
(0.0939)\end{array}$ & $\begin{array}{l}-0.292^{*} \\
(0.168)\end{array}$ \\
\hline $99^{\text {th }}$ Priority Percentile & $\begin{array}{l}-0.236^{\text {*** }} \\
(0.0643)\end{array}$ & $\begin{array}{l}-0.330^{* * *} \\
(0.0774)\end{array}$ & $\begin{array}{c}-0.488^{* * *} \\
(0.189)\end{array}$ & $\begin{array}{c}-5.193^{* * *} \\
(0.984)\end{array}$ \\
\hline $\begin{array}{l}\text { Homesteads } \\
\text { Summer Flow } \\
\text { Flow Variability } \\
\text { Roughness } \\
\text { Acres Loamy Soil }\end{array}$ & $\begin{array}{l}\text { Yes }^{* *} \\
\text { Yes }^{* * *} \\
\text { Yes } \\
\text { Yes } \\
\text { Yes }\end{array}$ & $\begin{array}{l}\text { Yes }^{*} \\
\text { Yes }^{* * *} \\
\text { Yes } \\
\text { Yes } \\
\text { Yes }\end{array}$ & $\begin{array}{l}\text { Yes } \\
\text { Yes* } \\
\text { Yes } \\
\text { Yes } \\
\text { Yes }\end{array}$ & $\begin{array}{l}\text { Yes } \\
\text { Yes }^{* *} \\
\text { Yes }^{*} \\
\text { Yes } \\
\text { Yes }\end{array}$ \\
\hline $\begin{array}{l}\text { Acres Along Stream } \\
\text { Watershed Fixed Effects } \\
\text { Year Fixed Effects }\end{array}$ & $\begin{array}{l}\text { Yes } \\
\text { No } \\
\text { Yes }\end{array}$ & $\begin{array}{l}\text { Yes } \\
\text { Yes } \\
\text { Yes }\end{array}$ & $\begin{array}{l}\text { Yes } \\
\text { Yes } \\
\text { Yes }\end{array}$ & $\begin{array}{l}\text { Yes } \\
\text { Yes } \\
\text { Yes }\end{array}$ \\
\hline$N$ & 4756 & 4354 & 1206 & 937 \\
\hline
\end{tabular}

Standard errors clustered by watershed and reported in parentheses

$$
{ }^{*} p<.1,{ }^{* *} p<.05,{ }^{* * *} p<.01
$$




\begin{tabular}{|c|c|c|c|c|}
\hline & (1) & $(2)$ & $(3)$ & (4) \\
\hline & \multicolumn{4}{|c|}{$Y=$ DitchMeters } \\
\hline Division 1 & $\begin{array}{c}2889.3 \\
(2368.4)\end{array}$ & $\begin{array}{c}5689.2 \\
(4827.0)\end{array}$ & $\begin{array}{c}2503.0 \\
(2994.1)\end{array}$ & $\begin{array}{c}6590.3 \\
(6089.9)\end{array}$ \\
\hline $\mathrm{CoOp}$ & $\begin{array}{c}-674.1 \\
(1573.0)\end{array}$ & $\begin{array}{c}-724.7 \\
(2195.5)\end{array}$ & $\begin{array}{l}-1022.6 \\
(1837.2)\end{array}$ & $\begin{array}{l}-1149.8 \\
(2117.7)\end{array}$ \\
\hline Division $1 \times \mathrm{CoOp}$ & $\begin{array}{c}15436.7^{* * *} \\
(5192.3)\end{array}$ & $\begin{array}{c}14123.6^{* * *} \\
(4423.1)\end{array}$ & $\begin{array}{c}14776.7^{* * *} \\
(5683.4)\end{array}$ & $\begin{array}{c}13609.2^{\text {**** }} \\
(4861.2)\end{array}$ \\
\hline Claim Size & $\begin{array}{l}238.1^{* * *} \\
(66.04)\end{array}$ & $\begin{array}{c}247.1^{* * * *} \\
(73.80)\end{array}$ & $\begin{array}{l}237.0^{* * *} \\
(61.75)\end{array}$ & $\begin{array}{l}241.8^{* * *} \\
(72.01)\end{array}$ \\
\hline Summer Flow & $\begin{array}{c}2.408^{*} \\
(1.378)\end{array}$ & $\begin{array}{c}0.869 \\
(1.014)\end{array}$ & $\begin{array}{c}2.240 \\
(1.455)\end{array}$ & $\begin{array}{c}0.827 \\
(1.047)\end{array}$ \\
\hline Flow Variability & $\begin{array}{c}99.50 \\
(122.6)\end{array}$ & $\begin{array}{c}261.2 \\
(193.0)\end{array}$ & $\begin{array}{c}115.7 \\
(122.6)\end{array}$ & $\begin{array}{c}234.2 \\
(195.1)\end{array}$ \\
\hline Roughness & $\begin{array}{l}-5.214 \\
(9.949)\end{array}$ & $\begin{array}{l}-63.56 \\
(61.02)\end{array}$ & $\begin{array}{c}0.773 \\
(20.17)\end{array}$ & $\begin{array}{l}-65.88 \\
(61.09)\end{array}$ \\
\hline Acres Loamy Soil & $\begin{array}{c}0.348 \\
(0.251)\end{array}$ & $\begin{array}{c}0.854 \\
(2.173)\end{array}$ & $\begin{array}{c}0.283 \\
(0.279)\end{array}$ & $\begin{array}{c}0.904 \\
(2.305)\end{array}$ \\
\hline Homesteaded Acres & $\begin{array}{l}-2.825^{* *} \\
(1.321)\end{array}$ & $\begin{array}{l}-2.045 \\
(1.517)\end{array}$ & $\begin{array}{l}-2.371^{*} \\
(1.430)\end{array}$ & $\begin{array}{c}-1.916 \\
(1.647)\end{array}$ \\
\hline Priority Controls & Yes & Yes & Yes & Yes \\
\hline Watershed Fixed Effects & No & Yes & No & Yes \\
\hline Decade Fixed Effects & No & No & Yes & Yes \\
\hline Observations & 550 & 550 & 550 & 550 \\
\hline$R^{2}$ & 0.323 & 0.449 & 0.326 & 0.451 \\
\hline
\end{tabular}


Table 7: Group Size and Ditch Investment

\begin{tabular}{|c|c|c|c|c|}
\hline & \multirow[t]{2}{*}{ (1) } & $(2)$ & (3) & \multirow[t]{2}{*}{ (4) } \\
\hline & & \multicolumn{2}{|c|}{$Y=$ DitchMeters } & \\
\hline Division 1 & $\begin{array}{l}4811.2 * \\
(2804.0)\end{array}$ & $\begin{array}{c}-43782.1 \\
(229041.6)\end{array}$ & $\begin{array}{c}4042.3 \\
(2579.9)\end{array}$ & $\begin{array}{c}1415.2 \\
(8608.8)\end{array}$ \\
\hline Group Size & $\begin{array}{c}130.1 \\
(313.4)\end{array}$ & $\begin{array}{c}612.0 \\
(442.3)\end{array}$ & $\begin{array}{c}167.2 \\
(328.0)\end{array}$ & $\begin{array}{c}548.7 \\
(452.6)\end{array}$ \\
\hline Division $1 \times$ Group Size & $\begin{array}{l}3022.0 * * \\
(1263.5)\end{array}$ & $\begin{array}{l}2138.9 * \\
(1161.9)\end{array}$ & $\begin{array}{c}2911.3 * * \\
(1327.0)\end{array}$ & $\begin{array}{l}2153.2 * \\
(1202.7)\end{array}$ \\
\hline Claim Size & $\begin{array}{c}245.2 * * * \\
(59.09)\end{array}$ & $\begin{array}{c}254.0 * * * \\
(69.70)\end{array}$ & $\begin{array}{c}248.7 * * * \\
(55.23)\end{array}$ & $\begin{array}{c}249.0 * * * \\
(68.47)\end{array}$ \\
\hline Summer Flow & $\begin{array}{c}1.186 \\
(1.142)\end{array}$ & $\begin{array}{c}0.486 \\
(0.968)\end{array}$ & $\begin{array}{c}1.835 \\
(1.420)\end{array}$ & $\begin{array}{c}0.447 \\
(0.977)\end{array}$ \\
\hline Flow Variability & $\begin{array}{c}146.7 \\
(133.4)\end{array}$ & $\begin{array}{l}330.0 * \\
(187.6)\end{array}$ & $\begin{array}{c}143.6 \\
(127.2)\end{array}$ & $\begin{array}{c}305.9 \\
(191.0)\end{array}$ \\
\hline Roughness & $\begin{array}{c}19.82 \\
(31.47)\end{array}$ & $\begin{array}{l}-53.55 \\
(57.01)\end{array}$ & $\begin{array}{c}20.08 \\
(31.05)\end{array}$ & $\begin{array}{c}-54.42 \\
(58.73)\end{array}$ \\
\hline Acres Loamy Soil & $\begin{array}{l}0.431 * \\
(0.231)\end{array}$ & $\begin{array}{c}0.922 \\
(2.264)\end{array}$ & $\begin{array}{c}0.376 \\
(0.291)\end{array}$ & $\begin{array}{c}0.961 \\
(2.297)\end{array}$ \\
\hline Claim Year & $\begin{array}{l}-1.436 \\
(4.799)\end{array}$ & $\begin{array}{c}24.76 \\
(123.1)\end{array}$ & $\begin{array}{l}-3.209 \\
(5.153)\end{array}$ & \\
\hline Homesteaded Acres & & $\begin{array}{c}-1.683 \\
(1.553)\end{array}$ & $\begin{array}{l}-1.912 \\
(1.384)\end{array}$ & $\begin{array}{l}-1.627 \\
(1.567)\end{array}$ \\
\hline Priority Controls & Yes & Yes & Yes & Yes \\
\hline Watershed Fixed Effects & No & Yes & No & Yes \\
\hline Decade Fixed Effects & No & No & Yes & Yes \\
\hline Observations & 550 & 550 & 550 & 550 \\
\hline$R^{2}$ & 0.341 & 0.463 & 0.347 & 0.465 \\
\hline
\end{tabular}


Table 8: Coordination via Clustering of Water Rights Claims and Purchase (Cache La Poudre Drainage).

\begin{tabular}{|c|c|c|c|c|}
\hline CANAL & $\begin{array}{l}\text { PRIORITY } \\
\text { DATES }\end{array}$ & PRIORITIES & SOURCES & SIZE $\mathrm{Ft}^{3} / \mathrm{SEC}$ \\
\hline \multirow{7}{*}{ Larimer County Canal } & Mar 1,1862 & 5 & Pioneer Ditch & 10.77 \\
\hline & Sept 15,1864 & 12 & Pioneer Ditch & 13.89 \\
\hline & Mar 15,1868 & 28 & Canyon Ditch & 4.66 \\
\hline & Mar 20,1873 & 56 & Canyon Ditch & 4 \\
\hline & Apr 1,1878 & 84 & Smith Ditch & 7.23 \\
\hline & Apr 25,1881 & 100 & Original & 463 \\
\hline & & & TOTAL & 503.55 \\
\hline \multirow[t]{5}{*}{ Jackson Ditch } & June 10,1861 & 3 & Original & 11.67 \\
\hline & Oct 21,1870 & 36 & Original & 14.42 \\
\hline & Sept 15,1873 & 67 & Original & 12.13 \\
\hline & July 15,1879 & 91 & Original & 12.7 \\
\hline & & & TOTAL & 50.92 \\
\hline \multirow[t]{6}{*}{ Larimer and Weld Canal } & June 1,1864 & 10 & No.10 Ditch & 3 \\
\hline & Apr 1,1867 & 21 & No.10 Ditch & 16.67 \\
\hline & Sept 20,1871 & 45 & No.10 Ditch & 75 \\
\hline & Jan 15,1875 & 73 & No.10 Ditch & 54.33 \\
\hline & Sept ,1878 & 88 & Original & 571 \\
\hline & & & TOTAL & 720 \\
\hline \multirow[t]{5}{*}{$\begin{array}{l}\text { Greeley Union Colony Canal } \\
\text { No.2 }\end{array}$} & Oct 25,1870 & 37 & Original & 110 \\
\hline & Sept 15,1871 & 44 & Original & 170 \\
\hline & Nov 10,1874 & 72 & Original & 184 \\
\hline & Sept 15,1877 & 83 & Original & 121 \\
\hline & & & TOTAL & 585 \\
\hline \multirow[t]{5}{*}{$\begin{array}{l}\text { Greeley Union Colony Canal } \\
\text { No.3 }\end{array}$} & April 1,1870 & 35 & Original & 52 \\
\hline & Oct 1,1871 & 46 & Original & 41 \\
\hline & July 15,1872 & 50 & Original & 63.13 \\
\hline & May 15,1873 & 59 & Original & 16.66 \\
\hline & & & TOTAL & 172.79 \\
\hline
\end{tabular}

Source: Hemphill (1922, pp. 14-15.). 
Table 9: Irrigated vs. Riparian Land (2015 \$)

\begin{tabular}{lrr|rr}
\hline & \multicolumn{2}{c|}{ Division 1 } & \multicolumn{2}{c}{ Division 3 } \\
& Riparian & Non-Riparian & Riparian & Non-Riparian \\
\hline Irrigated Acres & 337,917 & 408,275 & 72,350 & 138,277 \\
Total Farm Income & $\$ 183,310,710$ & $\$ 228,480,781$ & $\$ 30,948,204$ & $\$ 58,583,937$ \\
Median Farm Size & 147 & 760 & 99 & 262 \\
Average Income Per Acre & $\$ 527.50$ & $\$ 548.32$ & $\$ 601.67$ & $\$ 600.10$ \\
& $(3.28)$ & $(3.05)$ & $(14.64)$ & $(12.36)$ \\
\hline
\end{tabular}

Standard error of the mean reported in parentheses for Income Per Acre

Table 10: The Effect of Coordination on Income Per Acre

\begin{tabular}{lc|c}
\hline & Division 1 & Division 3 \\
\hline Reduced Form $^{\mathrm{a}}$ & $105.7^{* * * *}$ & -7.934 \\
& $(28.60)$ & $(51.50)$ \\
Back of the Envelope & $132.20^{* * *}$ & -10.53 \\
& $(15.06)$ & $(29.04)$ \\
SUR $^{\mathrm{c}}$ & $109.12^{* * *}$ & -12.32 \\
& $(38.16)$ & $(49.74)$ \\
\hline
\end{tabular}

\footnotetext{
${ }^{\text {a }}$ Spatial HAC GMM standard errors reported in parentheses

b Spatial HAC GMM standard errors estimated equation-by-equation. Standard error of the prediction obtained using the delta method and assuming errors are uncorrelated across equations ${ }^{c}$ Correlated standard errors reported in parentheses ${ }^{*} p<.1,{ }^{* *} p<.05,{ }^{* * *} p<.01$
}

Table 11: Contribution of Agriculture to State/Territory Income

\begin{tabular}{|c|c|c|c|c|c|c|}
\hline & \multicolumn{3}{|c|}{1910} & \multicolumn{3}{|c|}{1930} \\
\hline & $\begin{array}{r}\text { Irrigated Crop } \\
\text { Value }\end{array}$ & $\begin{array}{l}\% \text { of State } \\
\text { Income }\end{array}$ & $\begin{array}{r}\text { No-Rip \% } \\
\text { of State } \\
\text { Income }\end{array}$ & $\begin{array}{r}\text { Irrigated Crop } \\
\text { Value }\end{array}$ & $\begin{array}{r}\% \text { of State } \\
\text { Income }\end{array}$ & $\begin{array}{r}\text { No-Rip \% } \\
\text { of State } \\
\text { Income }\end{array}$ \\
\hline Arizona & $\$ 109,088,226$ & $7.8 \%$ & $4.4 \%$ & $\$ 218,429,933$ & $6.8 \%$ & $3.9 \%$ \\
\hline California & $\$ 1,198,335,054$ & $5.4 \%$ & $3.1 \%$ & $\$ 4,730,240,019$ & $6.6 \%$ & $3.8 \%$ \\
\hline Colorado & $\$ 955,887,896$ & $15.4 \%$ & $8.8 \%$ & $\$ 1,216,338,604$ & $14.4 \%$ & $8.2 \%$ \\
\hline Idaho & $\$ 411,487,005$ & $26.0 \%$ & $14.8 \%$ & $\$ 1,176,322,174$ & $38.2 \%$ & $21.8 \%$ \\
\hline Montana & $\$ 357,644,113$ & $12.9 \%$ & $7.3 \%$ & $\$ 543,002,901$ & $14.2 \%$ & $8.1 \%$ \\
\hline Nevada & $\$ 129,481,278$ & $19.7 \%$ & $11.3 \%$ & $\$ 199,548,712$ & $18.5 \%$ & $10.6 \%$ \\
\hline New Mexico & $\$ 132,129,974$ & $9.2 \%$ & $5.2 \%$ & $\$ 282,107,719$ & $14.2 \%$ & $8.1 \%$ \\
\hline Oregon & $\$ 182,079,466$ & $3.9 \%$ & $2.2 \%$ & $\$ 425,281,996$ & $5.2 \%$ & $3.0 \%$ \\
\hline Utah & $\$ 355,860,090$ & $15.1 \%$ & $8.6 \%$ & $\$ 526,011,917$ & $14.8 \%$ & $8.4 \%$ \\
\hline Washington & $\$ 182,766,338$ & $2.9 \%$ & $1.7 \%$ & $\$ 896,351,083$ & $6.2 \%$ & $3.5 \%$ \\
\hline Wyoming & $\$ 182,849,867$ & $13.7 \%$ & $7.8 \%$ & $\$ 355,530,834$ & $19.1 \%$ & $10.9 \%$ \\
\hline
\end{tabular}

Notes: 1) All dollar amounts are reported in 2015 dollars. 2) Territory income is used for states prior to statehood. 3) Calculations are detailed in footnote 46 . 
Figure 1: Irrigation Networks in Arid Regions, West of the $100^{\text {th }}$ Meridian

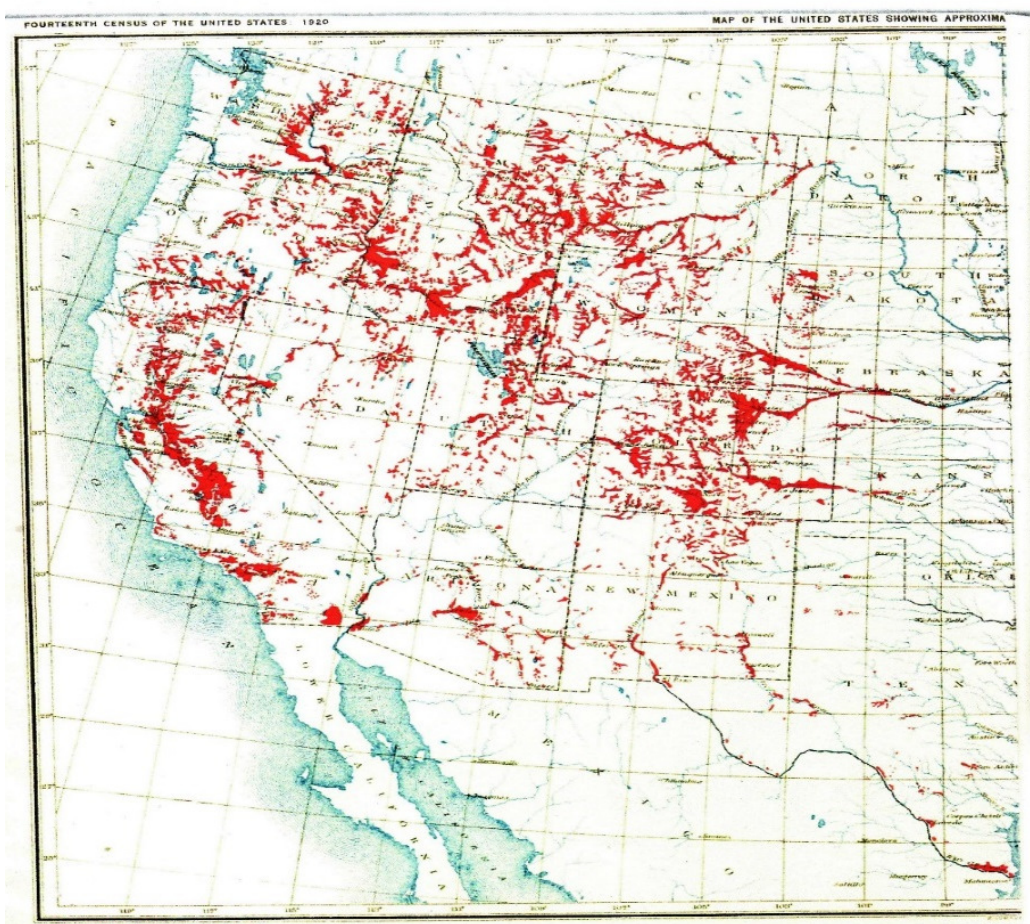

Source: US Census Bureau $(1922,1)$.

Figure 2: Prior Appropriation West of the $100^{\text {th }}$ Meridian

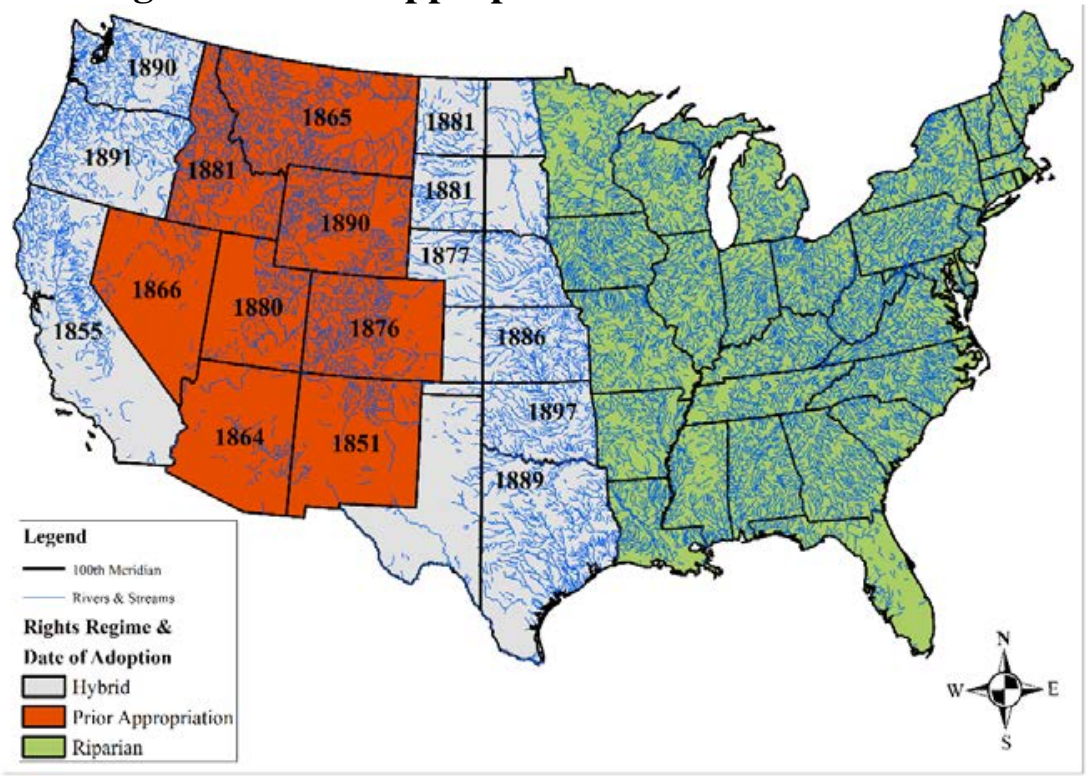


Figure 3: Water Resources and Terrain in Colorado

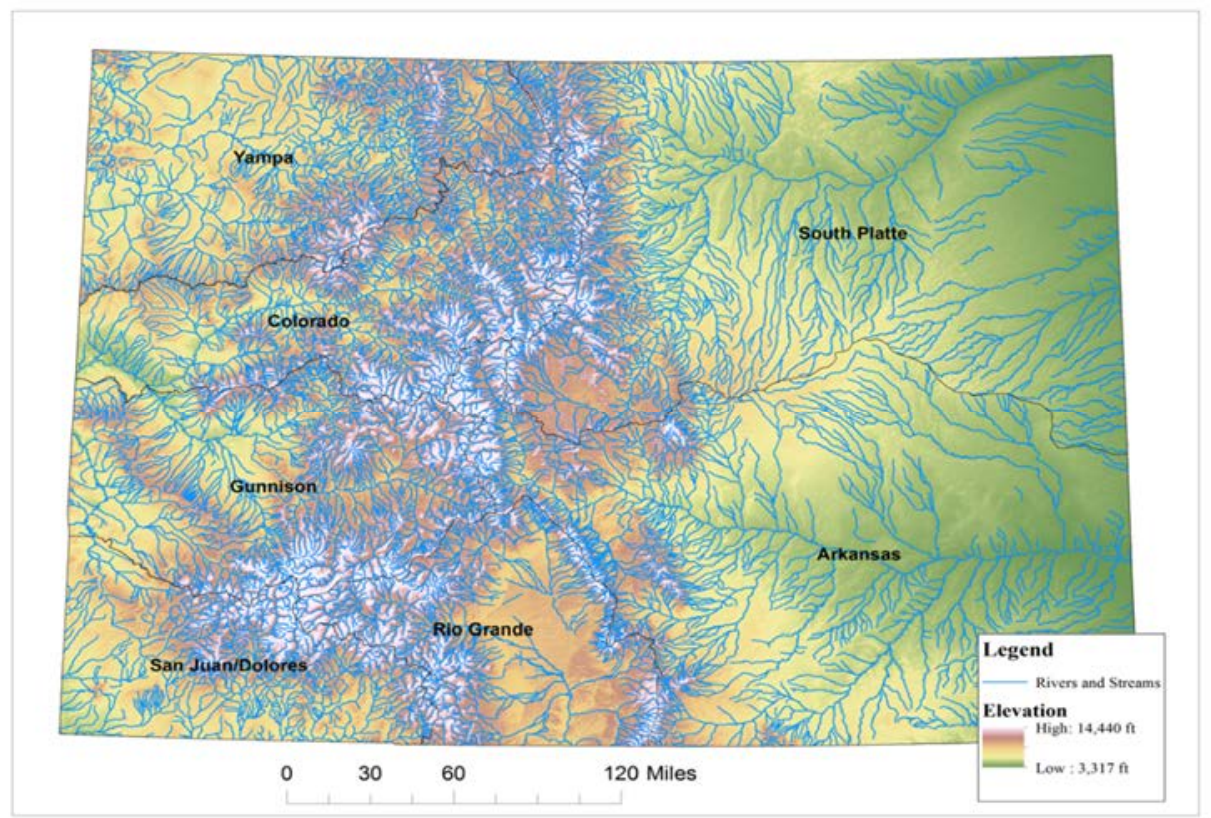

Figure 4: The Timing and Volume of Water Claims in Colorado

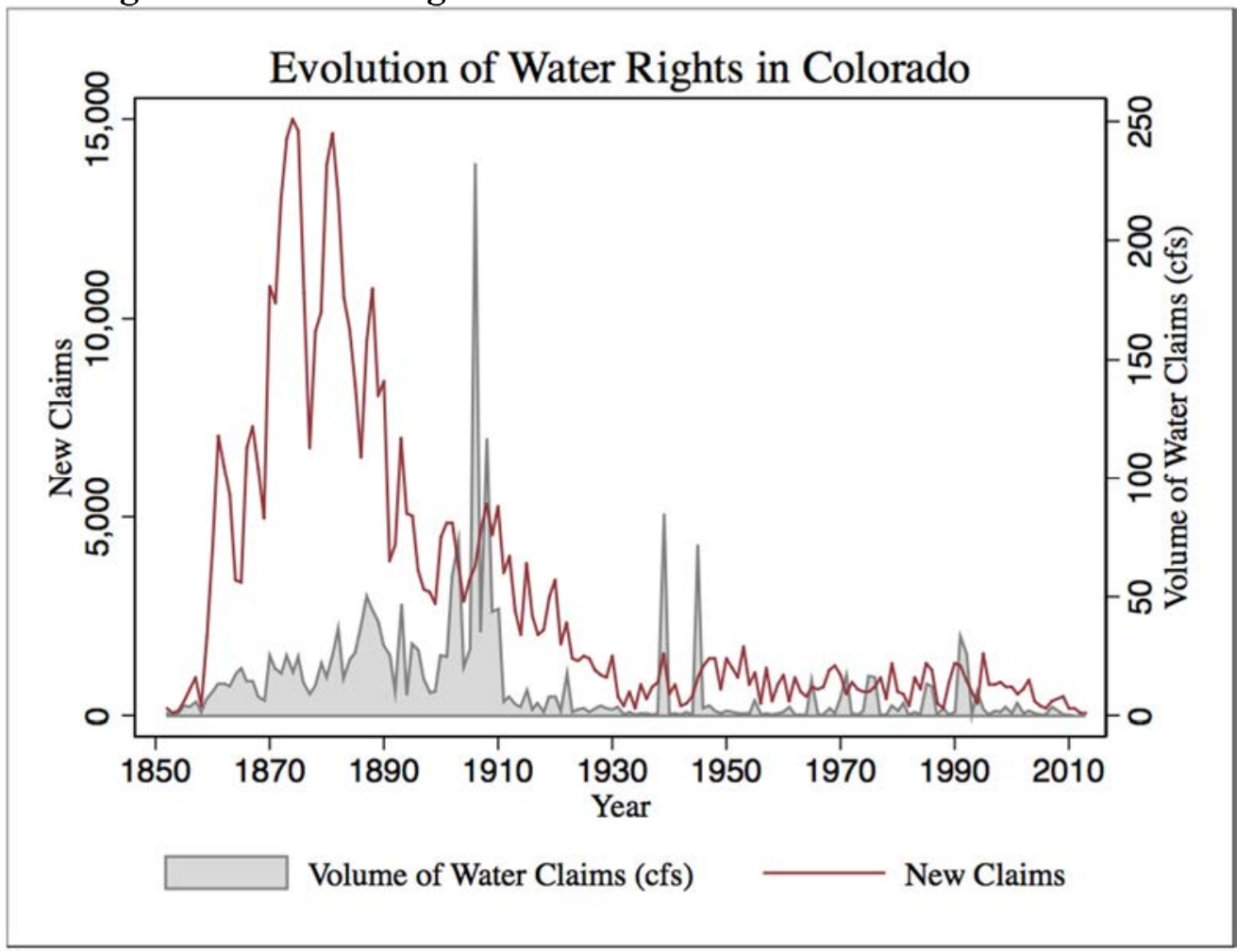


Figure 5: Potential Homestead Claims and Actual Irrigation Infrastructure

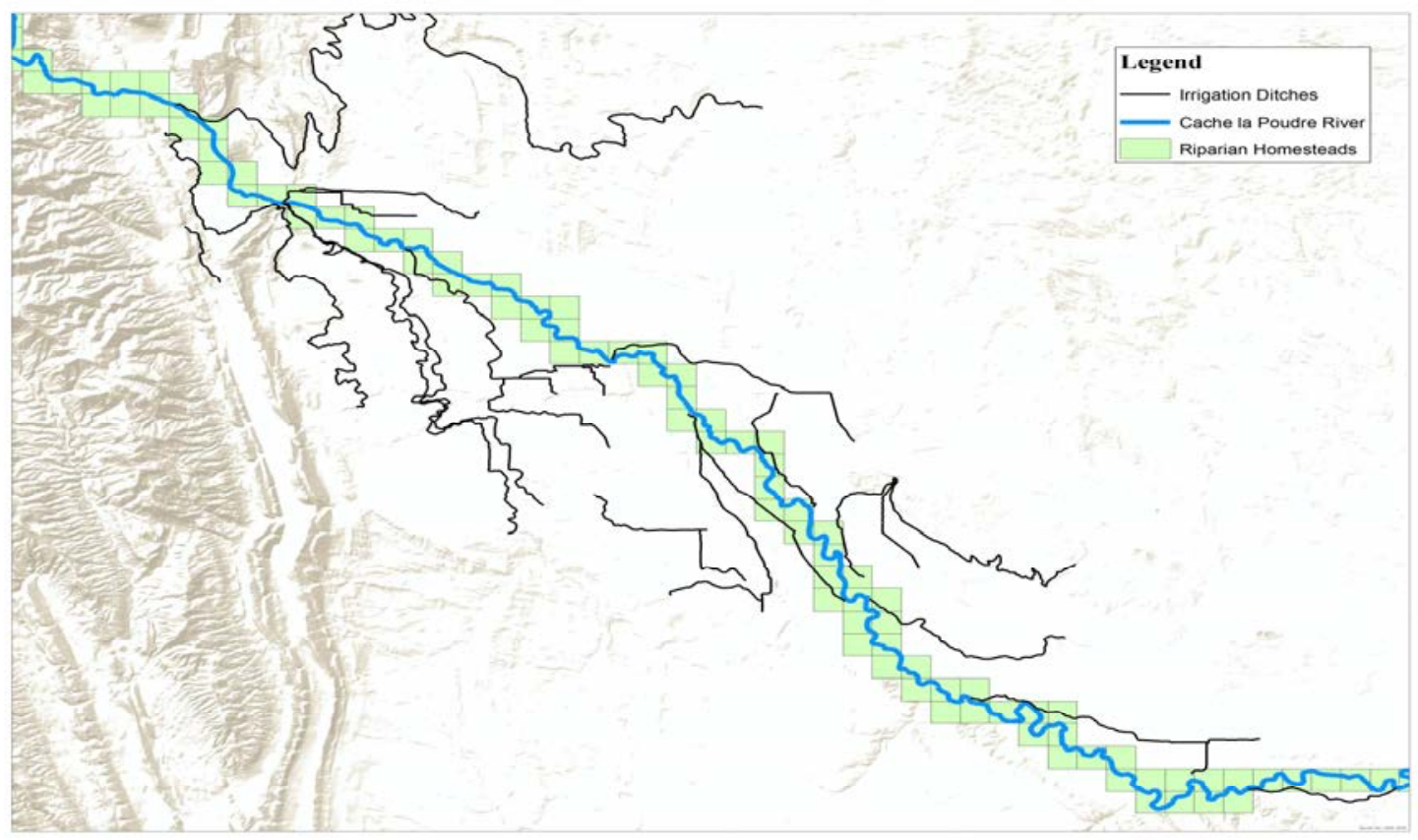

Figure 6: Possible and Actual Claim Sites
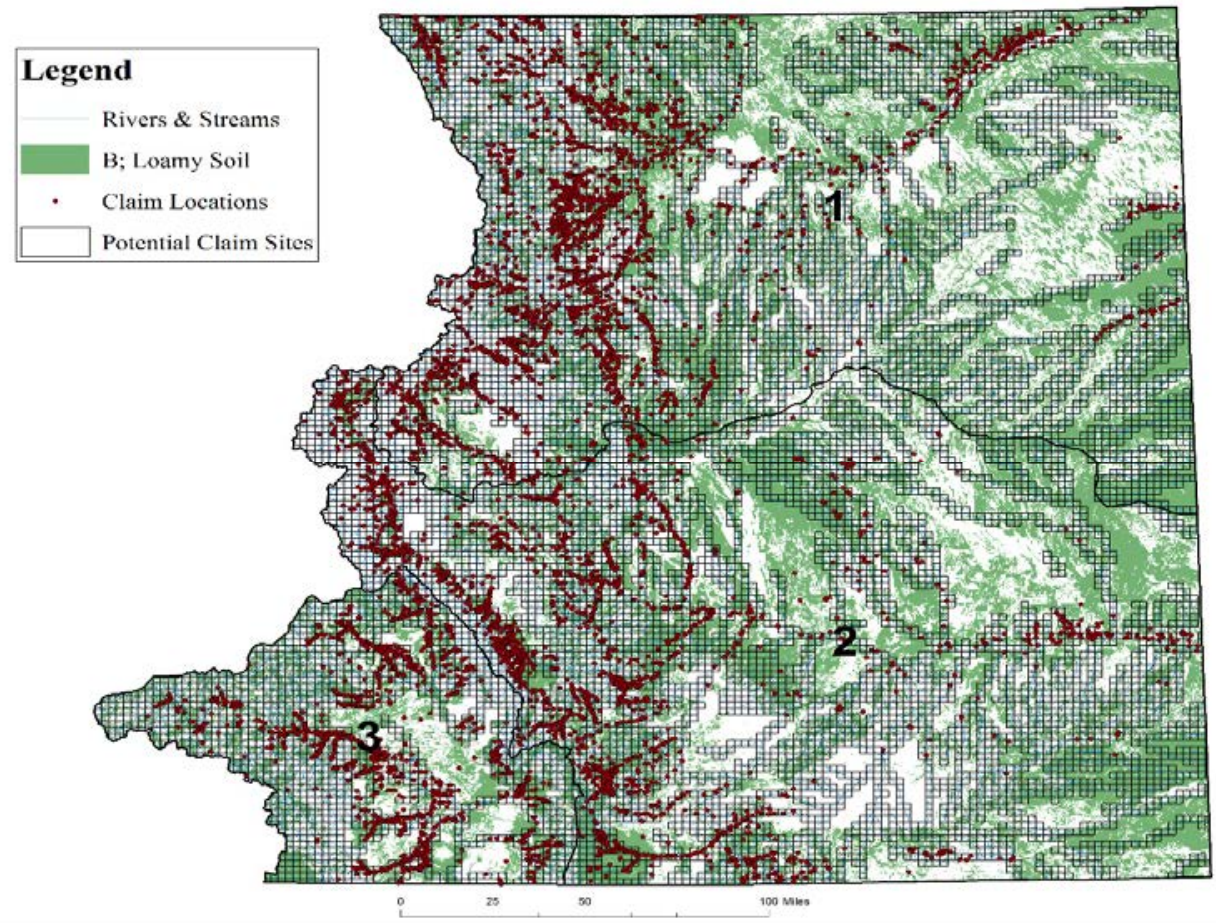
Figure 7: The Information-Resource Trade-Off

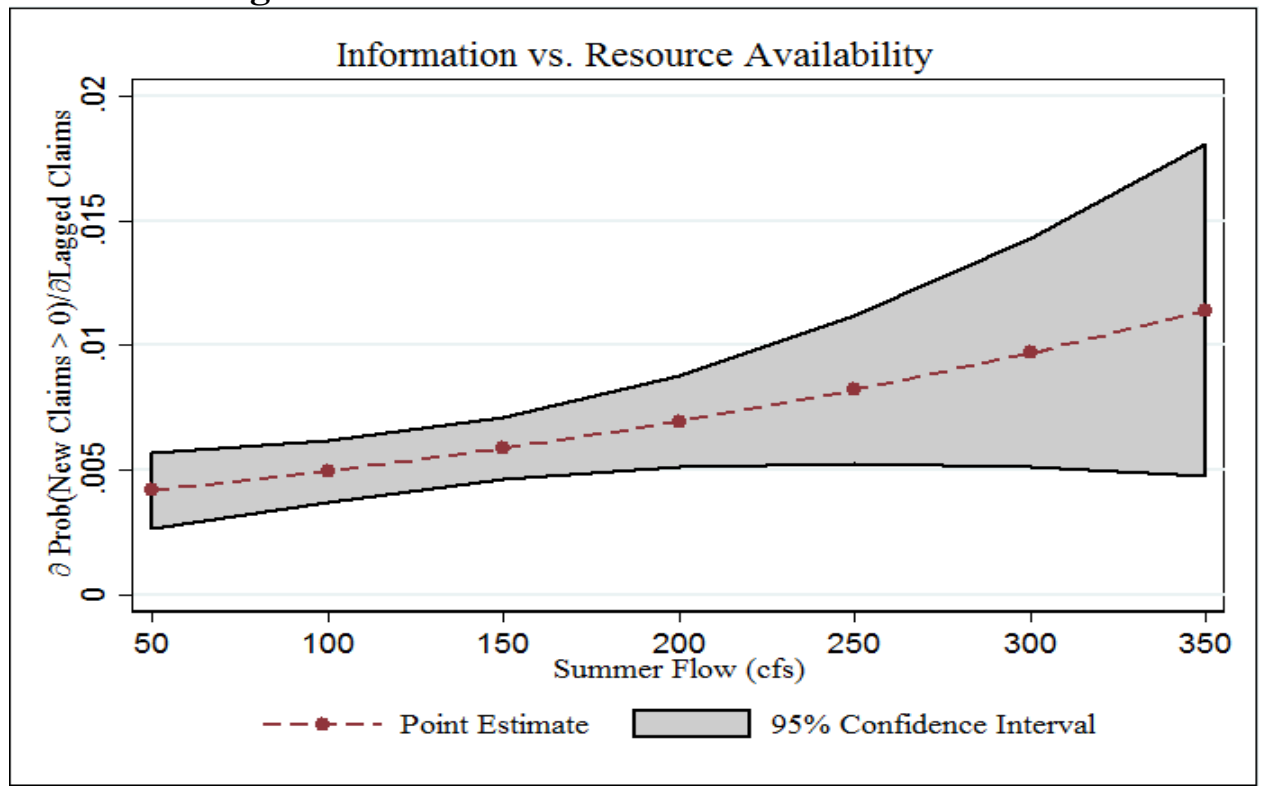

Figure 8: Marginal Effects of Priority on Cooperation

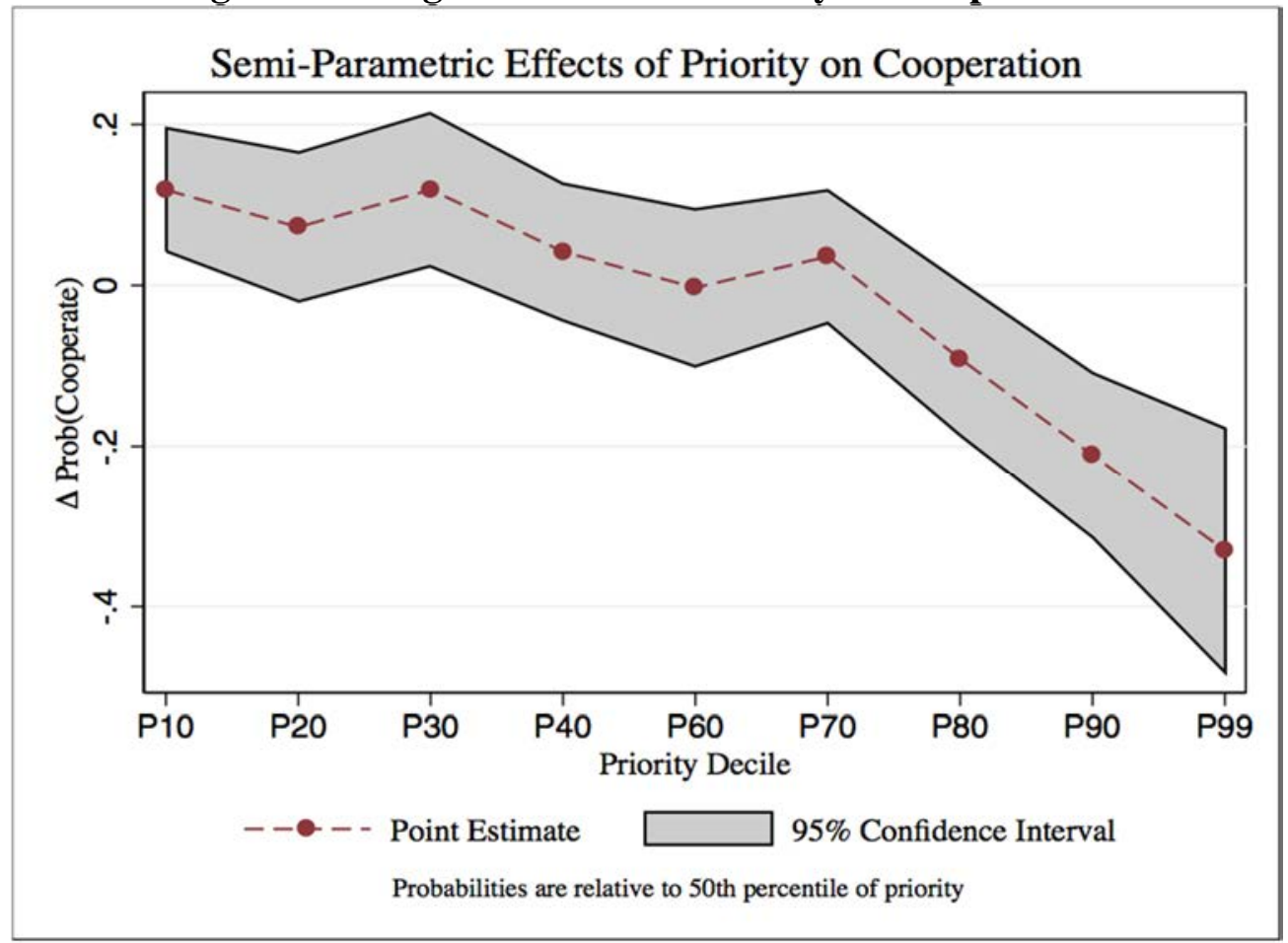


Figure 9: Riparian and Arable Lands in Eastern Colorado

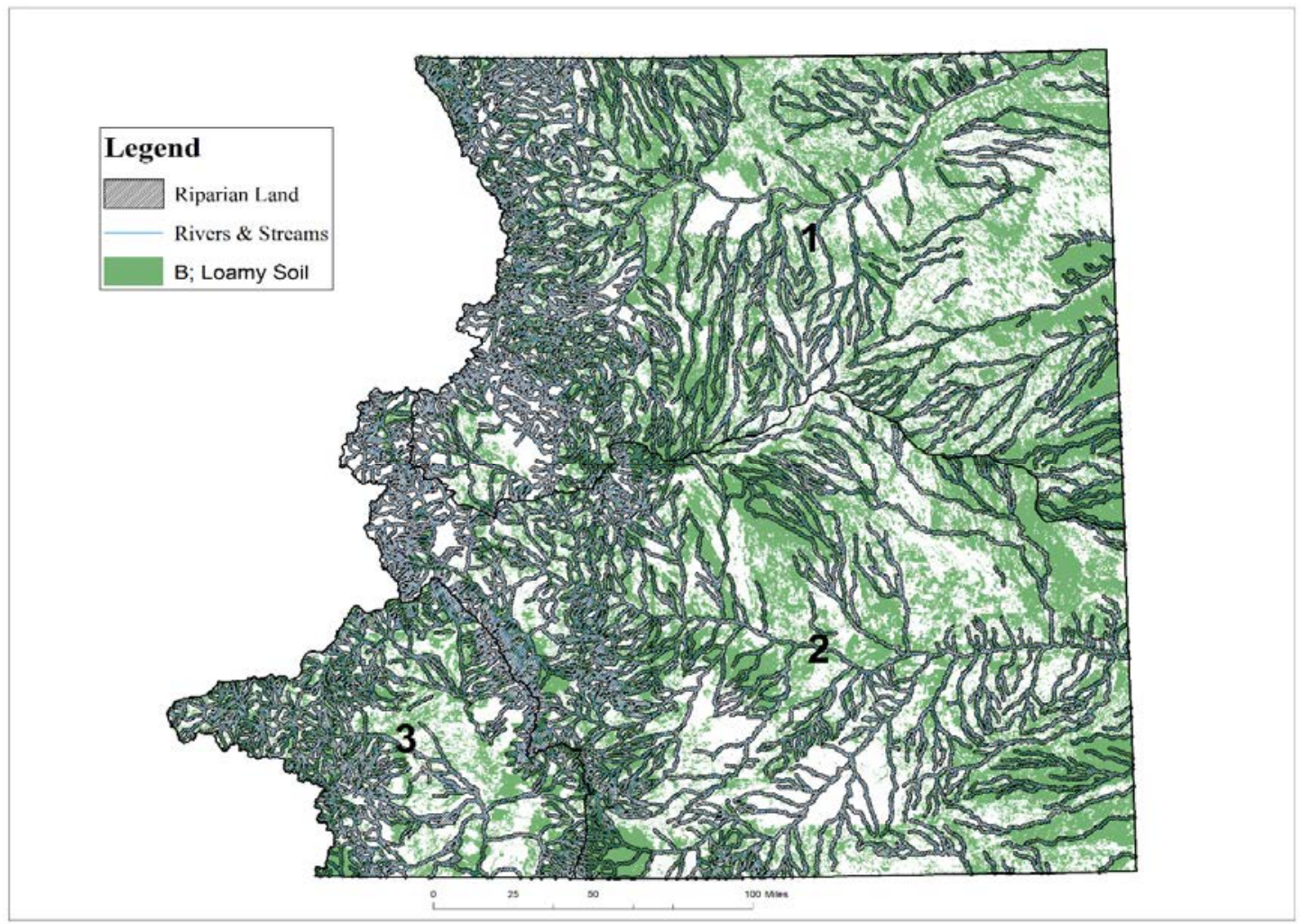

Figure 10: Riparian and Irrigated Land, Divisions 1, 3
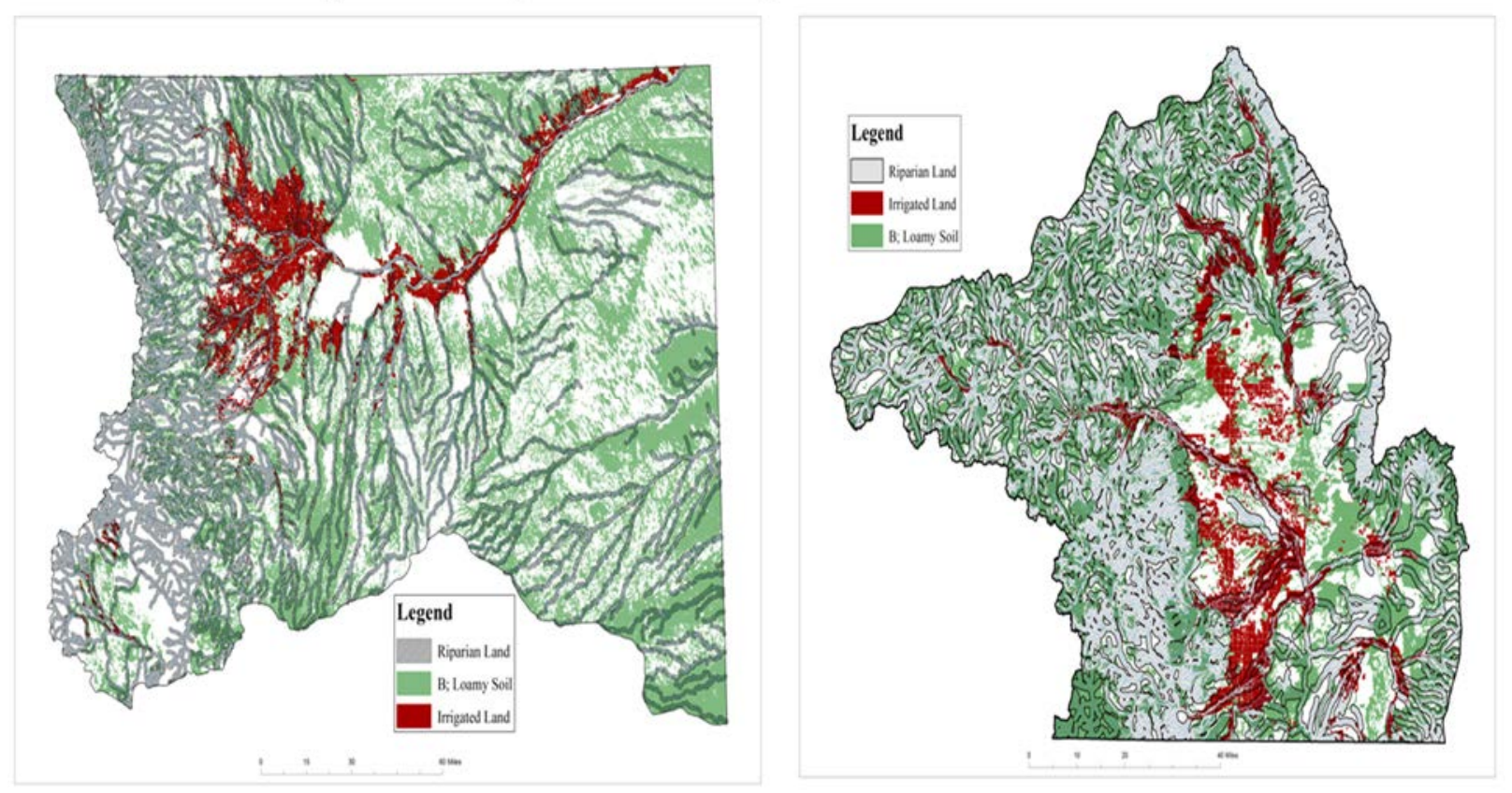


\section{Appendix A: GIS Data Construction}

GIS Hydrologic data on basins, stream names, and network characteristics come from the National Hydrography Data Set (NHD). The NHD has been programmed as a linear network geodatabase that allows for tracing elements' relative positions along the network, a feature which we exploit. Estimates of stream flow across this network were obtained from NHDPLUS V2. ${ }^{1}$ Elevation data are measured at 30-meter intervals and come from the National Elevation Dataset. These data are used to compute the slope and standard deviation of slope in the neighborhood of each right. Our soil data are from the USDA Soil Survey Geographic Database (SSURGO).

We calculate measures of resource quality relating to both land and streams for each grid square. We calculate the average and standard deviation of slope in each grid square and construct the variable roughness, which is the average slope multiplied by the standard deviation of slope. ${ }^{2}$ We use the SSURGO data to calculate the number of acres of soil in each hydrologic soil group defined by the USDA. This measure of soil quality is based on the structure of the soil itself rather than its current water content. This allows us to use a current GIS measure of soil quality to estimate historical soil quality over the period of our study. We focus on Soil Group B, which is comprised primarily of loamy soil and is the most productive for agriculture. We also calculate the total area (in acres) of the watershed that a square resides in using the HUC8 classification of watersheds from the NHD.

We perform a network trace to locate each square along the stream network defined by the NHD and use this location to create a variety of variables relating to the water resource itself. We calculate the distance from each grid square to the head of the stream it lies on (as delineated by the NHD). ${ }^{3}$ The NHDPlus V2 dataset created by Horizon Systems Corporation provides monthly and annual stream flow estimates for each stream on the NHD network. We use this information to create a measure of the total flow across May through August. ${ }^{4}$ We combine these contemporary estimates of stream flow with contemporary and historical estimate of precipitation from the PRISM dataset and elevation data from the NED to estimate a model for predicting historical flows along the entire stream network. We use these estimates to calculate the average summer flow and standard deviation of flow from 1890 to $2000 .^{5}$ The variable Summer Flow is the century-long average of total summer flow, based on flows in May through August of each year. The variable Flow Variability is the standard deviation of stream flow for a given reach over this period. Details on the hydrologic and econometric models underlying these calculations are available upon request.

\footnotetext{
${ }^{1}$ NHDPLUS, provided by the Horizon Systems Corporation, is an augmented version of the National Hydrography dataset that has been combined with the National Elevation Data Set and the PRISM climate dataset to produce a variety of flow-related statistics across the entire stream network.

${ }^{2}$ This construction captures the fact that both steeper terrain and more variable terrain contribute to rugged topography and make various forms of development more difficult.

${ }^{3}$ For most streams the entire length of the stream is used. Major rivers are divided into reaches within the NHD, and we maintain this division because we believe it reflects the fact that relative positive along major rivers is less critical than relative position along smaller streams.

${ }^{4}$ These are the months during which irrigation is critical to support crop growth.

${ }^{5}$ PRISM data on historical precipitation are only available back to 1890. Rather than clip our dataset and having yearly estimates of flow, we use century long averages to capture average stream characteristics.
} 
Appendix Table B1: Estimated Average Partial Effects on Prob (New Claims)

\begin{tabular}{|c|c|c|c|}
\hline \multirow{2}{*}{$\frac{\partial \operatorname{Pr}(\text { NewClaims }>0)}{\partial x}$} & \multirow{2}{*}{\multicolumn{3}{|c|}{$\begin{array}{l}(1) \\
\text { Probit Estimates, } Y=1(\text { New Claims } \\
\text { jt }\end{array}$}} \\
\hline & & & \\
\hline 1(Lagged Claims $>0)$ & $\begin{array}{l}0.0456^{* * *} \\
(0.00490)\end{array}$ & $\begin{array}{l}0.0459^{* * *} \\
(0.00492)\end{array}$ & $\begin{array}{l}0.0365^{* * * *} \\
(0.00420)\end{array}$ \\
\hline Summer Flow & $\begin{array}{r}0.00000590^{* * * *} \\
(0.00000186)\end{array}$ & $\begin{array}{r}0.00000720^{* * *} \\
(0.00000209)\end{array}$ & $\begin{array}{r}0.00000656^{* * * *} \\
(0.00000201)\end{array}$ \\
\hline Flow Variability & $\begin{array}{r}-0.00000228 \\
(0.00000459)\end{array}$ & $\begin{array}{r}-0.00000271 \\
(0.00000482)\end{array}$ & $\begin{array}{l}-0.00000364 \\
(0.00000479)\end{array}$ \\
\hline Drought & $\begin{array}{r}-0.00247^{* * *} \\
(0.000341)\end{array}$ & $\begin{array}{r}-0.00246^{* * *} \\
(0.000353)\end{array}$ & $\begin{array}{r}-0.00186^{* * *} \\
(0.000325)\end{array}$ \\
\hline Roughness & $\begin{array}{r}-0.00000254^{* * *} \\
(0.000000911)\end{array}$ & $\begin{array}{r}-0.00000284^{* * *} \\
(0.000000928)\end{array}$ & $\begin{array}{r}-0.00000386^{* * * *} \\
(0.000000986)\end{array}$ \\
\hline Acres Loamy Soil & $\begin{array}{r}0.000000115 \\
(0.000000468)\end{array}$ & $\begin{array}{r}0.000000126 \\
(0.000000475)\end{array}$ & $\begin{array}{r}0.00000133^{* *} \\
(0.000000535)\end{array}$ \\
\hline Watershed Acres & $\begin{array}{r}0.000000968^{* * *} \\
(0.000000202)\end{array}$ & $\begin{array}{l}0.00000107^{* * *} \\
(0.000000204)\end{array}$ & $\begin{array}{l}0.00000100^{* * *} \\
(0.000000211)\end{array}$ \\
\hline Homestead Claims $\mathrm{t}-1_{1}$ & $\begin{array}{l}0.000120^{* * * *} \\
(0.0000202)\end{array}$ & $\begin{array}{l}0.000124^{* * *} \\
(0.0000209)\end{array}$ & $\begin{array}{l}0.000121^{* * * *} \\
(0.0000289)\end{array}$ \\
\hline 1(Initial Claims >0) & $\begin{array}{l}0.0112^{* * *} \\
(0.00139)\end{array}$ & $\begin{array}{l}0.0113^{* * *} \\
(0.00132)\end{array}$ & $\begin{array}{r}0.00894^{* * * *} \\
(0.00104)\end{array}$ \\
\hline $\begin{array}{l}\text { Total Water Claimed } \\
\text { (cfs) }\end{array}$ & & $\begin{array}{r}-2.04 \mathrm{e}-08^{* * *} \\
(6.23 \mathrm{e}-09)\end{array}$ & $\begin{array}{r}2.13 \mathrm{e}-08^{* * *} \\
(6.17 \mathrm{e}-09)\end{array}$ \\
\hline $\begin{array}{l}\text { Total Homesteaded } \\
\text { Acres }\end{array}$ & & & $\begin{array}{r}-0.000000122^{* * * *}(2.19 \mathrm{e}-08) \\
\end{array}$ \\
\hline $\mathrm{N}$ & 248,745 & 248,745 & 248,745 \\
\hline
\end{tabular}


Table B2: Coefficient Estimates from Fixed Effects Poisson

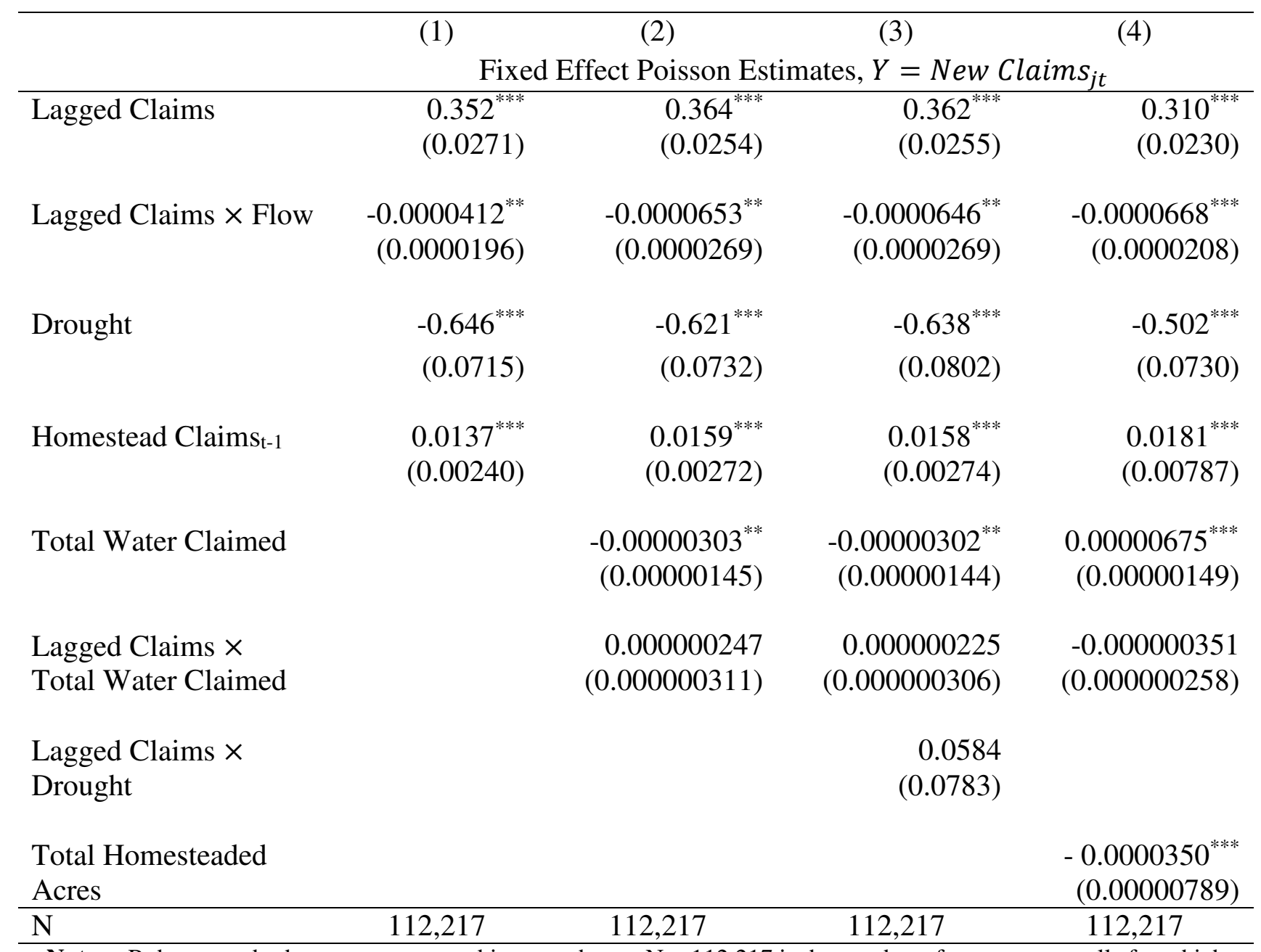

Notes: Robust standard errors are reported in parentheses. $\mathrm{N}=112,217$ is the number of stream-year cells for which we have overlapping data on all covariates. Streams that never receive a claim are dropped from the fixed effects specification* $\mathrm{p}<: 1, * * \mathrm{p}<: 05, * * * \mathrm{p}<: 01$ 
Table B3: Coefficient Estimates from Fixed Effects Logit

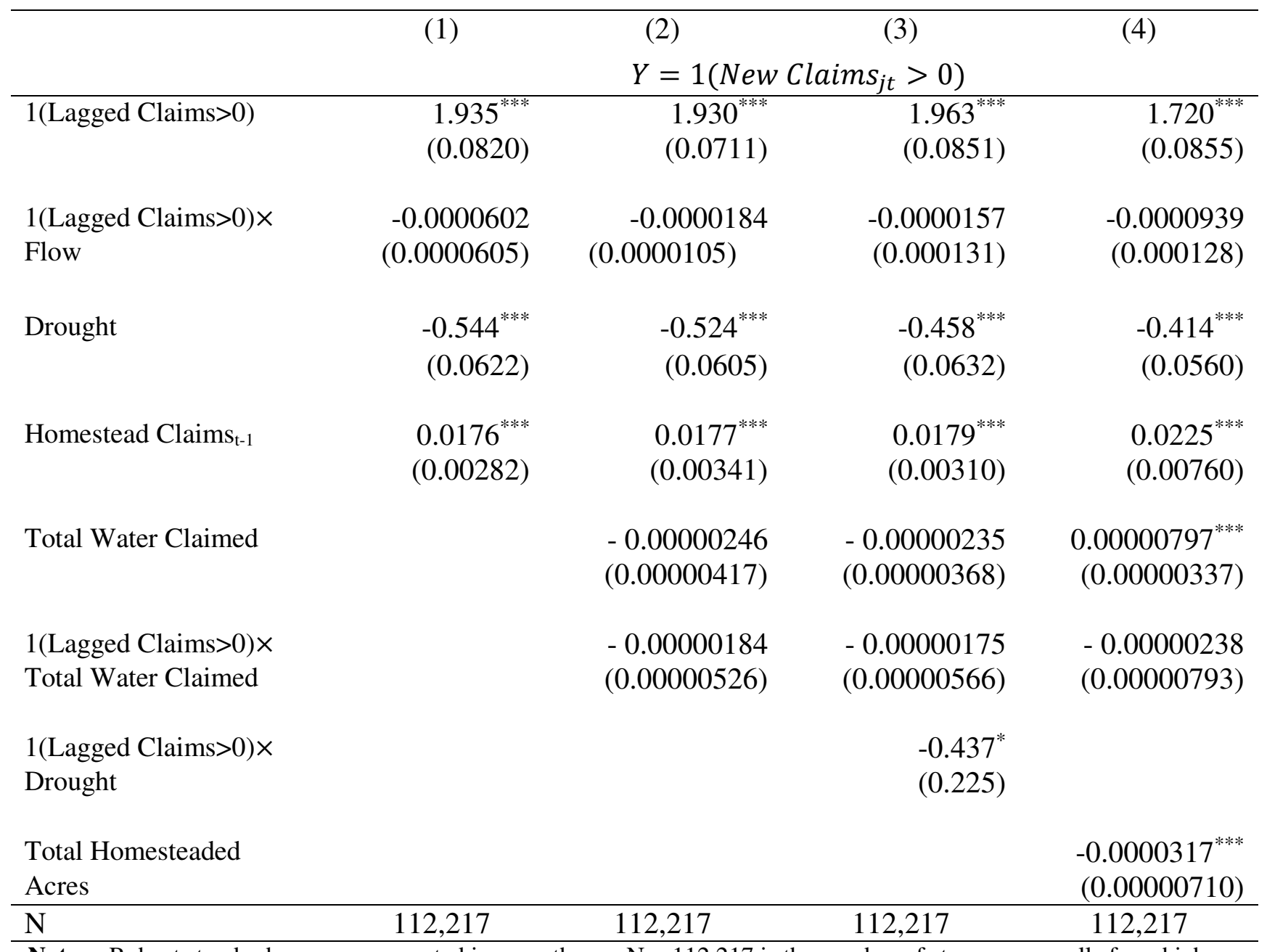

Notes: Robust standard errors are reported in parentheses. $\mathrm{N}=112,217$ is the number of stream-year cells for which we have overlapping data on all covariates. Streams that never receive a claim are dropped from the fixed effects specification* $\mathrm{p}<: 1, * * \mathrm{p}<: 05, * * * \mathrm{p}<: 01$ 
Table B4: Marginal Effects of Priority on Cooperation

\begin{tabular}{|c|c|c|c|c|}
\hline$Y=\mathrm{CoOp}$ & \multicolumn{2}{|c|}{ Divisions 1-3 } & Division1 & Division3 \\
\hline $1^{\text {st }}$ Priority Decile & $\begin{array}{l}0.123^{* * *} \\
(0.0359)\end{array}$ & $\begin{array}{c}0.119^{* * *} \\
(0.0390)\end{array}$ & $\begin{array}{r}0.0207 \\
(0.0779)\end{array}$ & $\begin{array}{c}0.194^{* *} \\
(0.0797)\end{array}$ \\
\hline $2^{\text {nd }}$ Priority Decile & $\begin{array}{r}0.0541 \\
(0.0456)\end{array}$ & $\begin{array}{r}0.0725 \\
(0.0472)\end{array}$ & $\begin{array}{r}0.0154 \\
(0.0929)\end{array}$ & $\begin{array}{r}0.123 \\
(0.0999)\end{array}$ \\
\hline $3^{\text {rd }}$ Priority Decile & $\begin{array}{r}0.0882^{*} \\
(0.0468)\end{array}$ & $\begin{array}{r}0.119^{* *} \\
(0.0488)\end{array}$ & $\begin{array}{r}-0.00675 \\
(0.0861)\end{array}$ & $\begin{array}{r}0.202^{*} \\
(0.115)\end{array}$ \\
\hline $4^{\text {th }}$ Priority Decile & $\begin{array}{r}0.0318 \\
(0.0432)\end{array}$ & $\begin{array}{r}0.0419 \\
(0.0431)\end{array}$ & $\begin{array}{r}0.0624 \\
(0.0855)\end{array}$ & $\begin{array}{r}0.00619 \\
(0.0905)\end{array}$ \\
\hline $6^{\text {th }}$ Priority Decile & $\begin{array}{r}-0.0154 \\
(0.0518)\end{array}$ & $\begin{array}{c}-0.00285 \\
(0.0495)\end{array}$ & $\begin{array}{r}-0.0558 \\
(0.0698)\end{array}$ & $\begin{array}{r}0.0391 \\
(0.0995)\end{array}$ \\
\hline $7^{\text {th }}$ Priority Decile & $\begin{array}{r}0.0366 \\
(0.0401)\end{array}$ & $\begin{array}{r}0.0359 \\
(0.0421)\end{array}$ & $\begin{array}{r}-0.0761 \\
(0.0674)\end{array}$ & $\begin{array}{r}0.146 \\
(0.104)\end{array}$ \\
\hline $8^{\text {th }}$ Priority Decile & $\begin{array}{r}-0.0591 \\
(0.0447)\end{array}$ & $\begin{array}{l}-0.0910^{*} \\
(0.0485)\end{array}$ & $\begin{array}{c}-0.181^{* * *} \\
(0.0753)\end{array}$ & $\begin{array}{r}-0.0301 \\
(0.0900)\end{array}$ \\
\hline $9^{\text {th }}$ Priority Decile & $\begin{array}{c}-0.160^{* * * *} \\
(0.0465)\end{array}$ & $\begin{array}{c}-0.211^{* * *} \\
(0.0522)\end{array}$ & $\begin{array}{l}-0.238^{* * *} \\
(0.0939)\end{array}$ & $\begin{array}{l}-0.292^{*} \\
(0.168)\end{array}$ \\
\hline $99^{\text {th }}$ Priority Percentile & $\begin{array}{c}-0.236^{* * * *} \\
(0.0643)\end{array}$ & $\begin{array}{r}-0.330^{* * * *} \\
(0.0774)\end{array}$ & $\begin{array}{r}-0.488^{* * *} \\
(0.189)\end{array}$ & $\begin{array}{r}-5.193^{* * *} \\
(0.984)\end{array}$ \\
\hline Homesteads & $\begin{array}{r}-0.00399^{* *} \\
(0.00166)\end{array}$ & $\begin{array}{r}-0.00320^{*} \\
(0.00190)\end{array}$ & $\begin{array}{r}0.00345 \\
(0.00295)\end{array}$ & $\begin{array}{r}0.00159 \\
(0.00350)\end{array}$ \\
\hline Summer Flow & $\begin{array}{l}0.0000155^{* * * *} \\
(0.00000591)\end{array}$ & $\begin{array}{l}0.0000211^{* * *} \\
(0.00000636)\end{array}$ & $\begin{array}{r}0.0000354^{*} \\
(0.0000186)\end{array}$ & $\begin{array}{l}0.0000383^{* *} \\
(0.0000159)\end{array}$ \\
\hline Flow Variability & $\begin{array}{l}-0.000282 \\
(0.000252)\end{array}$ & $\begin{array}{r}-0.000609 \\
(0.00144)\end{array}$ & $\begin{array}{r}0.00189 \\
(0.00293)\end{array}$ & $\begin{array}{r}-0.00300^{*} \\
(0.00169)\end{array}$ \\
\hline Roughness & $\begin{array}{l}-0.000134 \\
(0.000120)\end{array}$ & $\begin{array}{l}-0.000111 \\
(0.000141)\end{array}$ & $\begin{array}{r}0.000368 \\
(0.000373)\end{array}$ & $\begin{array}{l}-0.000840 \\
(0.000746)\end{array}$ \\
\hline Acres Loamy Soil & $\begin{array}{r}0.00000849 \\
(0.0000132)\end{array}$ & $\begin{array}{r}0.0000125 \\
(0.0000205)\end{array}$ & $\begin{array}{r}0.0000630 \\
(0.0000433)\end{array}$ & $\begin{array}{l}-0.0000436 \\
(0.0000285)\end{array}$ \\
\hline Acreage Along Stream & $\begin{array}{r}-0.00000346 \\
(0.00000461)\end{array}$ & $\begin{array}{l}-0.00000743 \\
(0.00000823)\end{array}$ & $\begin{array}{c}-0.0000245^{*} \\
(0.0000146)\end{array}$ & $\begin{array}{r}0.0000101 \\
(0.0000107)\end{array}$ \\
\hline $\begin{array}{l}\text { Watershed Fixed Effects } \\
\text { Year Fixed Effects }\end{array}$ & $\begin{array}{l}\text { No } \\
\text { Yes }\end{array}$ & $\begin{array}{l}\text { Yes } \\
\text { Yes }\end{array}$ & $\begin{array}{l}\text { Yes } \\
\text { Yes }\end{array}$ & $\begin{array}{l}\text { Yes } \\
\text { Yes }\end{array}$ \\
\hline$N$ & 4756 & 4354 & 1206 & 937 \\
\hline
\end{tabular}


Table B5: Effects of Cooperation and Priority on Investment

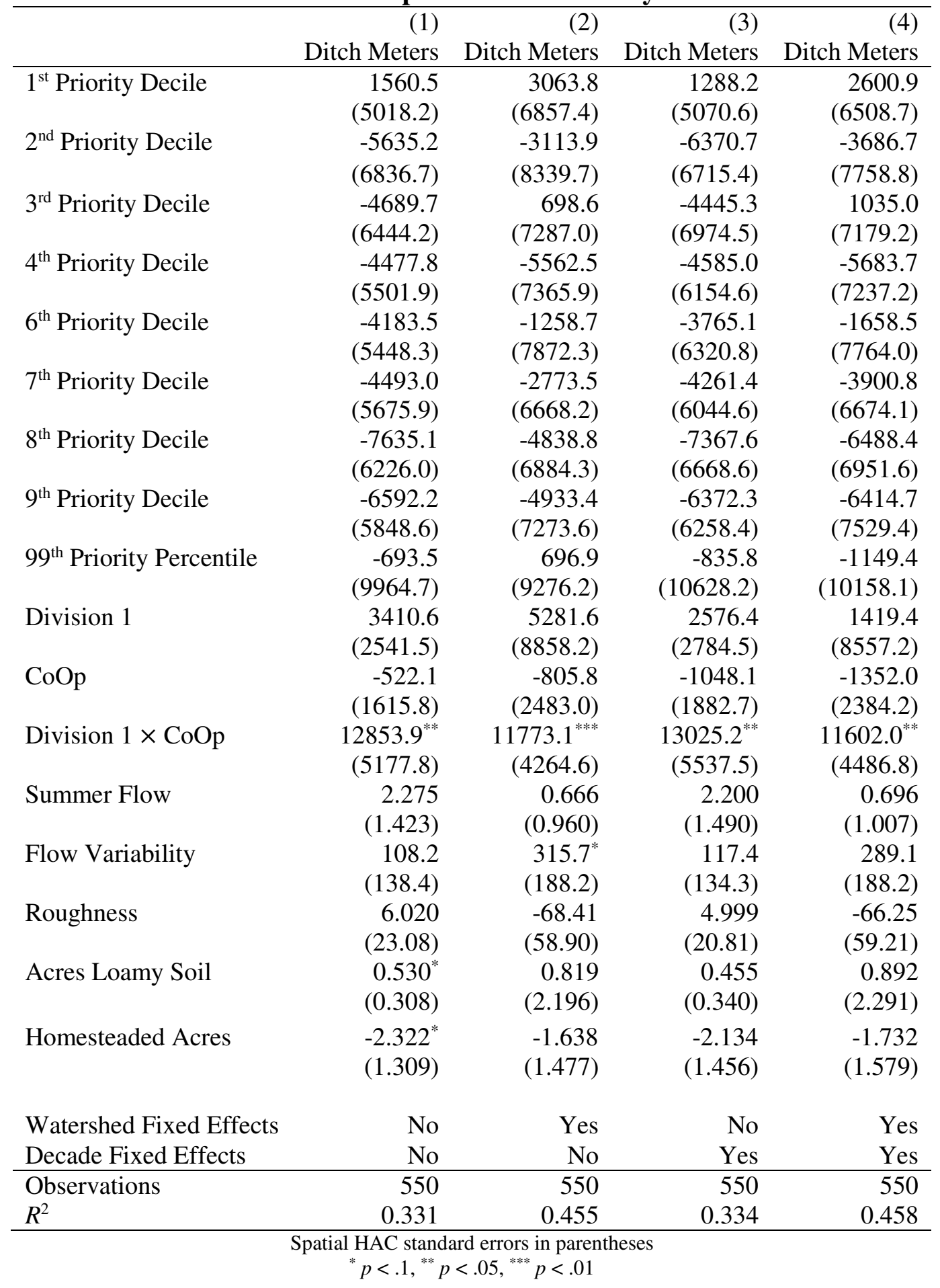


Table B6: Income Per Acre Pre-1960

\begin{tabular}{|c|c|c|c|c|c|c|}
\hline & \multicolumn{3}{|c|}{ Division 1} & \multicolumn{3}{|c|}{ Division 3} \\
\hline & (1) & (2) & (3) & (4) & (5) & (6) \\
\hline & Reduced & Irrigated & Income Per & Reduced & Irrigated & Income Per \\
\hline & Form & Acres & Acre & Form & Acres & Acre \\
\hline \multirow[t]{2}{*}{$\mathrm{CoOp}$} & $105.7^{* * *}$ & -251.7 & $81.04^{* * *}$ & -7.934 & -162.5 & -10.51 \\
\hline & $(28.60)$ & (165.4) & (28.94) & $(51.50)$ & $(230.5)$ & $(51.30)$ \\
\hline \multirow[t]{2}{*}{ Claim Size } & $1.139^{* *}$ & -3.963 & $1.162^{* *}$ & $0.664^{*}$ & -5.044 & 0.525 \\
\hline & $(0.468)$ & (3.819) & $(0.444)$ & $(0.354)$ & $(4.783)$ & $(0.547)$ \\
\hline \multirow[t]{2}{*}{ Summer Flow } & $0.0249^{*}$ & 0.0448 & 0.0133 & 0.0348 & -0.0726 & 0.0349 \\
\hline & $(0.0128)$ & $(0.0995)$ & $(0.0128)$ & $(0.0230)$ & $(0.117)$ & $(0.0237)$ \\
\hline \multirow[t]{2}{*}{ Flow Variability } & $-16.74^{* * *}$ & -41.80 & $-15.87^{* * * *}$ & -2.871 & -22.34 & -3.046 \\
\hline & (4.991) & (29.78) & $(5.036)$ & $(4.676)$ & $(21.96)$ & $(4.738)$ \\
\hline \multirow[t]{2}{*}{ Roughness } & -0.157 & 4.510 & -0.212 & -0.587 & -0.893 & -0.546 \\
\hline & (1.679) & (10.43) & (1.659) & $(0.645)$ & (4.196) & $(0.649)$ \\
\hline Percent Loamy & -0.638 & -3.239 & -0.244 & 155.0 & -234.3 & 155.0 \\
\hline Soil & $(2.953)$ & (7.928) & $(2.981)$ & $(147.5)$ & $(502.5)$ & (154.4) \\
\hline \multirow[t]{2}{*}{ Ditch Meters } & & $0.0723^{* * *}$ & $0.00208^{*}$ & & $0.206^{* * * *}$ & 0.00239 \\
\hline & & $(0.0101)$ & $(0.00117)$ & & $(0.0449)$ & $(0.00424)$ \\
\hline \multirow[t]{2}{*}{ Irrigated Acres } & & & 0.0109 & & & -0.00433 \\
\hline & & & $(0.0107)$ & & & $(0.00911)$ \\
\hline Homesteaded & $-0.0883^{* *}$ & $-0.433^{* *}$ & $-0.0873^{* *}$ & -0.0108 & 0.0797 & -0.0119 \\
\hline Acres & $(0.0356)$ & $(0.172)$ & $(0.0337)$ & $(0.0173)$ & $(0.0599)$ & $(0.0178)$ \\
\hline \multirow[t]{2}{*}{$1^{\text {st }}$ Priority Decile } & 43.19 & -60.89 & 19.98 & $158.0^{* * *}$ & 356.4 & $156.0^{* * *}$ \\
\hline & $(37.52)$ & (190.1) & (38.39) & $(63.24)$ & $(452.8)$ & $(64.16)$ \\
\hline \multirow[t]{2}{*}{$2^{\text {nd }}$ Priority Decile } & 11.28 & -450.8 & 19.50 & $136.5^{*}$ & 213.5 & $137.7^{*}$ \\
\hline & $(60.62)$ & (589.5) & $(55.27)$ & $(75.81)$ & $(304.0)$ & $(75.19)$ \\
\hline \multirow[t]{2}{*}{$3^{\text {rd }}$ Priority Decile } & $142.3^{* * *}$ & 626.8 & $116.1^{* *}$ & 82.67 & 106.5 & 84.03 \\
\hline & $(45.50)$ & (434.9) & $(50.68)$ & $(64.20)$ & $(316.5)$ & $(62.52)$ \\
\hline \multirow[t]{2}{*}{$4^{\text {th }}$ Priority Decile } & 35.01 & -27.43 & 27.69 & 132.0 & -103.8 & 130.1 \\
\hline & $(49.52)$ & $(218.3)$ & $(46.03)$ & $(96.47)$ & $(355.8)$ & $(96.95)$ \\
\hline \multirow[t]{2}{*}{$6^{\text {th }}$ Priority Decile } & 75.06 & 65.17 & $86.39^{*}$ & $126.2^{*}$ & 22.23 & $126.2^{*}$ \\
\hline & $(50.32)$ & $(265.8)$ & (47.11) & $(69.30)$ & $(340.2)$ & $(67.82)$ \\
\hline \multirow[t]{2}{*}{$7^{\text {th }}$ Priority Decile } & 153.8 & -107.9 & 143.5 & 121.1 & 758.3 & $133.3^{*}$ \\
\hline & (97.15) & $(312.2)$ & (101.3) & (74.07) & $(527.0)$ & $(75.88)$ \\
\hline \multirow[t]{2}{*}{$8^{\text {th }}$ Priority Decile } & $146.6^{*}$ & 119.6 & $149.9^{*}$ & 113.7 & -245.0 & 97.70 \\
\hline & (77.84) & (255.1) & $(75.92)$ & $(87.59)$ & $(687.2)$ & $(97.28)$ \\
\hline \multirow[t]{2}{*}{$9^{\text {th }}$ Priority Decile } & $218.7^{* * *}$ & -29.53 & $201.8^{* * *}$ & $190.0^{*}$ & -358.2 & $189.7^{*}$ \\
\hline & $(50.71)$ & (256.7) & $(51.83)$ & $(97.70)$ & $(350.1)$ & $(97.79)$ \\
\hline $99^{\text {th }}$ Priority & 106.5 & 15.38 & 96.04 & 76.97 & -541.8 & 69.67 \\
\hline Percentile & (99.42) & $(334.4)$ & $(94.73)$ & $(83.40)$ & $(601.3)$ & $(81.17)$ \\
\hline $\begin{array}{l}\text { Watershed Fixed } \\
\text { Effects }\end{array}$ & Yes & Yes & Yes & Yes & Yes & Yes \\
\hline Observations & 104 & & 104 & 104 & 161 & 160 \\
\hline$R^{2}$ & 0.949 & & 0.777 & 0.952 & 0.795 & 0.687 \\
\hline
\end{tabular}

$$
.05,{ }^{* * *} p<.01
$$


Table B7: Division 1 vs. 3

\begin{tabular}{|c|c|c|}
\hline & Division 1 & Division 3 \\
\hline Total Income & $\begin{array}{r}785,035.7 \\
(139,492.2)\end{array}$ & $\begin{array}{r}323,869.8 \\
(111,086.7)\end{array}$ \\
\hline Irrigated Acres & $\begin{array}{l}1,397.6 \\
(240.1)\end{array}$ & $\begin{array}{r}671.0 \\
(175.3)\end{array}$ \\
\hline Income Per Acre & $\begin{array}{r}561.9 \\
(17.8)\end{array}$ & $\begin{array}{l}523.4 \\
(26.9)\end{array}$ \\
\hline Claim Size & $\begin{array}{l}22.2 \\
(2.6)\end{array}$ & $\begin{array}{l}19.4 \\
(1.9)\end{array}$ \\
\hline Claim Date & $\begin{array}{r}-29,936.76 \\
(316.8)\end{array}$ & $\begin{array}{r}-29,163.77 \\
(354.3)\end{array}$ \\
\hline $\begin{array}{l}\text { Acres Loamy Soil } \\
\text { Near Stream }\end{array}$ & $\begin{array}{r}60.2 \\
(8.1)\end{array}$ & $\begin{array}{l}11.1 \\
(1.7)\end{array}$ \\
\hline Ditch Meters & $\begin{array}{l}13,522.2 \\
(1532.2)\end{array}$ & $\begin{array}{l}7,724.0 \\
(965.1)\end{array}$ \\
\hline $\begin{array}{l}\text { Potential Riparian Claims } \\
\text { Per Stream }\end{array}$ & $\begin{array}{r}50.42 \\
(72.93)\end{array}$ & $\begin{array}{r}28.43 \\
(47.46)\end{array}$ \\
\hline $\begin{array}{l}\text { Actual Appropriative Claims } \\
\text { Per Stream }\end{array}$ & $\begin{array}{r}3.11 \\
(9.77)\end{array}$ & $\begin{array}{r}2.48 \\
(9.58)\end{array}$ \\
\hline $\begin{array}{l}\text { Actual Homestead Claims Per } \\
\text { Township }\end{array}$ & $\begin{array}{r}84.68 \\
(146.38)\end{array}$ & $\begin{array}{r}11.1 \\
(41.37)\end{array}$ \\
\hline Number of Streams & 625 & 439 \\
\hline
\end{tabular}

